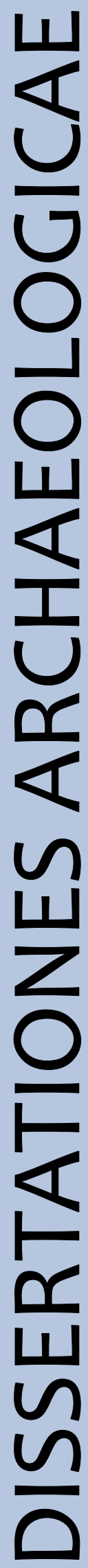

ex Instituto Archaeologico Universitatis de Rolando Eötvös nominatae
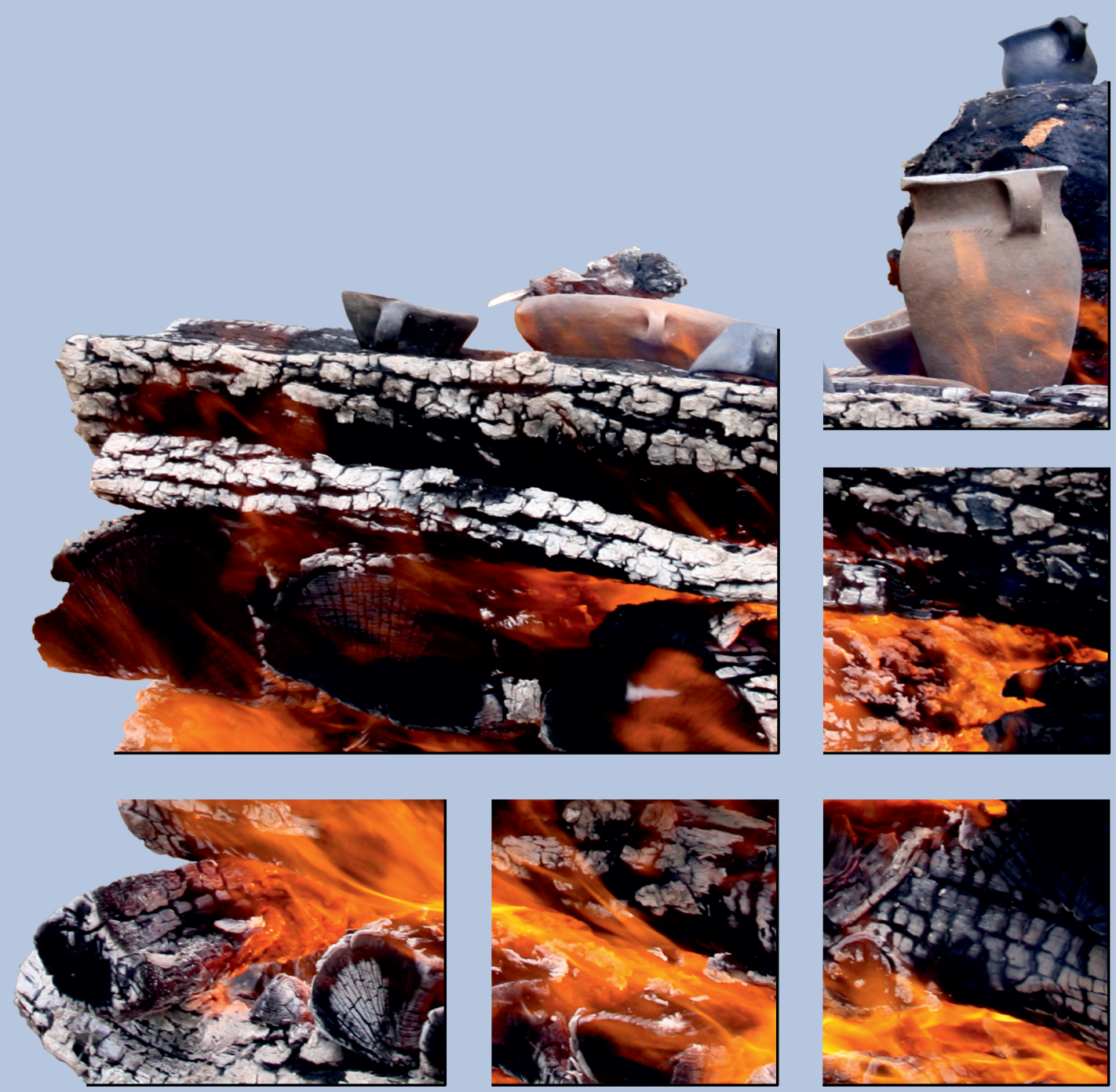

$$
\text { Ser。 3. No } 0_{0} \sigma_{0} \mid 2018
$$




\section{Dissertationes Archaeologicae ex Instituto Archaeologico}

Universitatis de Rolando Eötvös nominatae Ser. 3. No. 6.

Budapest 2018 


\section{Dissertationes Archaeologicae ex Instituto Archaeologico}

Universitatis de Rolando Eötvös nominatae Ser. 3. No. 6.

Editor-in-chief:

DÁvid BARTUS

Editorial board:

LÁsZló BARTOSIEWICZ

LÁSZLÓ BORHY

ZOLTÁN CZAJLIK

ISTVÁN FELD

GÁBOR KALLA

PÁL RACZKY

MiKLÓS SZABÓ

Tivadar Vida

Technical editor:

GÁBOR VÁcZI

Proofreading:

ZsófIA KondÉ

SzILVIA BARTUS-SzÖLLősI

Aviable online at http://dissarch.elte.hu

Contact: dissarch@btk.elte.hu

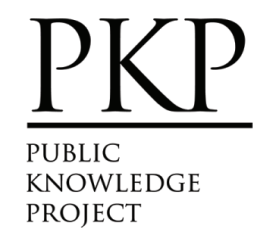

๑ E Eötvös Loránd University, Institute of Archaeological Sciences

Layout and cover design: Gábor Váczi

Budapest 2018 


\section{CONTENTS}

Zsolt Mester

In memoriam facques Tixier (1925-2018)

\section{ARTICLES}

Katalin SEBőK

On the possibilities of interpreting Neolithic pottery - Az újkökori kerámia értelmezési lehetőségeiről

András FüZESI - Pál RACZKY

Öcsöd-Kováshalom. Potscape of a Late Neolithic site in the Tisza region

Katalin SEBőK - Norbert FARAgó

Theory into practice: basic connections and stylistic affiliations of the Late Neolithic settlement at Pusztataskony-Ledence 1

Eszter Solnay

Early Copper Age Graves from Polgár-Nagy-Kasziba

László GuCsi - Nóra Szabó

Examination and possible interpretations of a Middle Bronze Age structured deposition

Kristóf FÜLÖP

Why is it so rare and random to find pyre sites? Two cremation experiments to understand the characteristics of pyre sites and their investigational possibilities

Gábor János TARBAY

"Looted Warriors" from Eastern Europe

Péter MogYoRós

Pre-Scythian burial in Tiszakürt

Szilvia JoHÁczi

A New Method in the Attribution? Attempts of the Employment of Geometric Morphometrics in the Attribution of Late Archaic Attic Lekythoi 
The Roman aqueduct of Brigetio

Lajos JuHÁsz

A republican plated denarius from Aquincum

Barbara HAJDU

Terra sigillata from the territory of the civil town of Brigetio

Krisztina HoppÁL - István VIDA - Shinatria AdHityatAma - Lu Yahui 461

'All that glitters is not Roman'. Roman coins discovered in East Java, Indonesia.

A study on new data with an overview on other coins discovered beyond India

\section{FIELD REPORTS}

Zsolt MESTER - Ferenc CSERPÁK - Norbert FARAGÓ

Preliminary report on the excavation at Andornaktálya-Marinka in 2018

Kristóf FÜLÖP - Denisa M. LÖNHARDT - Nóra SZABÓ - Gábor VÁcZI

Preliminary report on the excavation of the site Tiszakürt-Zsilke-tanya

Bence Simon - Szilvia JohÁcZI - Zita KIS

Short report on a rescue excavation of a prehistoric and Árpádian Age site near Tura

(Pest County, Hungary)

Zoltán CzAJlik - Katalin NovinszKi-Groma - László RupNIK - András BöDőcs - et al. 527

Archaeological investigations on the Süttö plateau in 2018

Dávid BARTus - László BORHY - Szilvia JoHÁczi - Emese SzÁMADó

Short report on the excavations in the legionary fortress of Brigetio (2017-2018)

Bence Simon - Szilvia JoháczI

Short report on the rescue excavations in the Roman Age Barbaricum near Abony

(Pest County, Hungary)

Szabolcs Balázs NAGY

Recent excavations at the medieval castle of Bánd 


\section{Thesis Abstracts}

Rita JENEY

Lost Collection from a Lost River: Interpreting Sir Aurel Stein's "Sarasvatī Tour" in the History of South Asian Archaeology

István VIDA

The Chronology of the Marcomannic-Sarmatian wars. The Danubian wars of Marcus Aurelius in the light of numismatics

Zsófia MASEK

Settlement History of the Middle Tisza Region in the $4^{\text {th }}-6^{\text {th }}$ centuries AD.

According to the Evaluation of the Material from Rákóczifalva-Bagi-földek 5-8-8A sites

Alpár Doвоs

Transformations of the human communities in the eastern part of the Carpathian Basin between the middle of the $5^{\text {th }}$ and $7^{\text {th }}$ century. Row-grave cemeteries in Transylvania, Partium and Banat 


\title{
Examination and possible interpretations of a Middle Bronze Age structured deposition
}

LÁsZLó GUCSI

Restorer, potter, illustrator

laszlogucsi@gmail.com
Nóra Szabó

Institute of Archaeological Sciences

Eötvös Lóránd University

szabonori91@gmail.com

\begin{abstract}
Ceramic depositions occur frequently in the Bronze Age throughout the Carpathian Basin, however, their characteristics and composition can vary between periods, cultures and regions. Thus there could be many theories and interpretations offered for the reasons behind hiding these depots. At the site of Budajeno", Hegyiszántók a structured deposition dating to the final phase of the Middle Bronze Age came to light, which is not only unique in terms of the quantity of the vessels but also of their quality, both on an intra-site level and from the perspective of the Hungarian Middle Bronze Age. The aim of this paper is to present a complex and multi-faceted analysis, which helps not only to understand the possible reasons behind the concealment of the vessels, but also to offer an interpretation for the chain of events in which they could have played a central role. Besides the examination of the quantity and the cultural characteristics of the vessels, traces of use-wear, along with the phenomena of secondary burning and deliberate fragmentations are also discussed.
\end{abstract}

\section{Introduction}

The single-layer site of Budajenő, Hegyi-szántók, situated in the eastern regions of the Zsámbék Basin at the foot of the Buda Hills (Fig. 1), was already assigned to the Middle Bronze Age by the Hungarian Archaeological Topography survey. ${ }^{1}$ The dating was further supported by excavations carried out in 2002-2003, prior to the construction of the Hilltop II housing estate within the administrative boundaries of Budajenő. ${ }^{2}$ The rescue work was conducted in eight trenches within which 862 domestic features associated with the Vatya III - Koszider period were unearthed in an area of $220 \times 140$ meters. ${ }^{3}$ Beside a number of refuse pits, a ditch was also identified in the northern section of the excavation area (which was investigated in slots), presumably dating to the Middle Bronze Age as well, and could have surrounded the central part of the settlement (Fig. 2). ${ }^{4}$

The site, considering its size and location, could have played an important role in the Middle Bronze Age. The settlement was established on a hilltop overlooking the gently undulating landscape of the Zsámbék Basin, affording it a strategically advantageous position. ${ }^{5}$ Further-

1 DinnYÉs et al. 1986, 40. Site number: $2 / 9$.

2 REPISZKY 2004a, 184; REPISZKY 2004b, 168.

3 Some of the domestic material discovered from the settlement was written up by Nóra Szabó in her MA dissertation (SzABó 2018).

4 The area of excavation did not include this highest part of the hilltop.

5 Previously, the site has been classified as a fortified settlement (DINNYÉs et al. 1986, 40; REPISZKY 2004a, 184; SzeverÉnyi - Kulcsár 2012, 295, Tab. 1; JAEger et al. 2018, Fig. 1), and given its hilltop position it could be compared to sites situated west of the Danube (SzEverénYi - KulCsÁr 2012, 293-320; KIss 2012, 211-215). 
more, the hilltop was (and still is to a certain extent) surrounded by the marshy wetlands of the Budajenő Stream's water-catchment area. ${ }^{6}$

Feature 80 was discovered in the mid-section of Trench II, located in the outer, horizontal area of the settlement, a little farther away from the rest of the features. The amount of ceramics unearthed from the feature, ${ }^{7}$ both in terms of quantity (the number and weight of sherds) and quality (the number of sherds displaying signs of secondary burning, diagnostic pieces or complete vessels) was unusually high not only on an intra-site level, but also from the perspective of the Hungarian Middle Bronze Age. ${ }^{8}$

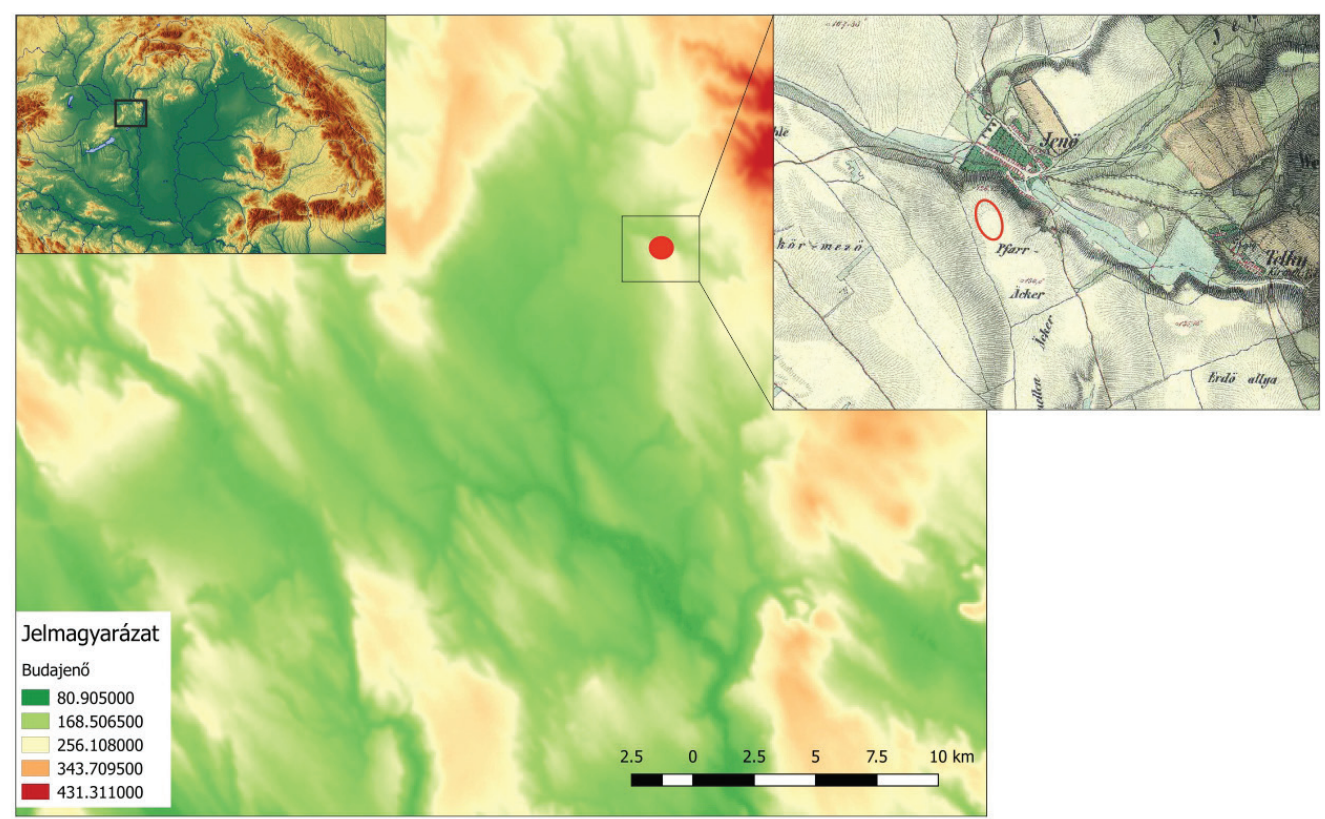

Fig. 1. The location of the single-layer site of Budajenő.

\section{Feature 80 and its contents}

Following the removal of the upper humus layer, but prior to the excavation of the feature itself, a large amount of ceramic fragments were observed on the surface of which the majority was red in colour, showing signs of secondary burning. The round feature measured approximately $120 \mathrm{cms}$ in diameter and about $60 \mathrm{cms}$ in depth (presumably). ${ }^{9}$ Besides the numerous fragmented pieces, the documentation described unusually large-sized sherds, complete storage vessels in an upright position and other smaller ceramics. ${ }^{10}$

Initially, the documentation listed 1192 pieces of ceramic fragments, weighing $68.5 \mathrm{kgs}$. However, following the restoration of the material, ${ }^{11}$ out of the 1192 fragments, 72 complete vessels

6 Based on the Second Military Survey of the Habsburg Empire (1819-1869).

7 Apart from sherds of ceramic vessels, a small number of other artefacts was also documented from the feature such as a fragment of a loomweight, a piece of stone and a shell.

8 SzABó 2018, 66-68.

9 Unfortunately, the original drawing of the feature was lost, and measurements were approximated based on the photographic record.

10 Regrettably, neither the complete vessels' exact position, nor the distribution of other fragments were recorded during the excavation.

11 The restoration of the material found in Feature 80 was carried out by László Gucsi. 


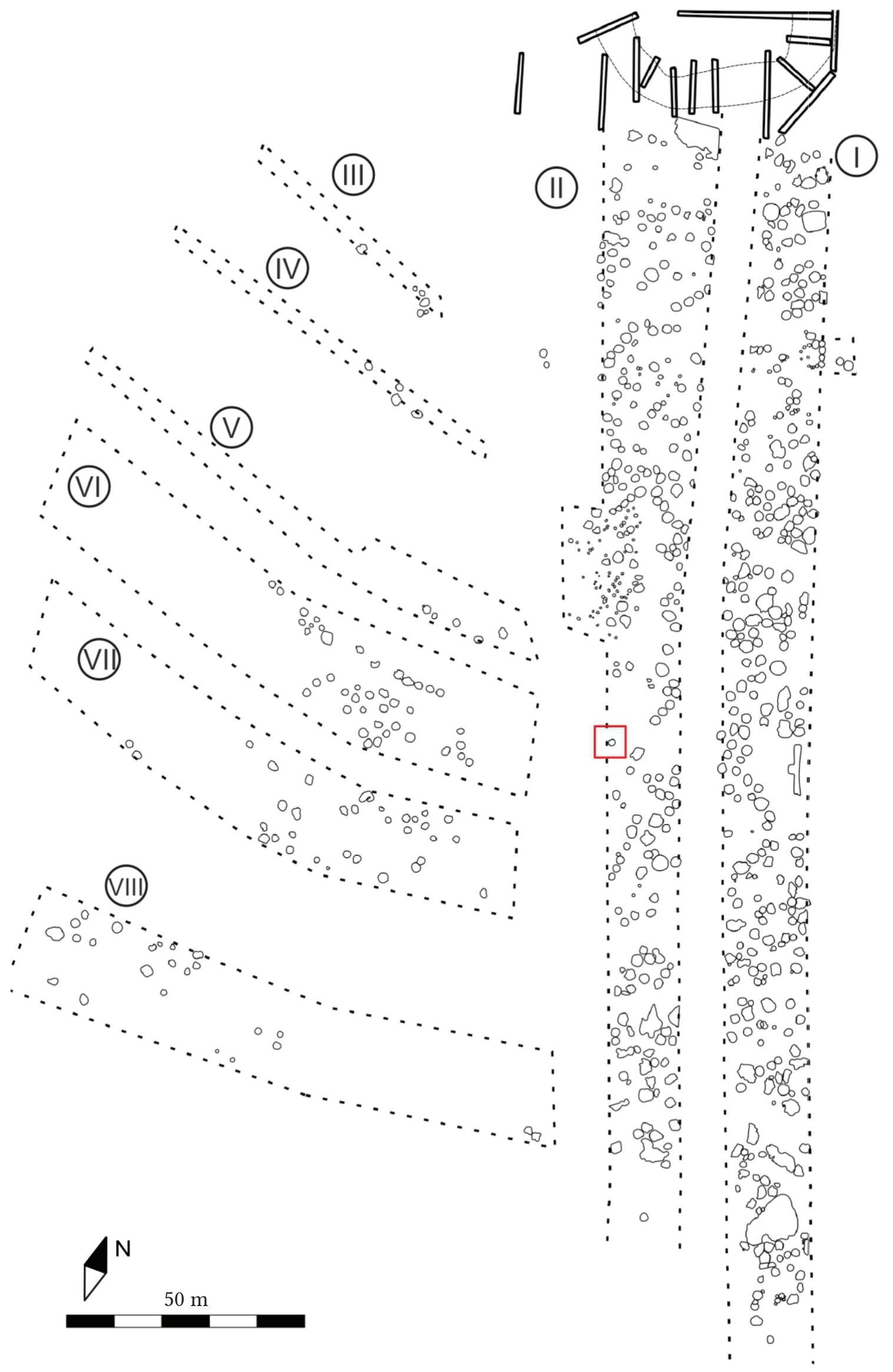

Fig. 2. The map of the settlement and the location of Feature 80. 
(or partial vessels with diagnostic features) could be reconstructed from 954 fragments. ${ }^{12}$ The examination of the 72 complete or partially complete but diagnostic vessels, together with the rest of the ceramic fragments (238 pieces), altogether 310 ceramic units, concluded that in 233 cases signs of secondary burning were present. ${ }^{13}$
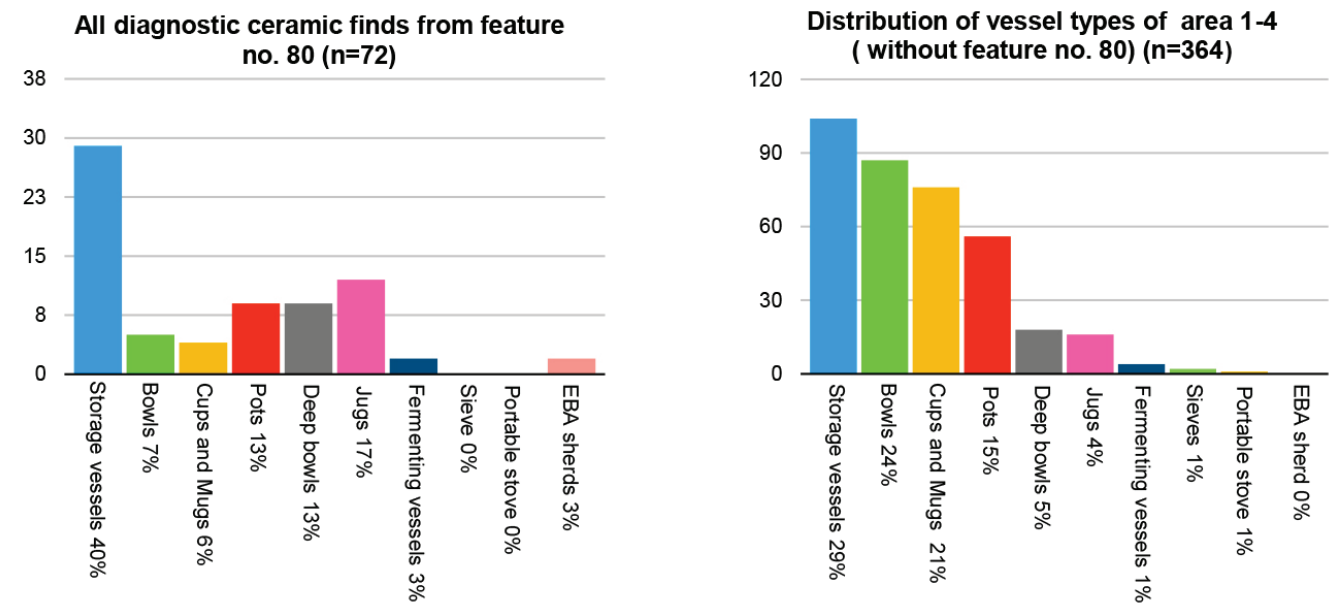

Fig. 3. Comparative diagram of the distribution of the vessel types between Feature 80 and other areas of the settlement.

\section{The distribution of vessel types}

Comparing the distribution of vessel types recorded in Feature 80 with all the vessel types recovered from the settlement as a whole, the following observations can be made (Fig. 3). In both cases, storage vessels were the most numerous, but in Feature 80 their number was slightly higher. The ratio of cooking pots was nearly equal, while the ratio of deep bowls and fermenting vessels was three times, and jugs four times higher in Feature 80 than recorded in the entire settlement. Cups and bowls occurred in lower numbers in the feature. The relative amounts suggest that the low representation of certain vessel types (cups and bowls) could be associated with personal consumption, while over-represented types (such as jugs, deep bowls, storage vessels and fermenting vessels) could relate to communal consumption practices (Fig. 4).

\section{Ceramic types influenced by the Transdanubian Encrusted Pottery complex}

It is intriguing that while ceramics of the Transdanubian Encrusted Pottery Culture were discovered in a number of features at the site ${ }^{14}$ these artefacts were lacking among the contents of Feature 80. This is interesting, since import ceramic pieces produced by the Transdanubian Encrusted Pottery complex are normally among the highest represented vessels, suggesting intense trading relationships between the two communities ${ }^{15}$ which also implies that these

The occurrence of large amount of diagnostic ceramic fragments was not unusual within the context of this particular settlement; one or two pits contained as much as 50-60 pieces of diagnostic sherds, however, such an outstandingly large number of complete or partially complete vessels was only recorded in Feature 80.

13 SzABó 2018, 126.

14 Szabó 2018, 1. Tábla 13, 2. Tábla 5, 17. Tábla 1.

15 P. Fischl et al. 1999, 118. Footnote 106; P. FisCHL - KISS 2015, 50-51; FeKETE 2005, 45. 
imports could have been associated with high prestige-values in the Vatya context. ${ }^{16}$ Their absence in Feature 80 could perhaps be the result of deliberate selection. ${ }^{17}$ However, there were three vessels in the assemblage which demand slightly more attention: these artefacts display characteristics typical of the Transdanubian Encrusted Pottery complex such as the particular decoration technique, the proportions of vessels, or the thinness of vessel-walls. ${ }^{18}$ We would suggest that these elements represent close links between the two pottery-making traditions. ${ }^{19}$ Similarly, a design resembling a moustache on a fermenting vessel (Vessel 72 Fig. 38.1) could be interpreted as the representation of analogous bronze ornaments of the Transdanubian Encrusted Pottery Culture. ${ }^{20}$ Vessels recovered from sites of the Vatya Culture are generally decorated with a plastic crescent symbol that is likely to be the depiction of a characteristic Vatya bronze pendant. ${ }^{21}$

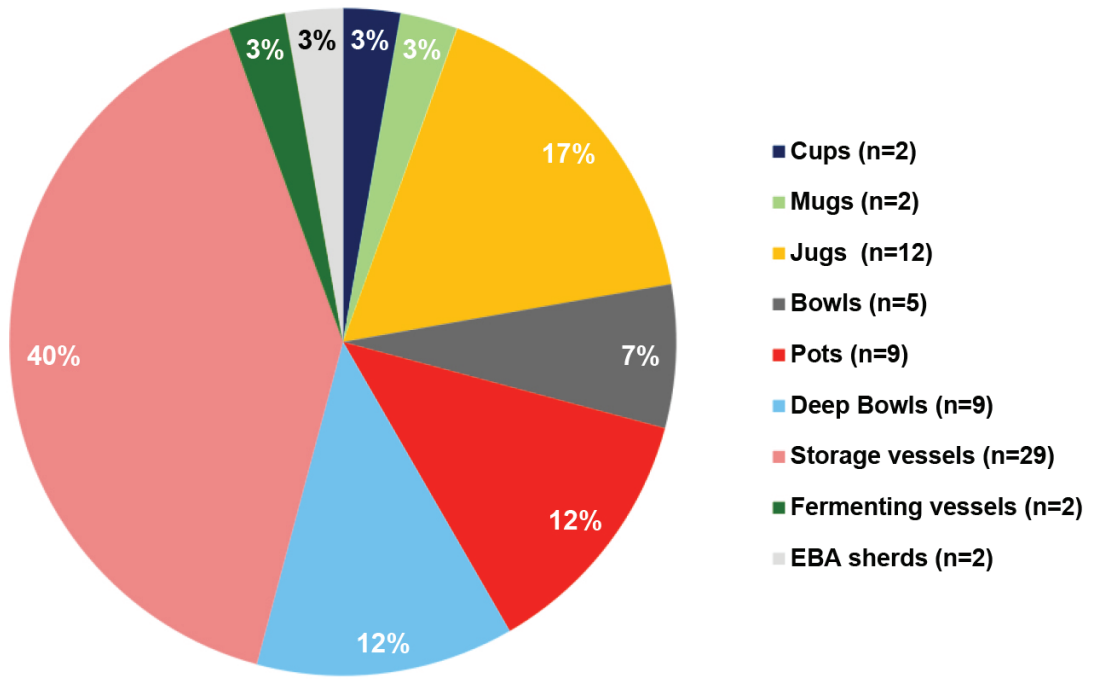

Fig. 4. Distribution of vessel types in Feature 80.

\section{Vessels occurring in pairs}

Among the assemblage there were two pairs of 'twin' vessels - the shape and design of these ceramics suggests that they were produced by the same potter: Vessel 5 - Fig. 11.b, 20.1, Vessel 6 Fig. 20.2, Fig. 39.2 and Vessel 42 - Fig. 18.1, Fig. 41, Vessel 43 - Fig. 19.2. Further eight vessels could also be considered in this category, ${ }^{22}$ but in these cases the vessels were either too fragmented or had fewer diagnostic features in order to be clearly identified as vessels made by the same potter. ${ }^{23}$

16 Kiss 2011, 212-214

17 Since most Vatya sites that yielded large amounts of ceramic material had also had a significant number of import vessels present, it is intriguing why import pieces from the neighbouring Middle Bronze Age groups are lacking or occur only in very small numbers among the material of Budajenő, Hegyi-szántók.

18 Vessel 4 - Fig. 17.6, Vessel 7 - Fig. 11.a, 21.1, Vessel 70 - Fig. 36.1.

19 KovÁcs 1978, 220; P. Fischl et al. 1999, 117-118; Kreiter 2006, 158-159.

20 Further two similar pieces are known from other features of the settlement (SzABó 2018, 6. Tábla 3, 15. Tábla 4.)

21 Poroszlai 1988, Fig. 7; P. Fischl et al. 1999, Fig. 23. 3-5, Fig. 34. 4; Vicze 2011, Pl. 103. 5, Pl. 104. 2, Pl. 186.2.

22 Vessel 17 - Fig. 17.4, Vessel 18 - Fig. 17.5; Vessel 54 - Fig. 23.1, Vessel 55 - Fig. 25.1; Vessel 33 - Fig. 29.2, Vessel 34 - Fig. 29.1; Vessel 38 - Fig. 36.2, Vessel 39 - Fig. 30.1.

23 The identification of such vessels was straight forward in cases when the vessel was complete (or nearly complete), had a rich and unique design, or a complex shape. 
The examination of 'twin' vessels from Feature 80 revealed that one member of the 'twin' had a more spherical, while the other, a more angular shape. Among the jugs, Vessel no. 6 was slightly more spherical, while among the storage vessels, Vessel 42 (Fig 18.1) had more rounded characteristics based on the belly-curve, and - in the case of the jug - the lack of definition between the shoulder and the neck.

This kind of formal duplication fits in with recent theories advocating that ceramic vessels in Bronze Age cemeteries (mainly urns) resemble the individual buried in them. ${ }^{24}$ There are several anthropomorphic vessels known from Vatya territories clearly depicting recognisable features of gender. ${ }^{25}$

\section{Chronology of vessel types}

According to the typo-chronological assessment of the ceramic material the Budajenon settlement dates to the later period of the Middle Bronze Age, to the Vatya III - Koszider phase. The formal characteristics and decoration of the vessels recovered from Feature 80 place the contents clearly to the Koszider period. ${ }^{26}$ Large storage vessels (urn-type vessels) demonstrate the typical characteristics of this later chronological phase: the vessels are divided into three equal parts (neck, upper body, lower body), with strongly funnelled, cylindrical or everted rims.$^{27}$ Apart from simple, incised motifs on the external surfaces, plastic ornamentation, channelling and complex panel-designs also occur which, typically to the Koszider period, are placed below the shoulder or above the belly-curve. ${ }^{28}$ Another group of storage vessels, deep bowls can also be associated with this later period based on the small-sized knobs applied onto the shoulder. ${ }^{29}$

The decoration of cooking pots indicates a later chronological phase as well, such as pointed knobs attached to the rim or diagonal ribs placed right below the mouth. ${ }^{30}$ In some cases, it could be observed that the neck and shoulder of cooking pots were not joined in the usual ' $\mathrm{S}$ ' shape, but formed an angle with the cylindrical or funnelled neck. This characteristic occurs on a pot Vessel 31 (Fig. 35.4) and on another pot, Vessel 30 (Fig. 35.1), with an additional wide, vertically notched rib running under the rim.

Bowls with rims that form a ' $\mathrm{T}$ ' in cross-section and bowls with small knobs on the rims further support the dating of the assemblage to the Koszider period. ${ }^{31}$ The bowls of Vessel 17 (Fig. 17.4) and Vessel 18 (Fig. 17.5) represent a different type which can be found both in the cemetery of Dunaújváros-Duna-dúlő and at the settlement of Alpár during the Koszider phase. ${ }^{32}$

24 Szabó - Hajdu 2011, 97-104; Szeverényi 2013, 224-225; Wieszner 2016, 21.

25 Kovács 1988, Fig. 5. 2-3; Poroszlai 1992, 153, 155. Abb. 109-110; Poroszlai 2000a, 52, Pl. XII; Kreiter 2005, Pl. 4-5; SZEVERÉNYI 2013, 224-225.

26 RePisZky 2004a, 184; REPISZKy 2004b, 168; SzABÓ 2018, 134.

27 BónA - NovÁKi 1982, 67; Vicze 2011, 121, 125, 132.

28 BónA 1975, Taf. 39. 6, Taf. 42. 1, Taf. 50. 5, Taf. 62. 6; Vicze 2011, Pl. 163. 6, Pl. 171. 9, Pl. 184. 8, Pl. 187. 11, Pl. 188. 6.

29 BónA - NovÁKi 1982, 67, 70-71; P. Fischl et al. 1999, 108.

30 Marosi 1930, 71. kép 1; BónA - Nováki 1982, 67, 69-70, T. VI. 4, T. XVII. 7-10; Lőrinczy - Trogmayer 1995, 22. kép 16; P. Fischl et al. 1999, 107, 21. kép 1, 36. kép 2, 41. kép 5, 46. kép 3; Poroszlai 2000a, Pl. X. 1; JAEGER - KulcsÁr 2013, Fig. 7. 3.

31 BónA 1975, Taf. 49. 2, Taf. 50. 2-3, Taf. 51. 6, Taf. 65. 3; BónA - NovÁki 1982, T. VI. 3, T. VIII. 8; P. Fischl et al. 1999, 4; VICZE 2011, 129, 135, Pl. 170. 4, Pl. 171. 2, Pl. 182. 11. BóNA - NovÁki 1982, 210, X. 7; Vicze 2011, Pl. 221. 1. 
Although these pieces are different in their decoration, the design was applied to a short and curved shoulder that is absent on bowls of the previous period. ${ }^{33}$

The ansa lunata handles are also typical characteristics of the Koszider phase. The highly burnished and richly decorated jugs represent the high-end of fine wares thus it is rarely possible to find their direct analogues in other assemblages. ${ }^{34}$ However, direct formal examples of the two fine jugs from Feature 80 are known from Lovasberény-Jánoshegy, Cegléd-Öreghegy and Kakucs-Balla-domb. ${ }^{35}$ Impressed lenticular and smoothed garland motifs appear frequently on many vessel types, which also suggests the dating of the assemblage to the latest period of the Middle Bronze Age. ${ }^{36}$

Apart from the eclectic 'mix' of decoration styles originating from the ceramic traditions of neighbouring groups (this on its own represents a new element in the Vatya design repertoire), the variation on reflectional and rotational symmetries is also characteristic in this phase. Vessel forms that were based on quarters, were divided even further (into eights in most cases) in the Koszider period. Symmetrical variations are often being represented on a single vessel: while the placement of knobs follow the traditional quarterly division, the handle(s) were applied in different angles, not aligned with, but placed in between two knobs. (Vessel 42 - Fig. 18.1, Vessel 39 - Fig. 30.1). ${ }^{37}$ There are also vessels where their attachments were divided into axes of eights while the ornamentation around the handles were strongly emphasized (Vessel 7 - Fig. 11.a, Fig. 21.1). ${ }^{38}$

It should be noted, that based on their formal characteristics, two fragments can be assigned to the Early Bronze Age (Vessel 22 - Fig. 38.2, Vessel 23 - Fig. 38.3). ${ }^{39}$

\section{Levels of potters' skill}

The vessels not only represent a variety of typological categories but also reflect their makers' skill, according to which the vessels could be further classified.$^{40}$ In this study, the following categories were drawn up based on the craftsperson's skill: ${ }^{41}$

\section{Level 1 - beginner I}

The vessels in this category come in simple forms and small sizes with thick walls and often uneven surfaces. They do not seem to fit into the ceramic repertoire of any particular culture. The vessels suggest that their producers encountered significant difficulty when handling the clay and shaping the objects. It is highly likely that in prehistoric societies the producers of such vessels were young children up until the age of seven (Infans I-II). ${ }^{42}$

VICZE 2011, Pl. 194. 1, 10, Pl. 196. 1, Pl. 199. 8.

BóNA - NovÁKi 1982, 76.

Bóna 1975, Taf. 49. 8, Taf. 44. 5; JAeger - KulcsÁr 2013, Fig. 6. 1.

BónA - NovÁki 1982, T. II. 23; EndRődi - Gyulai 1999, Fig. 8. 5; Poroszlai 2000a, Pl. IX. 1, Pl. XI. 23; VÁczi 2003, 6. kép. 4; VÁCZI 2004, 9. kép. 1.

Vicze 2011, Pl. 180. 4, Pl. 193. 2.

VICZE 2011, Pl. 189. 8.

KulCsÁr 2009, 109, Fig. 21.

BUdDEN - SOFAER 2009, 7-8; GuCsI 2009, 454; FÜLÖP 2016, 124-126.

The definition of these five categories is based on the observations of László Gucsi.

Kreiter 2007a, 154. 


\section{Level 2 - beginner II}

Vessel surfaces are generally uneven, rims are undulating, handles are often irregular and their curve is unbalanced. The walls are either too thick or too thin, or, in some cases, both. The decoration is irregular, outlines are variable, the positioning is unusual. However, these vessels do resemble some widely used examples, or at least, the prototype is recognisable. Asymmetric, uneven shapes also occur. It is possible that these vessels were also produced by children, or young adolescents (Infans II - Juvenis).

\section{Level 3 - intermediate}

Vessels are similar to the ones in the beginner II category, but reflect slightly better potting skills. Some pieces do conform to particular typological categories. However, the proportions of vessel parts can still be irregular, resulting in - especially among larger storage vessels - in slumped, warped shapes (Juvenis - Adultus).

\section{Level 4 - advanced}

Vessels classified in this category are well-proportioned, with neat but not always well-structured decoration. The rims are slightly undulating in some cases, but not noticeably. Vessel walls are even and functional.

\section{Level 5 - master}

The rims, walls, decoration are all neatly and symmetrically carried out, on a well-proportioned vessel.
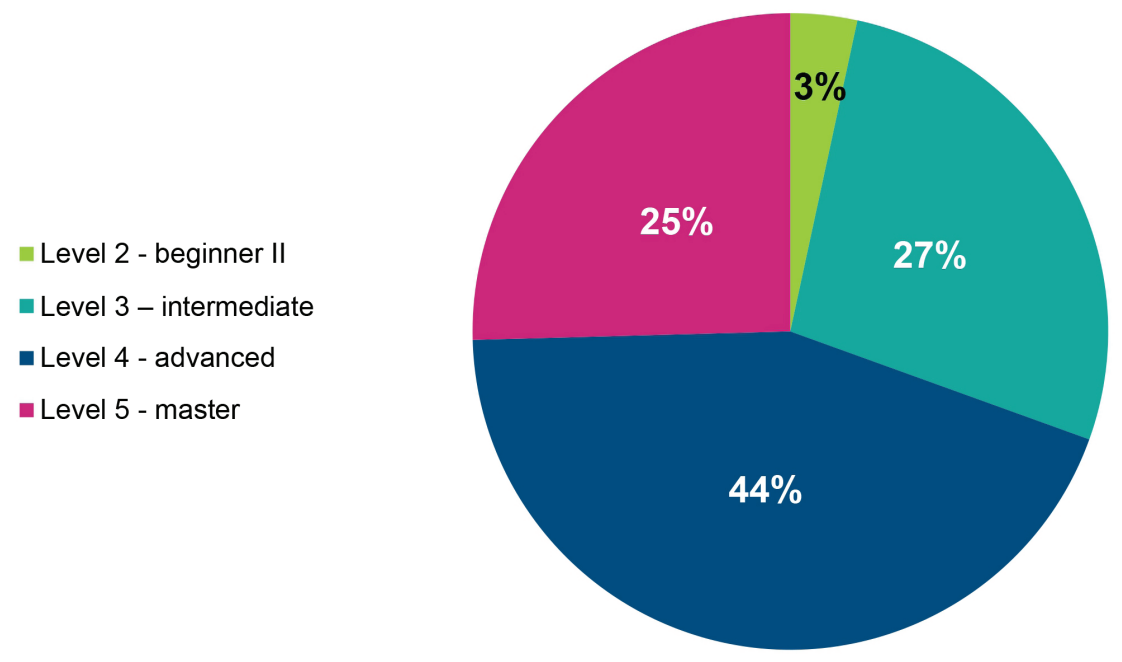

Fig. 5. Distribution of levels of potters' skills in Feature 80.

From Feature 80 two vessels can be categorised into the beginner II group, representing 3\% of the 58 vessels that could be considered for the examination of skill (Fig 5). One of them is an oval bowl (Vessel 21 - Fig. 17.2) while the other is a jug (Vessel 13 - Fig. 24.3). 27\% of the vessels are assumed to be the products of potters of intermediate skill. $44 \%$ of the artefacts were presumably produced by advanced potters, while $25 \%$ of the vessels were the work of master craftspeople (Fig. 5). Considering the execution of vessel types as a whole, cooking pots, deep bowls and storage vessels appear to reflect similar distributions of potters' skill. (Fig. 6). In the case of jugs, the products of Level 3 - intermediate potters seem to be represented in 
a higher than average number, while the products of Level 4 - advanced potters were lower. Works of Level 5 - master potters, however, appear to correlate to the average number of pots produced by master potters in the assemblage as a whole. It is notable that the fermenting vessel was the work of a master craftsperson.

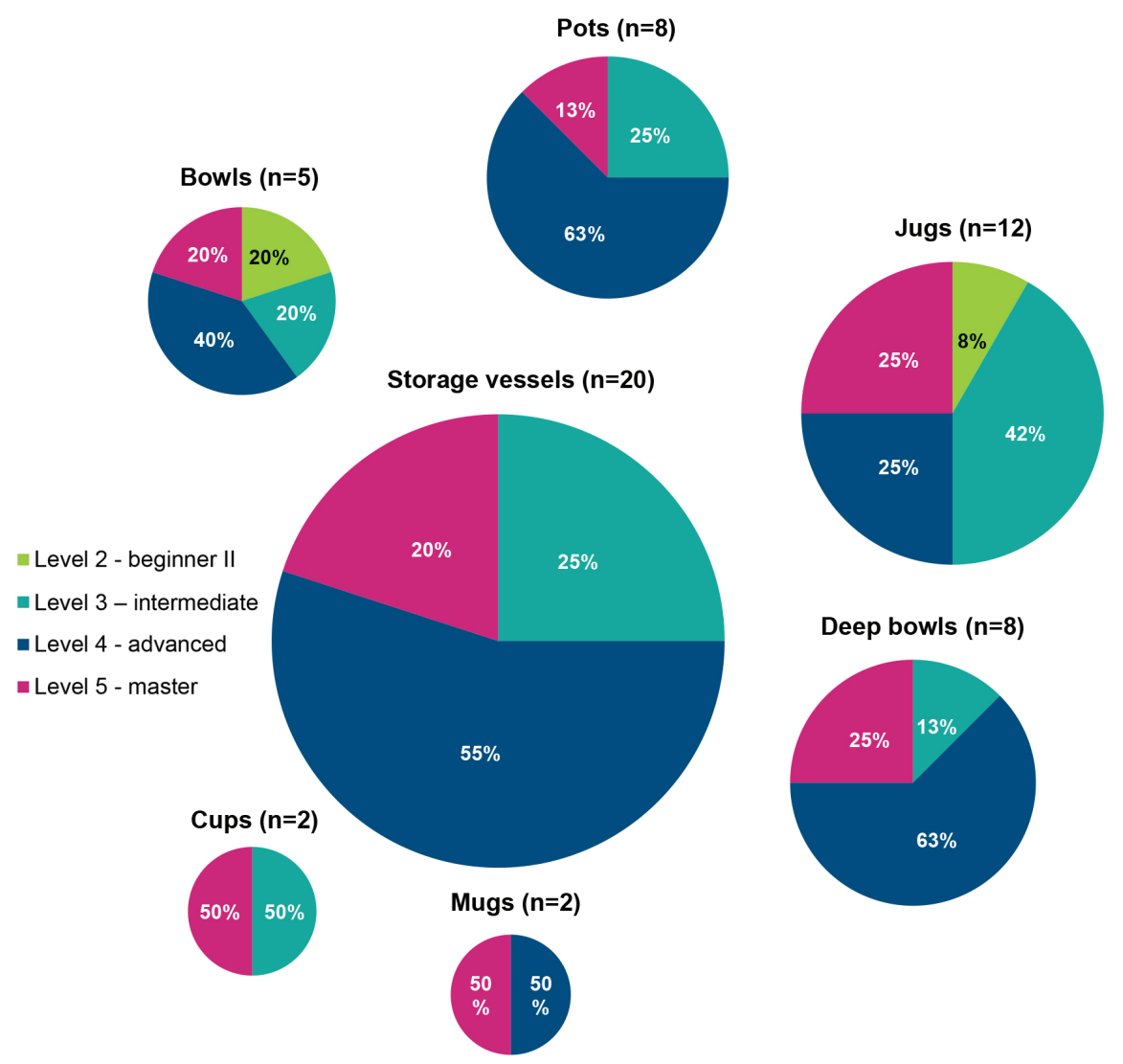

Fig. 6. Distribution of levels of potters' skill according to vessel types.

Such categorization of potters' skill is not yet a well-established approach ${ }^{43}$ therefore a comparable analysis can only be carried out within a limited framework. Similar examinations conducted on the ceramic material of the Copper Age Budakalász cemetery show that $4 \%$ of the vessels were produced by Level 1 potters, and $5 \%$ by Level 2 potters - thus $9 \%$ of the vessels were the works of low-skilled craftspeople. ${ }^{44}$ It is intriguing that from Feature 80 only $3 \%$ of vessels were produced by Level 2 potters and none of them by Level 1 potters.

It is interesting that the formal characteristics of a storage vessel (Vessel 49 - Fig. 24.4) imply a highly-skilled craftsperson, while its slightly negligent ornamentation suggests that the decoration of the vessel was done by a less-experienced potter. The fact that multiple craftspeople worked on a single vessel is not without example. ${ }^{45}$ These cases imply that a highly-skilled potter was not concerned about the decoration being carried out by someone less-experienced; an attitude that has been described by numerous ethnographic accounts. ${ }^{46}$ Especially, considering that the building and shaping of the large storage vessel could have

43 Kristóf Fülöp is working on developing such methodology for his $\mathrm{PhD}$ thesis.

44 Gucsi 2009, 455. Since these examples represent different time periods, they are not suitable for a more detailed comparison, standing here only as think-pieces.

45 BudDEN - SOFAER 2012, 123, Fig. 12. 8.

46 Michelaki 2008, 373-374; Gosselain - Livingstone Smith 2005, 40, 44-45. 
taken at least four hours, while the rather simplistic design could have been done in about ten minutes (even by a low-skilled person). Additionally, towards the base of the vessel an impression of some kind of textile was documented in a small patch, which is quite rare in this cultural context (Fig. 9).

It is notable that three vessels had impressions left by grains on their surfaces; ${ }^{47}$ a phenomenon that has been recorded at a number of other sites of different time periods. ${ }^{48}$ The exact explanation of this occurrence is unknown, but the distribution of grain impressions and the fact that some of them were partially embedded in the vessel surface prior to firing indicates that their presence was not accidental. This is further supported by two grain impressions documented on the fermenting vessel recovered from Feature 80.
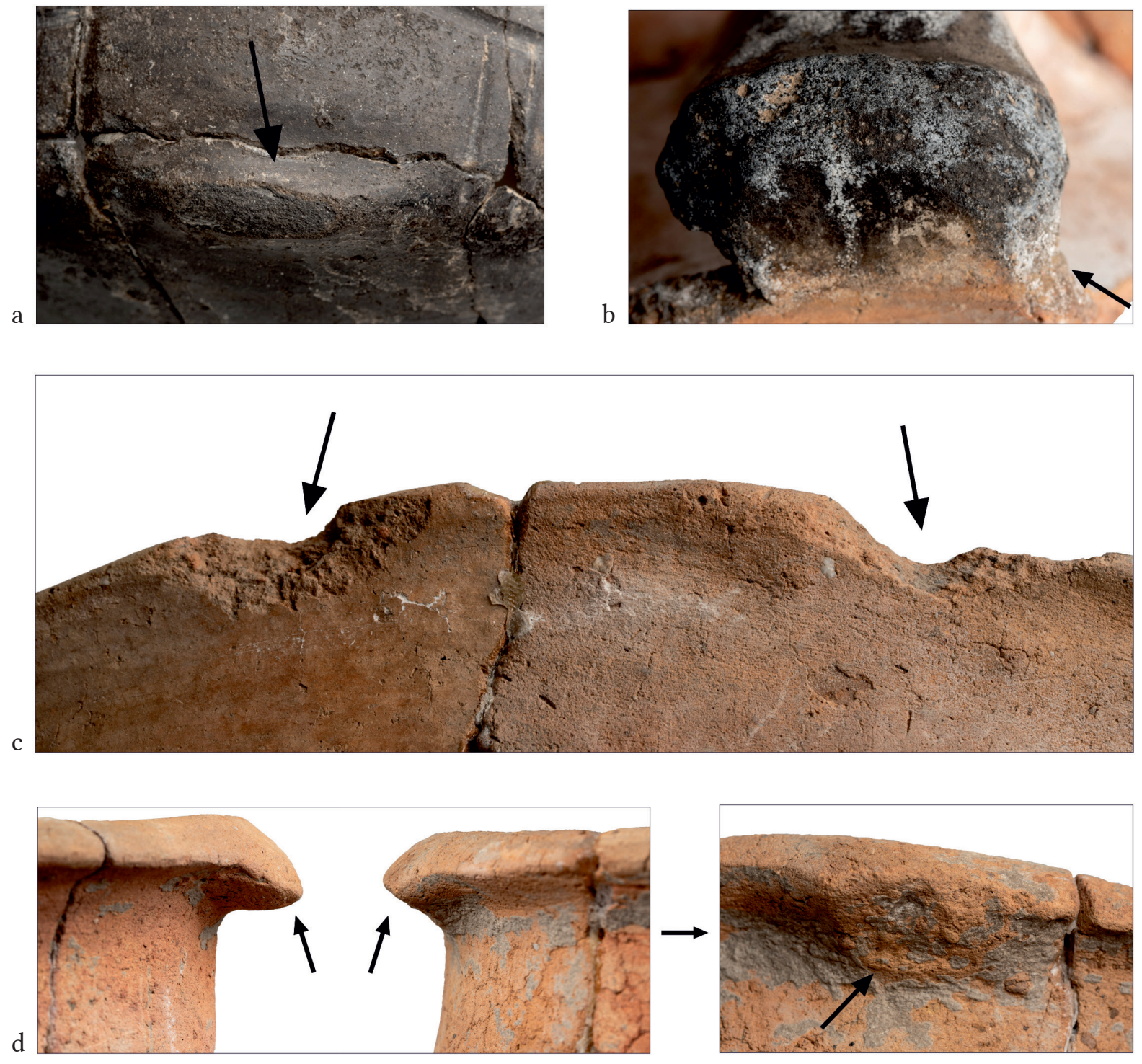

Fig. 7. Use-wear traces on vessels from Feature 80. a - worn surface on Vessel 7, b - abraded fracture surface on Vessel 57, c - chipped rim on Vessel 70, d - intact and broken knobs on Vessel 24.

47 Vessel 42 - Fig. 18.1, Vessel 72 - Fig. 38.1,16, Vessel 16 - Fig. 12.b, Fig. 19.4.

48 BONDÁr - RACZKy 2009, Pl. CXXVIII, 335/2; GHERdÁn et al. 2010, 94, 5. ábra; SÁnTA in print. Gabriella Kulcsár and László Gucsi also observed a number of grain impressions on Early Bronze Age vessels from Pécs-Nagyárpád-Dióstető site, excavated by Gábor Bándi. 


\section{Use-wear and the 'value' of vessels}

The examinations carried out on the material concerning both the level of potters' skill and use-wear imply that the majority of the ceramics recovered from Feature 80 were the works of advanced or master craftspeople. Also, there was very little use-wear detected on the pieces suggesting that the assemblage might have represented high prestige value. This, however, did not mean that only intact and unscathed vessels produced by master potters were selected for the assemblage. For example, for contemporary urn burials, items held in less esteem were a preferred choice. ${ }^{49}$

In the cases of two deep bowls, the badly eroded internal surfaces suggest acidic content at some stage..$^{50} \mathrm{~A}$ jug (Vessel 7 - Fig. 7.a, 8.a, 11.a, 21.1) was continued to be used even after breakage. A fragment of a storage vessel (Vessel 60 - Fig. 25.3) - based on the structure of fragmentation - is likely to have already been broken before the deposition took place. Two body sherds $\mathrm{s}^{51}$ belonged to vessels used intensely before breakage and prior to being deposited in the pit. Furthermore, there were also examples of use-wear recorded on the rims of several vessels (Vessel 70 - Fig. 7.c).
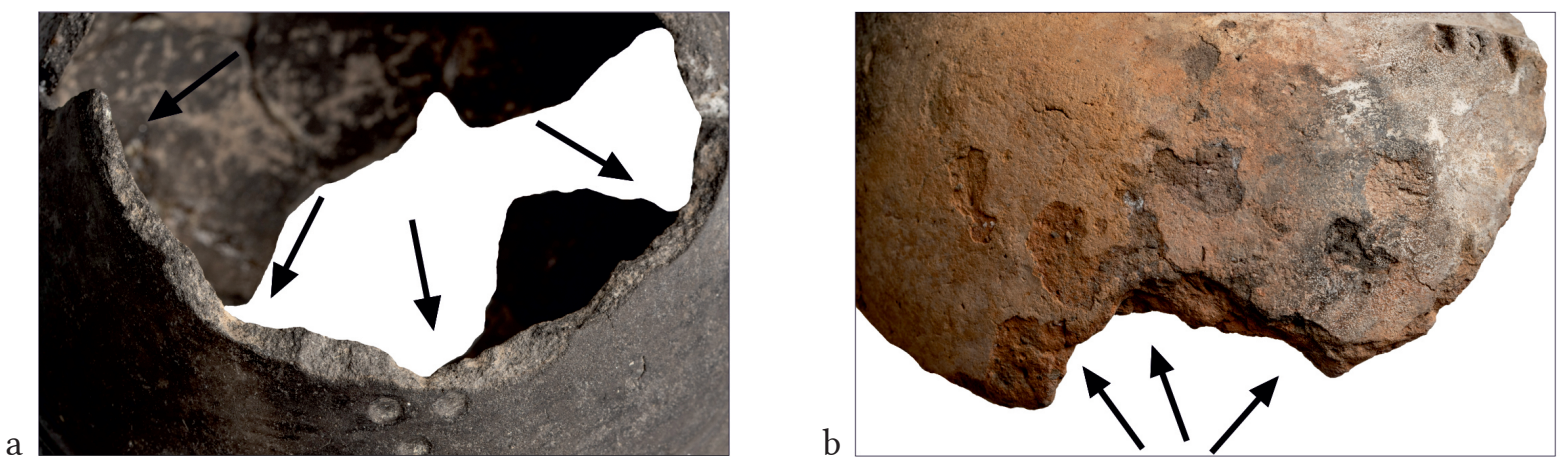

Fig. 8. Traces of blows on a - Vessel 7, and b-Vessel 16.

The applicability of potters' skills examinations decreases with the increase of ceramic fragmentation, therefore it is most effective on burial assemblages and object depots given the higher ratio of complete vessels. The relative 'value' of artefacts can also be assessed by the method. In our approach this relative value had three components: the first two are measurable characteristics while the last is a sentimental or symbolic factor. One of the measurable components is derived from the skill of the potter and is reflected by the vessel's stability (i.e. it is not wobbly when placed on a flat surface), and durability (i.e. ideal wall-thickness). The other measurable component lies in its usability or functionality (Fig. 10). The third component, however, is more difficult to evaluate. A broken or damaged object can be held in equally high esteem given its sentimental (e.g. gifted by an important person) or symbolic (e.g. involvement in a ritual) value beyond simple functionality.

The fact that this ceramic equipment was taken out of use was a result of a conscious decision. At the moment, there is no available information on the average number of ceramics utilised by a Bronze Age household, therefore the assemblage of Feature 80 can only be compared with

49 Kalicz-Schreiber 1995, 6, 8-9, 27-29; Zalotay 1957, 59, 61, 75-78.

50 Vessel 35 - Fig. 30.2, Vessel 36 - Fig. 31.1.

51 Vessel 53 - Fig. 28.6, Vessel 67 - Fig. 32.4. 


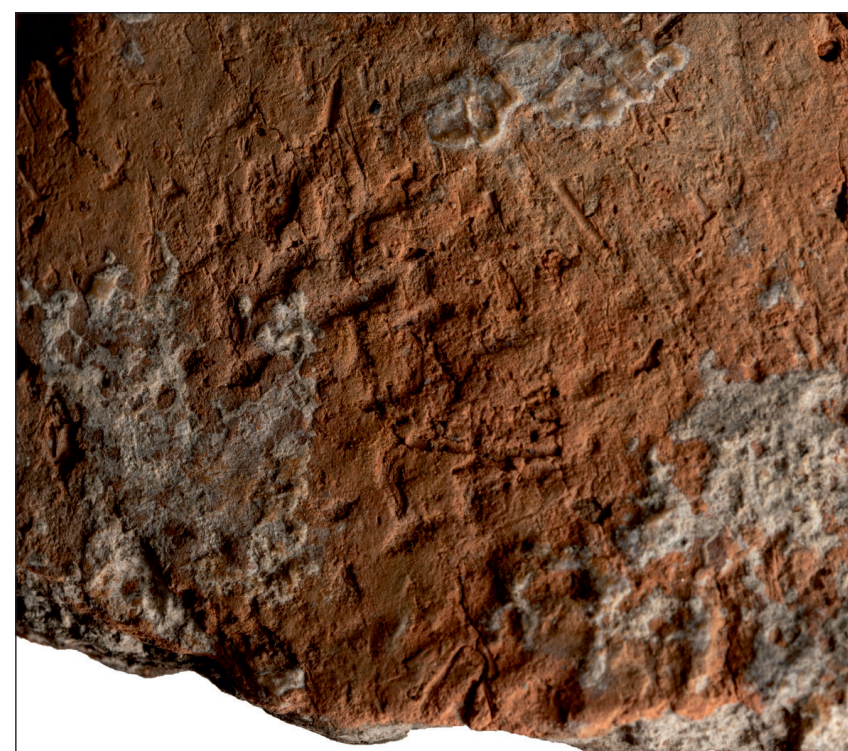

Fig. 9. Impression of a piece of textile on Vessel 49. contemporary urn burials. Storage vessels and cooking pots alone were included in this comparison as these ceramic types were also used as burial urns, and given their low ratio of fragmentation, it is almost certain that they were selected for the assemblage as complete vessels. Based on the storage vessels $s^{52}$ and cooking pots $^{53}$ included in the comparison, the pieces could have served as burial urns for altogether 15 individuals.

Since its special function, the fermentation vessel was not included in the comparison, although there are examples for burials in which such vessels were utilised as urns. ${ }^{54}$ An unusually large cooking pot was also excluded from the comparison. These two vessels were among the complete or almost complete ceramics of the assemblage (altogether 23 pieces). It is notable however, that the ceramic equipment of Feature 80 can not be compared to vessels in burial assemblages given the differences in the distribution of vessel types. ${ }^{55}$ Cups and bowls of Feature 80 were under-represented compared to the average numbers occurring at settlements and in cemeteries. The jugs, on the other hand, were over-represented in the assemblage; this ceramic type is quite rare to be included in burials, and as Magdolna Vicze suggested, they could be interpreted as prestige objects. ${ }^{56}$
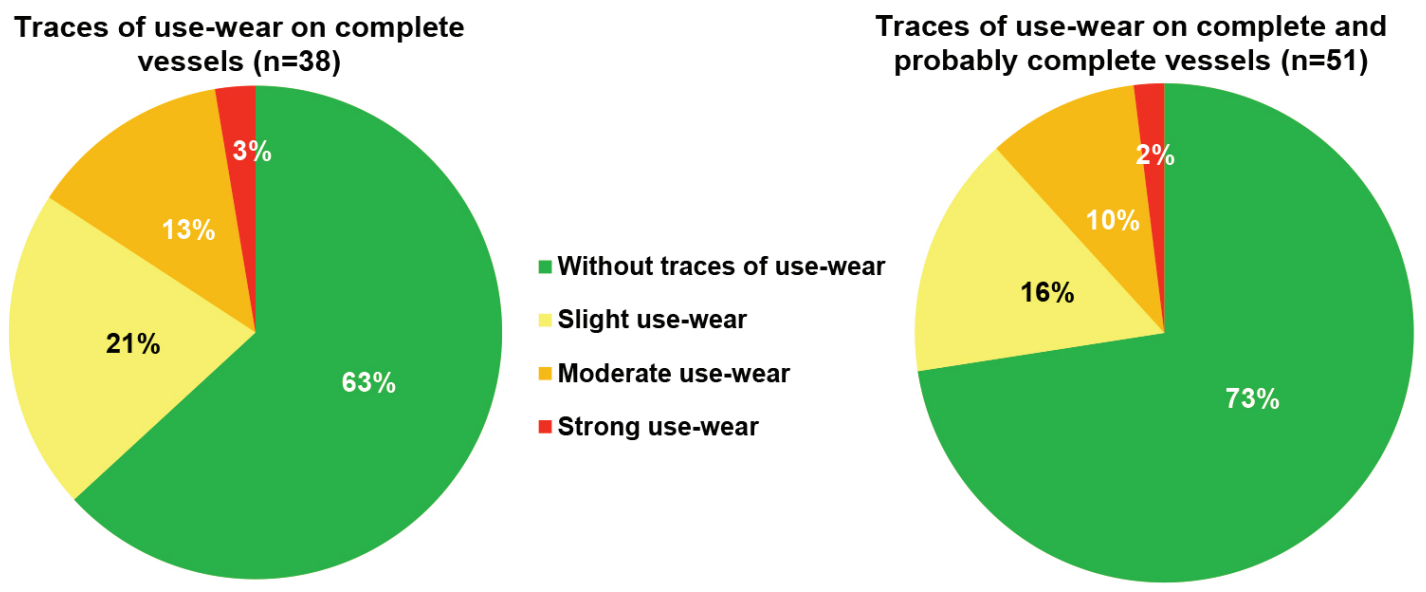

Fig. 10. Distribution of traces of use-wear on complete and probably complete vessels.

Vessel 42 - Fig. 18.1, Vessel 43 - Fig. 19.2, Vessel 44 - Fig. 26.4, Vessel 45 - Fig. 18.2, Vessel 46 - Fig. 20.3, Vessel 47 - Fig. 21.3, Vessel 48 - Fig. 22.3, Vessel 49 - Fig. 24.4, Vessel 50 - Fig. 23.2, Vessel 51 - Fig. 27.2, Vessel 54 - Fig. 23.1, Vessel 70 - Fig. 36.1.

53 Vessel 24 - Fig. 33.1, Vessel 25 - Fig. 34.1, Vessel 26 - Fig. 35.3.

54 Vicze 2011, Pl. 186. 2.

55 Generally, burials consisted of an urn, with a small bowl placed in the mouth (the right way up) then covered with a larger bowl (in upside-down position). Usually a small cup is included with the burial. KADA 1909, 128; BóNA 1975, 41-44; VicZe 1992, 92; KALICZ-Schreiber 1995, 36. 


\section{The phenomena of secondary burning and deliberate breakage of ce- ramics}

The phenomenon of secondary burning has long been known by ceramic specialists, but only a few years ago came to be explored in detail. ${ }^{57}$ The examination of secondarily burnt ceramics can shed more light on the life-cycles of objects, which could aid in reconstructing the usage and events impacting the vessel before and after the secondary burning took place. Based on the exposure to heat, ceramic fragments can be classified into three categories:

- superficially burnt pieces (Fig. 11.b, 11.c) where the brief exposure to heat, induced a slight (sometimes patchy) colour change on the fragments

- moderately burnt pieces (Fig. 12.a 12.b) show signs of oxidation

- severely exposed fragments (Fig. 13.a-d) are distorted, blistered or even vitrified - for this last category the ceramics were needed to be exposed to temperatures around $1100-1200{ }^{\circ} \mathrm{C}$ degrees. ${ }^{58}$
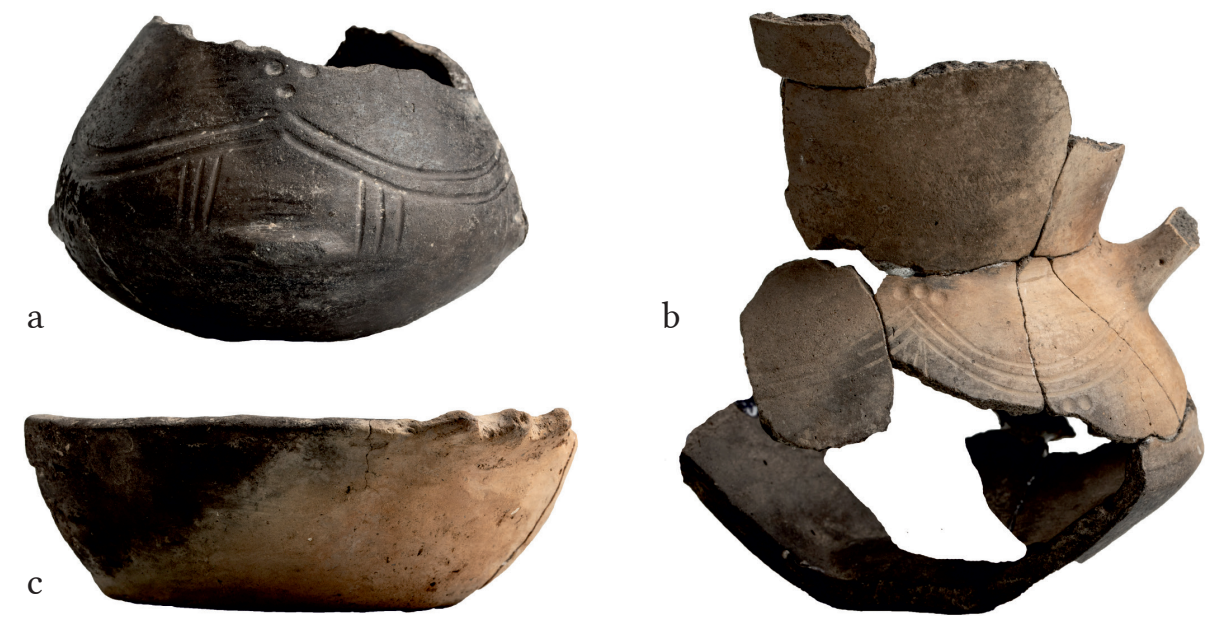

Fig. 11. a - Vessel 7 without traces of secondary burning, b-c - vessels with slight secondary burning (Vessel 5 and Vessel 19).

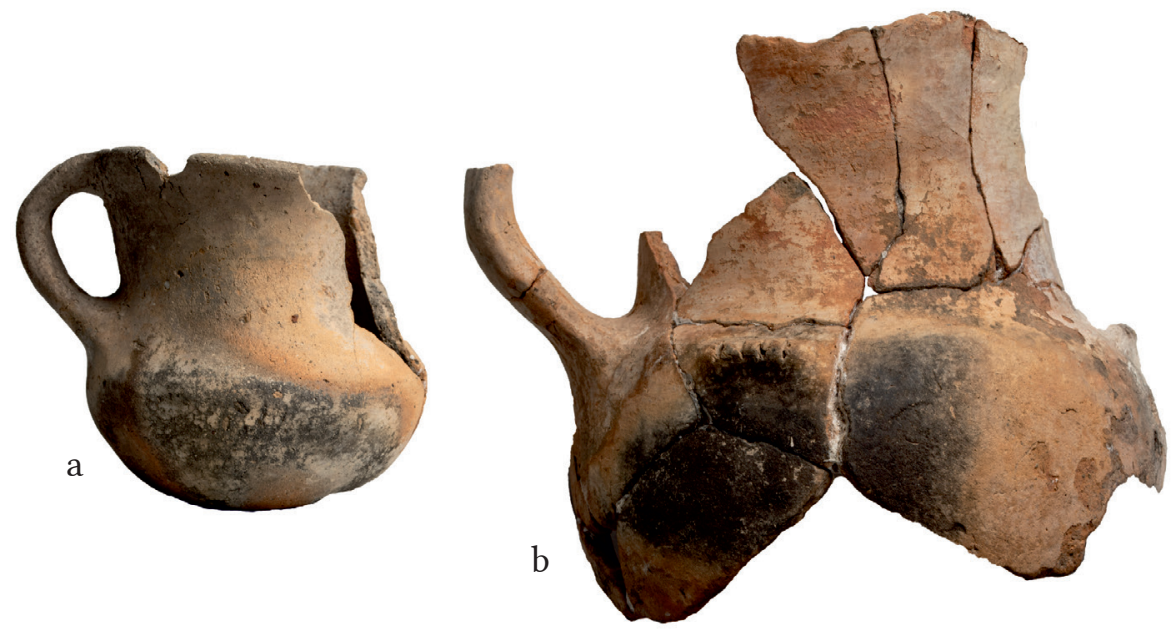

Fig. 12. Examples for vessels with traces of moderate secondary burning. a - Vessel 3, b - Vessel 16.

57 FÜLÖP - VÁCZI 2016, 3-4; GUCSI in print.

58 Gucsi in print. 


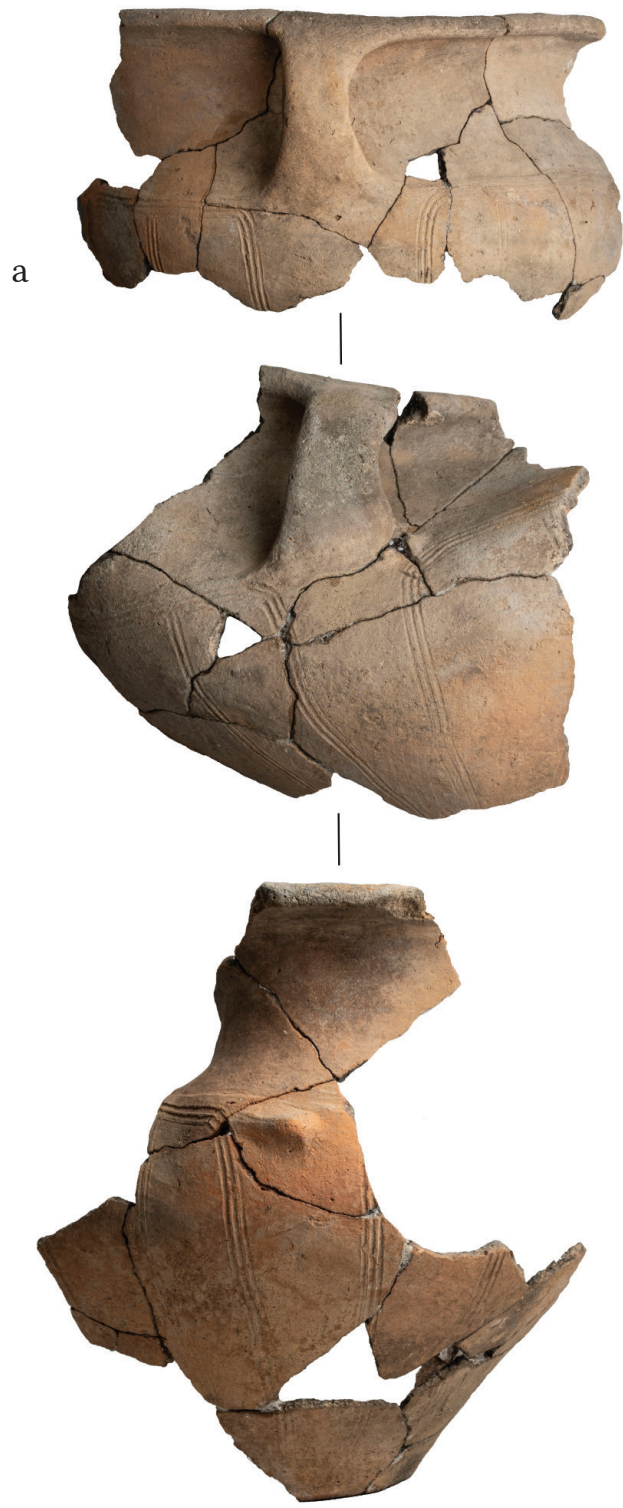

$\mathrm{b}$

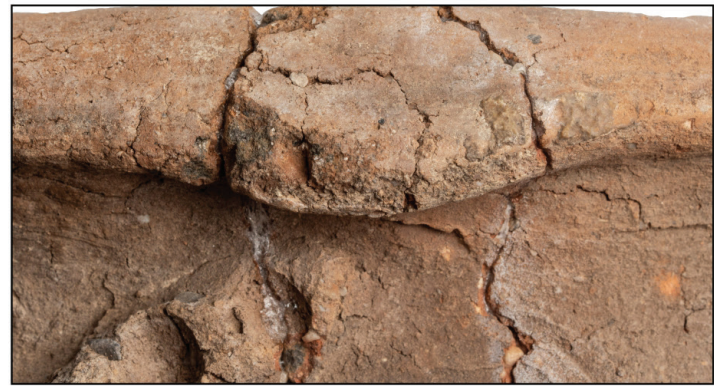

c

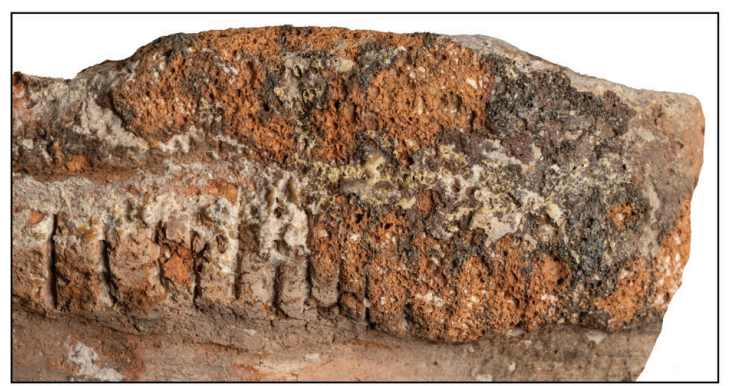

$\mathrm{d}$

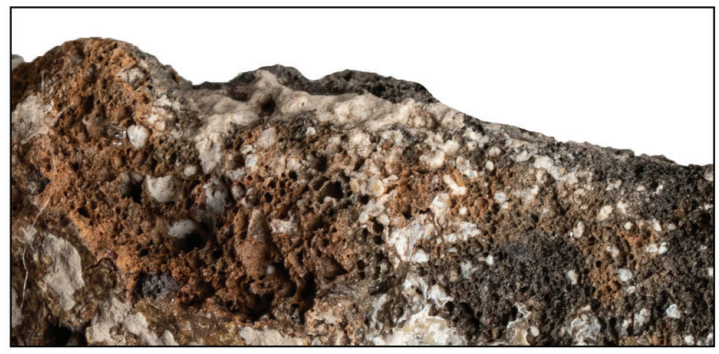

Fig. 13. Examples for vessels with severe secondary burning. a - heavily deformed (Vessel 36), b - distorted (Vessel 28), and c-d - vitrified (Vessel 30 and Vessel 70).

Examinations carried on the assemblage revealed that $79 \%$ of the entire assemblage recovered from Feature 80 was secondarily burnt (Fig. 14). ${ }^{59} 11 \%$ of ceramics which could be typologically identified showed signs of slight, $51 \%$ moderate and $39 \%$ severe secondary burning. There was only one instance where fragments of the same vessel exhibited diverse levels of oxidation suggesting that the sherds could have been scattered widely (thus were exposed to different levels of heat)(Vessel 35 - Fig. 30.2, 39.3). This observation also makes it highly likely that the majority of vessels were complete prior to secondary burning, or if they were not fully intact (such as Vessel 57 - Fig. 7.b, 25.2 and Vessel 58 - Fig. 26.1) a large segment of them were present during the burning event. Despite their fragmentary and incomplete condition, these latter, partial vessels could have been exposed to secondary heat in a more intact form. ${ }^{60}$

59 Taking all 238 body sherds and 72 diagnostic pieces into consideration, it could be concluded that $75 \%$ of the assemblage showed signs of secondary burning.

60 This assumption is based on the vessels' fragmentation structure, but whether the missing pieces were linked to processes of deposition or are missing due to more recent causes, it still unclear. 
The total lack of patchy oxidation on the assemblage implies that the vessels were neither placed high above the ground, nor were stacked in a pile; following the possible collapse of a supporting structure the vessels could have fallen, broken and their pieces scattered in different directions resulting in patchy exposure to heat. It is most likely that the vessels stood in one or maybe two rows on top of each other. This latter scenario is further supported by the fact that the majority of secondarily burnt pieces were also distorted implying exposure to pressure as well as heat.
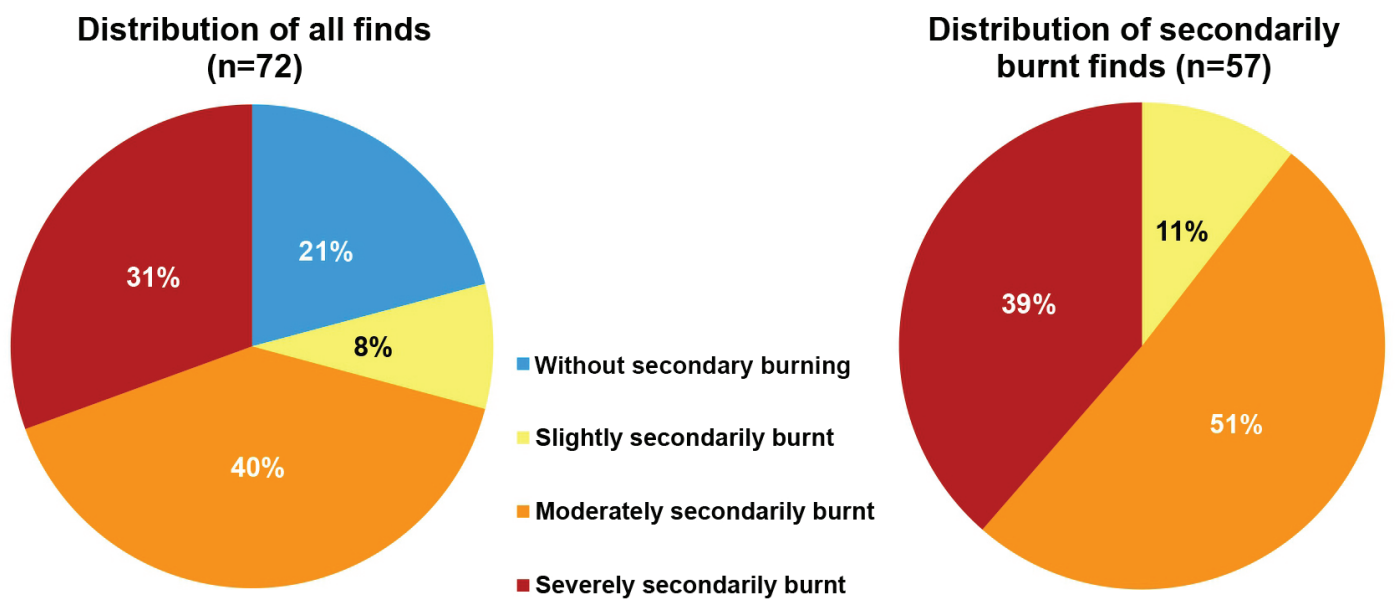

Fig. 14. Distribution of fragments showing signs of secondary burning.

Intriguingly, the majority of secondarily burnt vessels or fragmented pieces showed signs of breakage after the secondary burning event (Fig 39.1). Although some of these breakages could have occurred during the secondary burning event itself, but not in the initial phase, as the cross-section of ceramics did not oxidize. It is important to note here, that these breakages were not recent; they took place after the secondary burning episode but before they were excavated.

It is noteworthy that the fragmentation structure of the fermenting vessel is slightly different from the rest of the assemblage (Vessel 72 - Fig. 38.1). Despite its more robust, thicker walls the vessel broke into smaller, more rugged pieces than expected. Similar structures of fragmentation occurred on a small number of other vessels which could indicate that these objects were deliberately trodden on.

Seven vessels displayed traces of being hit or smashed (Fig. 8.b), these were all secondarily burnt pieces, representing $12 \%$ of the 52 secondarily burnt vessels. This suggests that vessels that have been cracked due to heat exposure were later deliberately broken into smaller pieces. ${ }^{61}$

Based on the breakages on its rim, the storage vessel of (Vessel 46 - Fig. 20.3) suffered two vertical blows by a sharp implement while standing in an upright position. In the case of another storage vessel (Vessel 47 - Fig. 21.3) multiple blows could be detected, one of them - indicated by a puncture mark on the interior - impacted the vessel horizontally from the inside. ${ }^{62}$

61 Unfortunately, due to the lack of archaeological documentation, the exact position of the vessels in the pit is unknown, however according to record shots and context descriptions, at least two relatively complete storage vessels stood in an upright position leaning against the walls of the pit, while the majority of vessels were already broken when placed into the centre of the feature.

62 Given the earlier blow, it is possible that the vessel fell on its side (in a roughly 45 degree angle) when it was punctured from the inside with a sharp implement. A larger rim fragment of this vessel has different colour than the rest of the pot. This suggests that the breakage of these two storage vessels happened when the fire was burning on a high enough temperature to be able to oxidize a number of fragments nearby. 
Taking secondarily burnt ceramics into consideration by vessel type, a couple of interesting details emerge (Fig. 15). The majority of cooking pots showed signs of severe secondary burning (in seven cases out of nine $=78 \%$ ). This is three times higher than the ratio detected among the three other vessel types: $24 \%$ of storage vessels (7 pieces), $33 \%$ of deep bowls (3 pieces), and $25 \%$ of jugs (3 pieces) were severely secondarily burnt. Therefore, while a quarter or a third of storage vessels, bowls and jugs were severely burnt, three-quarters of the cooking pots could be reconstructed to have stood near the hottest sector of the fire. The fermenting vessels can also be included here, since they statistically represent two ceramic units within this category: one of them was represented by a single sherd, while the other was an almost complete vessel, $40 \%$ of which was discovered in Feature 80.

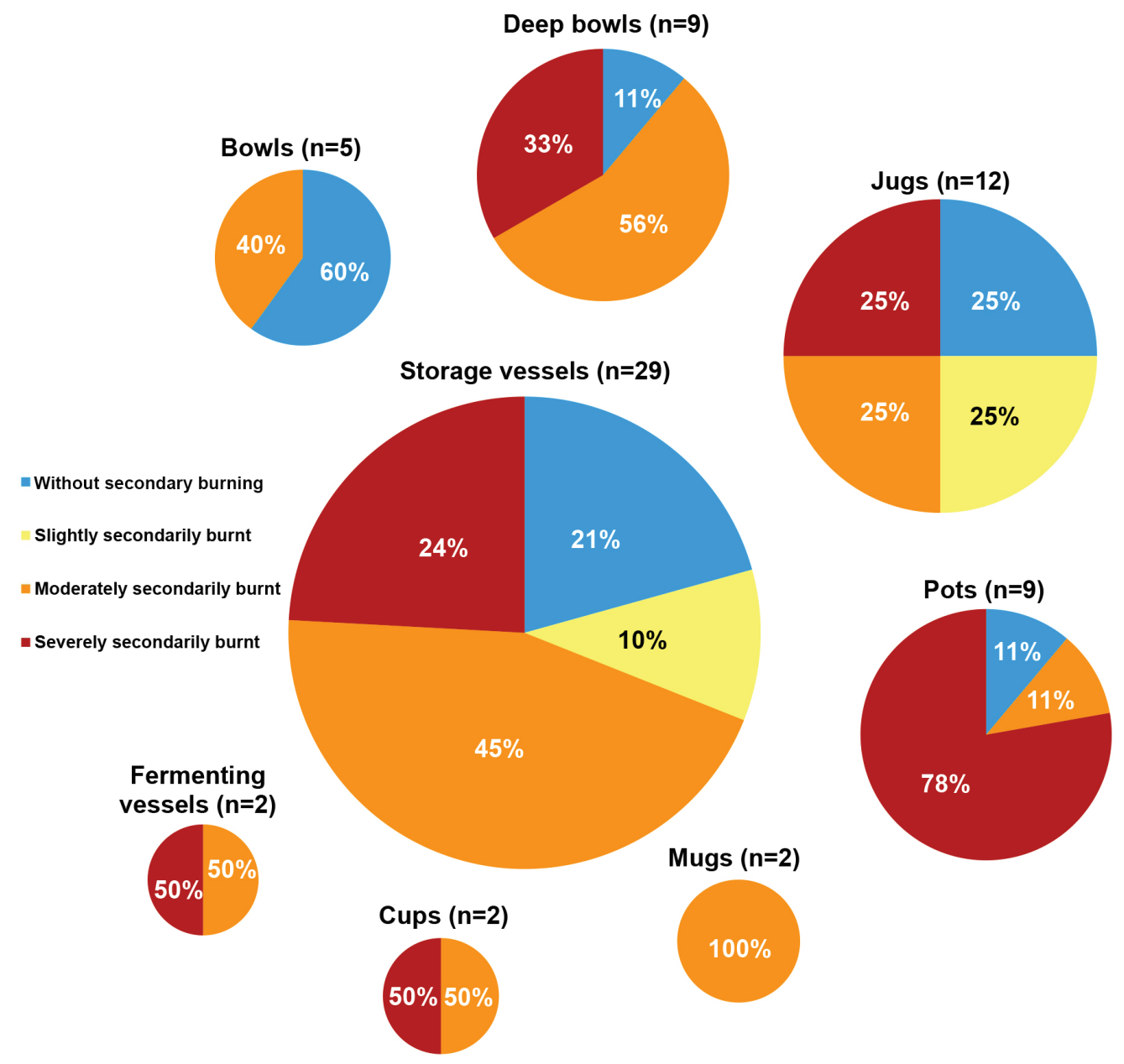

Fig. 15. Distribution of ceramics with secondary burning by vessel type.

The distribution of secondarily burnt artefacts suggests that the fermenting vessel (Vessel 72 - Fig. 38.1), a large storage vessel (Vessel 70 - Fig. 36.1) and the large-sized cooking pot (Vessel 27 - Fig. 37.1), moreover the rest of the cooking pots could have been closest to the hottest part of the fire, which also indicates that these vessels could also have been in the focal point of the (deliberate) burning event. Moderate secondary burning occurred dominantly among storage vessels and deep bowls. Vessels with slight secondary burning were storage vessels (10\%) and jugs (25\%). Ceramics on which traces of secondary burning were not detected - apart from vessel types of minimal statistical quantity (such as cups, mugs, fermenting vessels) - represented all typological categories. The examination of distribution 
implies that the burning of large quantities of ceramics were part of a deliberate and consciously planned act. However, as the rest of the (unburnt) assemblage suggests, this event (or a related activity) had a component which did not involve the burning of ceramics.

The curved right side of an Early Bronze Age fragment (Vessel 22 - Fig. 38.2) from the rim all the way to the horizontal break surface was badly worn with traces of moderate secondary burning. The vertical left break surface occurred after the secondary burning event. This implies that a relatively large vessel fragment, which by then was a couple of hundred years old, had a secondary use-life in the Vatya-Koszider period..$^{63}$ Therefore, it is probable that the presence of this Early Bronze Age sherd in the assemblage is not accidental, but could have played an important role (such as representing a tangible link with the ancestors) during the series actions that brought about the structured deposition. ${ }^{64}$ We would suggest that the inclusion of vessels in the assemblage which did not show signs of secondary burning was most possibly deliberate, however, it needs to be pointed out here that occasional unburnt fragments could have made it into the contents during the backfilling process.

\section{A possible reconstruction of the pyre}

In order to examine ceramic fragments with traces of severe secondary burning, both the size and location of vessels need to be taken into account. Our assessment is based on the smallest possible floor area along with the minimal amount of fuel necessary for secondary burning to have taken place. Therefore considering the (almost) complete vessels' widest circumferences two possible scenarios can be outlined (given the pots were standing close together on the smallest possible floor space) (Fig. 16).

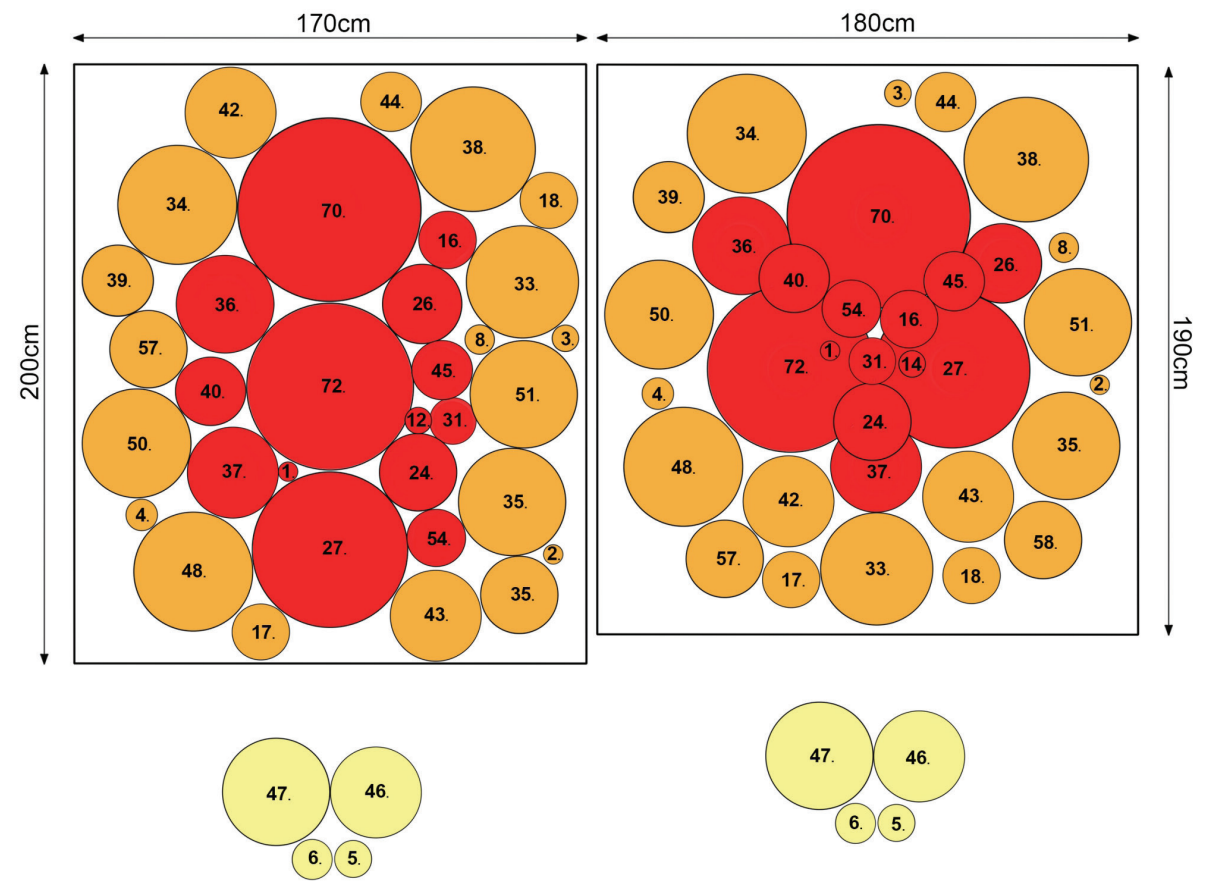

Fig. 16. Possible reconstructions of a pyre with vessels covering the smallest possible floor area.

63 Chapman - Gaydarska 2007, 75-76.

64 Kreiter 2007a, 160-162; Kreiter 2007b, 130. The pit contained a further Early Bronze Age fragment that showed no trace of secondary burning (Vessel 23 - Fig. 38.3). 
In both reconstructions the vessels that suffered severe secondary burning stood in the centre surrounded by pieces with moderate secondary burning. The first scenario imagined the larger vessels lined up and the rest of the ceramics grouped around them as close as possible. The minimum floor space required for this was an area of $170 \times 200 \mathrm{cms}$. The second scenario assumed that the three largest vessels were placed on the ground forming a triangle, and the pots with severe secondary burning stood next to and/or on top of them. The stack was then surrounded by vessels showing signs of moderate secondary burning. In this case, the required floor space was an area of $180 \times 190 \mathrm{cms}$. For both scenarios a minimum of $3.4 \mathrm{~m}^{2}$ was the smallest area necessary, given the number and the widest circumference of the vessels.

The amount of firewood required for the secondary burning event was also considered. Since patchy secondary burning is almost completely lacking on the pieces, the pyre could not have been very high. If an approximately $50 \mathrm{~cm}$ tall pyre erected of slats of wood built in a grid structure (the net volume of firewood, without gaps, could be estimated to around $25 \mathrm{cms}$ in height) in an area of $3.4 \mathrm{~m}^{2}$ the construction would have required firewood of $0.85 \mathrm{~m}^{3}$.

Since there was no evidence for either a burnt-down building or remains of a pyre, the location and spread of the fire, or the burning process cannot be reconstructed at this point. Nevertheless, the effects of heat detected on the vessels imply

- that they could have been packed tightly together in a small space or room, ${ }^{65}$ and

- even a small pyre could have been sufficient to inflict the level of secondary burning documented on the ceramics. ${ }^{66}$

\section{Vessel capacity and the reconstruction of a possible feasting event}

Ceramic depositions - particularly if they contain large amounts of drinking vessels - can be regarded as the remains of ritual feasts. ${ }^{67}$ The most recent studies show that feasting events had an outstandingly important role in the lives of prehistoric societies. ${ }^{68}$ The number of people being present at such events can shed some light on whether the feast was a ritual event or it was carried out within a social - family/wider family or a regional/interregional - framework. In order to estimate the number of participants, the capacity of the vessels had to be calculated. ${ }^{69}$ In case of the fermenting vessel, the calculation only considered the volume below the holes puncturing the shoulders (which acted as overflows during the fermentation). The (functional) capacity of storage vessels was measured up to the point where the neck joined the shoulder. For deep bowls and cooking pots the interior curve of the neck/rim represented the limit of volume held by the vessels.

Taking the capacity of the more complete or restorable vessels into account, there is a strong correlation between the volumes of vessels that belonged to the same typological category. ${ }^{70}$

65 For examples on the dimensions of buildings, see Poroszlai 2000b, 118-122; Vicze 2013a, 183.

66 GHERDÁN et al. 93; FÜLÖP 2018.

67 Kalla et al. 2013, 26-27.

68 Recently several case studies and summaries have been published in this topic: Dietler - HaYden 2001; Dietrich - Heun 2012; Kalla et al. 2013; Hayden 2014; Pollock 2015.

69 Similar measurements were carried out by Ildikó Szathmári (SzATHMÁRI 2009, 298-300).

70 In order to measure the capacity of the vessels, pots were divided into smaller units for which the appropriate formulas were used to calculate the volume, before the sums were added together. 
The total capacity of the four cooking pots ${ }^{71}$ was 120 litres, while the deep bowls ${ }^{72}$ measured 111.2 litres, and the storage vessels ${ }^{73} 110.7$ litres. It has to be mentioned here that the largest of storage vessels was not considered within its own typological category, but - given its distinct size, shape and position during the burning event - was examined and interpreted together with the fermenting vessel and the large cooking pot. ${ }^{74}$ The functional capacity of the fermenting vessel was 60 litres, the same as the volume of the above mentioned largest storage vessel, thus their joint capacity could have been around 120 litres. It is perhaps not a coincidence that the overall volume of vessels distributing among the four other typological categories (storage, cooking, consumption and unusual sized) was also around 110-120 litres. Thus the overlaps between vessel capacities could imply a link between the preparation and consumption of foodstuffs at this particular event. To be more precise, in this case it appears that the fermenting vessel along with the large storage vessel was used to brew some kind of alcoholic berverage which then was served in smaller storage pots. ${ }^{75}$ Furthermore food was prepared in cooking pots and served in deep bowls. If the average-sized stomach capacity ( $800 \mathrm{ml} /$ person, considered by medical research) is taken into account, ${ }^{76}$ the feast could have involved 110-120 litres of foodstuffs providing for about 130-150 persons.

\section{The possible interpretations of the assemblage}

Before discussing the possible interpretations of the assemblage, attention needs to be drawn to two key aspects. Firstly, the deposition of the assemblage in the pit was the outcome of a conscious and deliberate series of actions, therefore it cannot be treated as regular household waste. ${ }^{77}$ Secondly, the vessels were deliberately broken and damaged before being deposited in the pit altogether at the same time. ${ }^{78}$ In order to offer an interpretation for the assemblage, both quantitative and qualitative factors need to be taken into consideration. The quantitative data could shed light on the reasons behind the deposition, while the qualitative information could illuminate the process of deposition.

The practice of ceramic deposition was documented in all periods throughout the Bronze Age ${ }^{79}$ their composition, physical deposition and reasons behind the depositions are varied depending on the time period and the cultural context. ${ }^{80}$ The largest number of depositions

71 Vessel 24 - Fig. 33.1, Vessel 25 - Fig. 34.1, Vessel 26 - Fig. 35.3, Vessel 27 - Fig. 37.1.

72 Vessel 33 - Fig. 29.2, Vessel 34 - Fig. 29.1, Vessel 35 - Fig. 30.2, Vessel 36 - Fig. 31.1, Vessel 37 - Fig. 31.2 , Vessel 38 - Fig. 36.2, Vessel 39 - Fig. 30.1, Vessel 40 - Fig. 32.1.

73 Vessel 42 - Fig. 18.1, Vessel 43 - Fig. 19.2, Vessel 44 - Fig. 26.4, Vessel 45 - Fig. 18.2, Vessel 46 - Fig. 20.3, Vessel 47 - Fig. 21.3, Vessel 48 - Fig. 22.3, Vessel 49 - Fig. 24.4, Vessel 50 - Fig. 23.2.

74 Ildikó Szathmári (SzATHMÁRI 2009) in the same publication considered the topic of large cooking pots which she suggests were used for storing solid foodstuffs as it was problematic to cover and/or to move them around. However, we would argue that their coverage could have not posed a serious issue since this could be done by using large bowls as lids among many other options. We would also propose that large cooking pots were suitable for food preparation as they fit the grated hearths with diameters of $40-50 \mathrm{cms}$ such as the ones discovered at Százhalombatta (Vicze 2013b, 762, Figs 4-5).

75 Traditionally, the research connects the fermenting vessel to alcohol or fermented dairy products (HoRVÁTH 1974, 57-61; KulCSÁR 1997, 34), however there is no scientific evidence which proves this theory.

76 Geliebter - Hashim 2001, 745-746, Geliebter et al. 2004, 737, Fig. 1.

77 As implied by complete vessels deposited upside-down.

78 Apart from the typo-chronological assessment of the vessels, pots found in pairs and with traces of secondary burning suggest a similar scenario as well.

79 For example: Kovács 1978, 221; Tóth 1999, 33-35; V. Szabó 2004; Ilon 2012, 19-30; Ilon 2014, 9, Abb. 3.

80 Stapel 1999; Palátová - Salaš 2002, 145-153. 
were documented from within settlements, placed nearby domestic buildings. In most cases the ceramics were found complete and packed on top of each other, consisting of vessel types linked to the consumption of food and drink. ${ }^{81}$

The ceramic assemblage discovered at Budajenő so far stands without example in the Carpathian Basin. The characteristic Vatya ceramic depots consisted of cups exclusively; ${ }^{82}$ a tradition that can be traced back to the Early Bronze Age. ${ }^{83}$ In this case, however, the characteristics of the assemblage were different: considering the distribution of vessels of distinct functions and their typochronology, the deposition shows attributes similar to Late Bronze Age traditions. As opposed to the Vatya cup depots, Late Bronze Age assemblages sometimes consisted of medium and large storage vessels, numerous small drinking vessels, and a few large serving vessels. ${ }^{84}$ Nevertheless, the material of Feature 80 cannot clearly be associated with either, since almost all typological categories of the Vatya ceramic repertoire were represented here, while the small number of cups, jugs and bowls, and the large number of storage vessels also stand without analogues in the Middle Bronze Age. In terms of their contents, a similar assemblage is known from the vicinity of Veszprém, where around 70 vessels and additional fragments were documented from a pit dated to the Br B1. This assemblage also included numerous storage vessels, along with drinking and serving vessels coming to light in similar numbers. ${ }^{85}$

For the interpretation of the assemblage both profane and ritual explanations can be considered. In the case of features containing numerous storage vessels, it is difficult to distinguish between the two explanations, since the assemblage could have been the outcome of a commonplace event such as a house going up in flames. ${ }^{86}$ However, in the case of ritual depositions, the emphasis is on the vessels' participation in a certain chain of events rather than on the vessel itself. The quality and value of the vessel - which in this way was removed from its regular, domestic context - is 'wasted', thus elevates the importance of the ritual performance. ${ }^{87}$

Given the variety of vessel types and their large quantity, the Budajenő assemblage could be interpreted as the ceramic equipment of a domestic household. Although similar assemblages in Vatya contexts are still lacking, a comparable formal example is known from the site of Túrkeve-Terehalom, from the Koszider phase of the Gyulavarsánd culture, where a complete dinner set was discovered. Although the two assemblages are similar in their composition, they cannot be genuinely compared as the contexts of their depositions were different. ${ }^{88}$ In terms of the representation of vessel types, the contents of Feature 80 could be best compared to an example dating to the Szigetszentmiklós and Kulcs phase of the Early Bronze Age Nagyrév complex. At the settlement of Dunaújváros-Rácdomb an in situ ceramic assemblage came to light from among the remains of a burnt-down domestic building. Here, storage vessels and cooking pots characterised the bulk of the assemblage, while bowls, cups and jugs were represented only in small numbers. ${ }^{89}$

Kalla et al. 2013, 24-25.

KovÁcs 1978, 221.

P. Fischl et al. 1999, 77, 99.

V. SzABó 2004, 86.

ILON 2012, 19-30, 38.

V. SzABó 2004, 87.

StAPEl 1999, 139-141; V. SzABó 2004, 87; KAlla et al. 2013, 28.

CsÁnyi - TÁrnoki 1992, 162, Abb. 118; CsÁNyi - TÁrnoki 2013a, 708; CsÁNyi - TÁRnoki 2013b, 14.

NYíri 2013, 165, 2. kép, 171, 5. kép. 
Taking the second aspect, namely the qualitative characteristics of vessels, into account, pieces which display traces of secondary burning need to be examined.

It is still not clear whether the operation of full-time ceramics specialists can be considered during the Middle Bronze Age, however, a few cases indicate that there could have been individuals at this time who produced ceramics in large series. ${ }^{90}$ Since there were not one, but two pairs of vessels known from Feature 80 (with further possible cases) which appear to be the works of the same craftsperson, it would be feasible to assume that the contents of the pit were a failed batch of fired ceramics. In the Middle Bronze Age, ceramics were fired at temperatures around $650-850{ }^{\circ} \mathrm{C},{ }^{91}$ but these temperatures were not high enough to produce such changes in the clay structure as it is seen on some pieces of the Budajenő assemblage. Blistered, vitrified surfaces and amorphous shapes occur at significantly higher temperatures, at approximately $1100-1200{ }^{\circ} \mathrm{C}$, during which the so-called ceramic-slag is produced..$^{92}$ Since the majority of the vessels was the works of a level 4 or 5 craftsperson(s), it is difficult to imagine that a skilled potter would have made such a fatal error. ${ }^{93}$ If temperatures of $1200{ }^{\circ} \mathrm{C}$ were reached by applying Bronze Age pyrotechnologies,${ }^{94}$ then vessels fired in the same batch would have not shown such variability (as it is displayed by the Budajenő pieces). The detailed examination of individual vessels detected use-wear on the ceramics, which further implies that the assemblage was not a result of failed firing.

The above outlined scenario of a burnt-down building in the case of Middle Bronze Age tell settlements is generally associated with both profane and ritual events, that appears to be deliberately planned..$^{95}$ Ceramic and daub fragments with blistered, vitrified surfaces, sometimes even transformed into slag suggest that the temperatures reached above $1100{ }^{\circ} \mathrm{C} \mathrm{im}$ plying deliberate human action. ${ }^{96}$ In this case the assemblage is assumed to have been used and stored in the building destroyed by the fire. Given the composition of the assemblage and the different degrees of secondary burning detected on the vessels (of which some testify of temperatures higher than $1100{ }^{\circ} \mathrm{C}$ ) it is feasible to assume that Feature 80 contained the household equipment of a destroyed domestic building. During the burning event, temperatures are presumed to vary in different sectors of the building, which could explain the different levels of secondary burning exhibited by the vessels. ${ }^{97}$ If the building burnt down due to profane, commonplace reasons then the vessels would have been discovered randomly within the house or in patterns indicating the presence of furniture. However, in this case, the burning of the building appears to be a deliberate event, where the vessels were taken out of their usual domestic contexts, then placed in the pit implying ritual action. The intentional breakage and damage inflicted on the vessels further supports the ritual nature of the events. ${ }^{98}$ Nevertheless, there is so far no evidence for a charred building structure neither around the pit nor from its close surroundings.

90 Michelaki 2008, Fig. 13; Budden - Sofaer 2009, Fig. 4; Antoni et al. 2010, 148; P. Fischl et al. 2013, $262-263$.

91 Michelaki 2006, 11; Kreiter et al. 2007, 44.

92 Stevanović 1997, 366; DAszkiewicz - Schneider 2001, 28; Hoeck et al. 2012, 662; GHeOrghiu 2007, 38-39; Gheorghiu 2008, 63; Gherdán et al. 2010, 92-93; GHeorghiu 2016, 46.

93 SOFAER 2015, 125.

94 Michelaki 2006, 11; Kreiter 2010; Gucsi in print.

95 BANKoff - Winter 1979, 13; Chapman 1999, 122-123; GogÂltan 2012; SzEverÉNYi 2013, 217-218.

96 Stevanović 1997, 373; Tringham 2005, 105-106; Akkermans et al. 2012, 312; Gheorghiu 2016, 45-46.

97 NYÍRI 2013, 172; CsÁNyi - TÁRNOKI 2013a, 714.

98 Chapman 2000; Chapman - Gaydarska 2007; Spatzier 2017, 384. 


\section{Summary and the description of a possible chain of events}

Although the exact reasons for the deposition of ceramics remain nebulous, it is possible however, to outline a chain of events based on the examination of vessels, which can be described as a ritual or symbolic performance. In this way the intentions behind and timeframe of the deposition cannot, but the size of the feast, the selection of objects, the place and process of secondary burning and the final deposition of vessels can be reconstructed.

In our opinion the most likely scenario is that the event represented a significant episode in the life of a community, suggested by the quantity and conscious selection of vessels (works of master potters, relatively few traces of use-wear and damage, the selection of 'twin' vessels) and by subsequent treatment of the pieces (signs of secondary burning, deliberate breakage). ${ }^{99}$ However, whether this significant event was related to a single person, or a wider community, given the evidence so far it is impossible to say. Nevertheless, the symbolism of 'twin' vessels occurring in pairs indicates that two persons could have been in the centre of events.

It is possible that a community meal or feast common among prehistoric societies formed part of the event, during which the meal (following a prescribed ritual narrative) was prepared, served and consumed from the vessels that ended up in the deposition. ${ }^{100}$ If the event included the participation of the wider community, then the guests must have come prepared with their own dining sets, which were later excluded from the burning of sacrificial equipment that took place either indoors or outdoors.

Following the feast - as suggested by traces of secondary burning - the vessels were exposed to direct heat. This could have been carried out in two ways:

- the vessels were either placed inside a building which was then set alight,

- or taken outdoors and burnt on a pyre. In both instances the vessels were still complete, and installed next to, or stacked on top of each other in two rows.

In the hottest sector of the fire stood the fermenting vessel, the large cooking pot, the largest storage vessel, six regular-sized cooking pots, six regular-sized storage vessels, three deep bowls and three jugs. These were surrounded by further vessels, which later showed signs of moderate secondary burning. In the gaps in between the vessels fragmented ceramics were placed which were broken prior or during the event. It seems that for the selection of fragmented pieces, it was important that the ceramics preserved some of their diagnostic, easily recognisable features. A fragment dating to the Early Bronze Age was also included in the assemblage. ${ }^{101}$

If the burning event was carried out outdoors - depending on the amount of firewood available - the fire could have burnt for about three to six hours. ${ }^{102}$ A group of four vessels - two of the 'twin' pots (Vessel 5 - Fig. 20.1, Vessel 6 - Fig. 20.2) and two storage vessels (Vessel 46 - Fig. 20.3, Vessel 47 - Fig. 21.3) were among the complete but slightly secondarily burnt ceramics (Fig. 16) which could have been placed on the fire towards the last stages of the event

99 Gheorghiu 2016, 44.

100 Kalla et al. 2013, 36-38.

101 The phenomenon was discussed by scholars before (CHAPMAN 1999, 121; CHAPMAN 2000, 105-106; CHAPMAN - GAYDARSKA 2007, 3-4).

102 FÜLÖP 2019. 
but when the embers were still hot. ${ }^{103}$ Right after the fire died down, the vessels which stood near the doorway could have been smashed.

There are two possibilities for the chain of events that could have taken place after all the firewood was consumed. If the vessels were burnt with the house, the pieces could have either been collected the day after when the wreckage cooled down (the destruction of still standing structural parts of the building could have also occurred at this time) or water was thrown onto the smouldering remains and on the floor. If the vessels were burnt on a pyre, the collection of pieces could have also been done next day, but if the pyre was treated with water, the ceramic pieces could have been buried straight away.

Following the burning event, the still complete vessels were broken by a series of blows, some of them were even trampled upon. Some of the fragments ${ }^{104}$ were then collected and taken to the pit. Since the pit in which the assemblage was placed is similar in its dimensions to other regular refuse pits occurring all over the settlement, it is difficult to ascertain whether it was dug purposefully for this particular event or a previously dug and emptied refuse pit was used. Before burying the vessels and backfilling the pit, pieces of used but diagnostic fragments were collected from the settlement, moreover, an Early Bronze Age fragment was also added to the deposit. It could be suggested that ceramic fragments associated with different time periods could be understood as the representations of the community's cultural memory during the event. Therefore the presence of Early Bronze Age ceramic pieces, along with fragments exhibiting use-wear, and vessels showing signs of severe, moderate and slight secondary burning in the pit is not a coincidence.

However, unfortunately, the exact chain of events cannot be reconstructed here since both the wider context of the feature remains unknown and similar examples are still lacking. Nevertheless the examination of the assemblage indicates that the selection of vessels, their treatment, and simultaneous installation in the pit was the result of a deliberate action. Thus the assemblage can be described as a structured deposition. ${ }^{105}$ The aim of this paper was to demonstrate that detailed and multi-perspective examinations can bring us closer to deciphering the reasons behind structured depositions.

\section{Acknowledgements}

Here we would like to express our gratitude to the site director, Tamás Repiszky from the Ferenczy Múzeumi Centrum for allowing us to publish the assemblage. We are also very thankful for the great support of Gábor Sima (Ferenczy Múzeumi Centrum). We are indebted to Nóra Szilágyi, who took the very detailed photographs of the vessels of Feature 80. Furthermore we are also grateful to Borbála Nyíri, who did not only offer her help with the translation, but also gave us valuable advices on the article.

103 Doorways and thresholds could have had an important role in the ritual transition, as indicated by ethnographic examples (OrTutAy 1977, 53).

104 The data indicates that only $40 \%$ of the vessels involved in the ritual event were part of the deposition, although in reality this ratio could have been slightly different. According to our estimates, around $29 \%$ of vessels came to light during the documented excavation. Given the depth of the pit $(60 \mathrm{cms})$ and the humus layer above (approx. $20 \mathrm{cms}$ ) moreover, the upper layers of the pit that could have eroded away, it can be assumed that $40 \%$ of the original deposition came to light during the excavation.

105 Richards - ThOMAs 1984, 204-206. 


\section{References}

Antoni, J. - Csupor, I. - Udvardi, B. 2010: Régi fazekasok öreg cserepei (Adalékok a korabronzkori fazekassághoz) (Old sherds of ancient potters [Contributions to Early Bronze Age pottery]). In: Kvassay, J. (ed.): Évkönyv és jelentés a Kulturális Örökségvédelmi Szakszolgálat 2009. évi feltárásairól (Field service for cultural heritage 2009 yearbook and review of archaeological investigations). Budapest, 137-161.

Akrermans, P. M. M. G. - Brüning, M. - Hammers, N. - Huigens, H. - Kruijer, L. - Meens, A. Nieuwenhuyse, O. - RaAt, A. - Rogmans, F.E. - Slappendel, C. - Taipale, S. - Tews, S. VISSER, E. 2012: Burning down the house: the burnt building V6 at Late Neolithic Tell Sabi Abyad, Syria. In: Bakels, C. - Kamermans, H. (eds.): The end of our fifth decade. Analecta Prehistorica Leidensia 43/4. Leiden, 307-324.

Bankoff, H. A. - Winter, F. A. 1979: A House-burning in Serbia. Archaeology, 8-14.

Bondár, M. - Raczky, P. (eds.) 2009: The Copper Age cemetery of Budakalász. Budapest.

BóNA, I. 1975: Die mittlere Bronzezeit Ungarns und ihre südöstliche Beziehungen. Archaeologica Hungarica 49. Budapest.

BónA, I. - NovÁki, Gy. 1982: Alpár bronzkori és Árpád-kori vára. (Alpár, eine bronzezeitliche und mittelalterliche Burg). Cumania - A Bács-Kiskun Megyei Múzeumok Közleményei 7, 17-164.

Budden, S. - Sofaer, J. 2009: Non-discursive knowledge and the construction of identity. Potters, potting and performance at the Bronze Age tell of Százhalombatta, Hungary. Cambridge Archaeological fournal 19/2, 203-220.

Budden, J. - Sofaer, S. 2012: Many hands make light work: potting and embodied knowledge at the Bronze Age tell at Százhalombatta, Hungary. In: Stig Sørensen, M. L. - Rebay-Salisbury, K. (eds.): Embodied Knowledge. Perspectives on Belief and Technology. Oxford, 117-127.

Chapman, J. 1999: Deliberate house-burning in the prehistory of central and eastern Europe. In: GusTAFFSON, A. - KARLSSON, H. (eds.): Glyfer och arkeologiska rum: En vänbok till farl Nordbladh. Gotarc series A/3. Göteborg, 113-126.

Chapman, J. 2000: Fragmentation in Archaeology. People, place and broken objects in the prehistory of south-eastern Europe. London-New York.

Chapman, J. - Gaydarska, B. 2007: Parts and Wholes: Fragmentation in prehistoric context. Oxford.

CsÁnyi, M. - TÁrnoki, J. 1992: Túrkeve-Terehalom. In: MeIER-Arendt, W. (ed.): Bronzezeit in Ungarn. Forschungen in Tell-Siedlungen an Donau und Theiss. Frankfurt am Main, Budapest, 159-165.

CsÁnyi, M. - TÁrnoki, J. 2013a: A Dinner Set from a Bronze Age House in Level 2 of the Túrkeve-Terehalom Settlement. In: Anders, A. - Kulcsár, G. - Kalla, G - Kiss, V. - V. Szabó, G. (eds.): Moments in Time. Papers Presented to Pál Raczky on His 60th Birthday. Ösrégészeti Tanulmányok/ Prehistoric Studies I. Budapest, 707-724.

CsÁNYI, M. - TÁRNOKI, J. 2013b: Túrkeve-Terehalom - a tell 2. települési szintje. Étkészlet a bronzkori házból (A Dinner Set from a Bronze Age House in Level 2 of the Túrkeve-Terehalom Settlement). Tisicum - A Jász-Nagykun-Szolnok megyei múzeumok évkönyve 22, 13-29.

DAszkiewicz, M. - Schneider, G. 2001: Klassifizierung von Keramik durch Nachbrennen von Scherben. Zeitschrift für Schweizerische Archäologie und Kunstgeschichte 58, 25-32.

Dietler, M. - Hayden, B. 2001: Feasts. Archaeological and ethnographic perspectives on food, politics, and power. Smithsonian Series in Archaeological Inquiry. Washington-London.

Dietrich, O. - Heun, M. 2012: The role of cult and feasting in the emergence of Neolithic communities. New evidence from Göbekli Tepe, south-eastern Turkey. Antiquity 86, 674-695.

Dinnyés, I. - Kỏvári, K - Lovag, Zs - Tettamanti, S - Topál, J. - Torma, I. (eds.) 1986: Pest megye régészeti topográfiája XIII/1. A budai és a szentendrei járás. Magyarország Régészeti Topográfiája 7. Budapest. 
EndRődi, A. - GyulaI, F. 1999: Soroksár-Várhegy (A Fortified Bronze Age Settlement in the Outskirts of Budapest). Communicationes Archaeologicae Hungariae, 5-24.

Fekete, Cs. 2005: The incrusted pottery at the Bronze Age settlement of Százhalombatta. In: PoroszLAI, I. - VICZE, M. (eds.): Százhalombatta Archaeological Expedition - SAX. Report 2 - Field Seasons 2000-2003. Emergence of European Communities Archaeological Research Report. Százhalombatta, 45-64.

P. Fischl, K. - Kiss, V. 2015: Exchange Networks in the Middle Bronze Age Carpathian Basin: The Movement of Visible and invisible Commodities. In: Suchowska-Ducke, P. - Reiter, S. S. VAndkilde, H. (eds.): Forging Identities. The Mobility of Culture in Bronze Age Europe. Report from a Marie Curie Project 2009-2012 with Concluding Conference at Aarhus University, Moesgaard 2012, Volume 1. British Archaeological Reports - International Series 2772. Oxford, 47-54.

P. Fischl, K. - Kiss, V. - Kulcsár, G. 1999: Kora és középső bronzkori település Baks-Homokbánya (Csongrád megye) lelőhelyen (Früh- und mittelbronzezeitliche Siedlungen auf dem Fundort Baks-Homokbánya (Komitat Csongrád). A Móra Ferenc Múzeum Évkönyve - Studia Archaeologica 5, 77-190.

P. Fischl, K. - KIss, V. - KulcsÁR, G. 2013: „Ahány ház, annyi szokás”? Specializált háztartások a Kárpát-medencei kora és középső bronzkorban ("So many households, so many customs”? Specialised households in the Carpathian Basin during the Early and Middle Bronze Age). Ósrégészeti Levelek - Prehistoric Newsletter 13, 255-269.

FüLöp, K. 2018: Why is it so rare and random to find pyre sites? Two cremation experiments to understand the characteristics of pyre sites and their investigational possibilities. Dissertationes Archaeologicae 3/6, 287-311.

FüLöp, K. 2016: Különleges késő bronzkori gyermeksír és miniatűr edénykészlete (A special Late Bronze Age child grave and its miniature vessel set). Tisicum - A fász-Nagykun-Szolnok megyei múzeumok évkönyve 2, 121-131.

FüLöp, K. - VÁczI, G. 2016: Late Bronze Age cremation burials: A complex event with few remains. Hungarian Archaeology E-fournal Spring, 1-7.

Geliebter, A. - Hashim, S. A. 2001: Gastric capacity in normal, obese, and bulimic women. Physiology \& Behavior 74, 743-746.

Geliebter, A. - Yahav, E. K. - Gluck, M. E. - Hasim, S. A. 2004: Gastric capacity, test meal intake, and appetitive hormones in binge eating disorder. Physiology \& Behavior 81, 735-740.

Gheorghiu, D. 2007: Between Material Culture and Phenomenology: The Archaeology of a Chalcholithic Fire-powered Machine. In: Gheorghiu, G. - NAsh, G. (eds.): The Archaeology of Fire. Understanding Fire as Material Culture. Budapest, 27-45.

Gheorghiu, D. 2008: Built to Be Burnt: The Building and Combustion of Chalcolithic Dwellings in the Lower Danube and Eastern Carpathian areas. In: Nikolova, L. - Merlini, M. - ComşA, A. (eds.): Circumpontica in Prehistory. Western Pontic Studies. Global Gratitude to Eugen Comşa for His 85th Birth Anniversary. Oxford, 55-68.

Gheorghiv, D. 2016: Building and Burning: The construction and Combustion of Chalcolithic Dwellings in the Lower Danube and the Eastern Carpathian Areas from the Perspective of Experimental Archaeology. In: Nikolova, L. - Merlini, M. - Alexandra, C. (eds.): Western-Pontic Culture Ambience and Pattern In memory of Eugen Comşa, Berlin-Boston, 33-52.

Gherdán, K. - Tóth, M. - Herbich, K. - Hajnalová, M. - Hložek, M. - Prokeš, L. - Mihály, J. HoRvÁth, T. 2010: Természettudományos megfigyelések a középső és késő rézkori kultúrák fazekasáruin Balatonöszöd-temetői dủlő lelőhelyen. Archeometriai Mühely, 83-104.

GogÂltan, F. 2012: Ritual Aspects of the Bronze Age Tell-Settlements in the Carpathian Basin. Ephemeris Napocensis 22, 7-56.

Gosselain, O. P. - Livingstone Smith, A. 2005: The source: clay selection and processing practices in 
Sub-Saharan Africa. In: Livingstone Smith, A. - Boseuest, D. - Martineau, R. (eds.): Acts of the XIVth UISPP Congress, University of Liége, Belgium, 2-8 September 2001. British Archaeological Reports - International Series 1349. Oxford, 33-47.

Gucsi, L. 2009: The Manufacturing techniques of the Grave pottery from Budakalász. In: BondÁR, M. Raczky, P. (eds.): The Copper Age cemetery of Budakalász. Budapest, 449-456.

GUCSI, L. IN PRINT: A másodlagosan égett kerámiák meghatározásának módszere és azok hamvasztásos temetkezésekben betöltött szerepének lehetséges értelmezései. Manuscript.

Hayden, B. 2014: The Power of Feasts: From Prehistory to the Present. New York.

Hoeck, V. - Ionescu, C. - Metzner-Nebelsick, C. - Nebelsick, D. L. 2012: Mineralogy of the ceramic slags from the Bronze Age funerary site at Lapus (NW Romania). Geological Quarterly 56, 649-664.

HoRvÁth, L. 1974: Őskori hordó alakú edény Szigligetről (A praehistoric barrel-shaped vessel from Szigliget). Archaeologiai Értesitó 101, 55-63.

IloN, G. 2012: A halomsíros kultúra rituális „edénydepója” Veszprém határából (The ritual „vessel hoard" of the Tumulus culture in the vicinity of Veszprém). In: Kisfaludi, J. (ed.): Régészeti kutatások Magyarországon 2010 (Archaeological Investigations in Hungary 2010). Budapest, 19-53.

ILON, G. 2014: Opfergrube der Hügelgräberkultur in der Gemarkung von Ménfőcsanak. Spiralornament auf einem Tonfries eines Gebäudes. Acta Archaeologica Academiae Scientiarum Hungaricae $65,5-42$.

Jaeger, M. - Kirleis, W. - Kiss, V. - Kulcsár, G. - Müller, J. - Staniuk, R. - Taylor, N. 2018: Kakucs Archaeological Expedition. In: Jaeger, M. - Kulcsár, G. - TAylor, N. - Staniuk, R. (eds.): Kakucs-Turján. a Middle-Bronze Age multi-layered fortified settlement in Central Hungary. Studien zur Archäologie in Ostmitteleuropa (Studia nad Paradziejami Europy Srodkowej) 18, 13-21.

Jaeger, M. - Kulcsár, G. 2013: Kakucs-Balla domb. A case study in the absolute and relative chronology of the Vatya culture. Acta Archaeologica Academiae Scientiarum Hungarica 64, 289-320.

KADA, E. 1909: Bronzkori urnatemető Vatyán (Pest m.) Archaeologiai Értesitő 29, 124-130.

KALICz-Schreiber, R. 1995: Bronzkori urnatemető Szigetszentmiklós határában (Das bronzezeitliche Urnengräberfeld von Szigetszentmiklós). Ráckevei Múzeumi Füzetek 2. Ráckeve.

Kalla, G. - Raczky, P. - V. Szabó, G. 2013: Ünnep és lakoma a régészetben és az írásos forrásokban. Az őskori Európa és Mezopotámia példái alapján. In: DÉRI, B. (ed.): Convivium. Budapest, 11-46.

Kiss, V. 2011: The role of the Danube in the Early and Middle Bronze Age of the Carpathian Basin. In: KovÁcs, Gy. - Kulcsár, G. (eds.): Ten Thousand years along the Middle Danube. Life and Early Communities from Prehistory to History. Varia Archaeologica Hungarica 26. Budapest, 211-239.

KIss, V. 2012: Middle Bronze Age encrusted pottery in Western Hungary. Varia Archaeologica Hungarica 27, Budapest.

KovÁcs, T. 1978: Középső bronzkori edénylelet Mogyoródról (Mittelbronzezeitliche Gefässfund aus Mogyoród). Archaeologiai Értesitón 105, 217-222.

KovÁcs, T. 1988: A face pot with dagger representation from Tószeg (Arcosedény Tószegről tőrábrázolással). Folia Archaeologica 39, 81-91.

Kreiter, A. 2005: Middel Bronze Age ceramic finds from Százhalombatta-Földvár, Hungary. In: PoRoszlai, I. - Vicze, M. (eds.): Százhalombatta Archaeological Expedition - SAX. Report 2 - Field Seasons 2000-2003. Emergence of European Communities Archaeological Research Report. Százhalombatta, 9-25.

Kreiter, A. 2006: Kerámia technológiai vizsgálatok a Halomsíros kultúra Esztergályhorváti-Alsóbárándpusztai településéről: hagyomány és identitás (Technological examination of Tumulus culture pottery from Esztergályhorváti-Alsóbárándpuszta: tradition and identity). Zalai Múzeum $15,149-170$.

KreIteR, A. 2007a: Kerámiatechnológiai tradíció és az idő koncepciója a bronzkorban. Ősrégészeti 
Levelek - Prehistoric Newsletter 8-9, 146-167.

Kreiter, A. 2007b: Technological Choices and Material Meanings in Early and Middle Bronze Age Hungary. Understanding the active role of material culture through ceramic analysis. British Archaeological Reports - International Series 1604. Oxford.

Kreiter, A. 2010: Kerámiavizsgálat. In: Pető, Á. - Kreiter, A. (eds.): Mikroszkóppal a régészet szolgálatában. A Kulturális Örökségvédelmi Szakszolgálat Alkalmazott Természettudományi Laboratóriumában végzett természet- és környezettudományos vizsgálatok bemutatása. Budapest, 66-77.

Kreiter, A. - Bajnóczi, B. - Sipos, P. - Szakmány, Gy. - Tóth, M. 2007: Archaeometric examination of Early and Middle Bronze Age ceramics from Százhalombatta-Földvár, Hungary. Archeometriai Mühely 2, 33-47.

Kulcsár, G. 1997: Adatok a Dél-Alföld kora bronzkori történetéhez (Hódmezővásárhley - Barci-rét kora bronzkori települése 1.) In: HAVAssy, P. (ed.): Látták Trója kapuit. Bronzkori leletek a KözépTisza vidékéröl. Gyulai katalógusok 3. Gyula, 13-56.

Kulcsán, G. 2009: The Beginnings of the Bronze Age in the Carpathian Basin. The Makó-Kosihy-Čaka and the Somogyvár-Vinkovci cultures in Hungary. Varia Archaeologica Hungarica 23. Budapest.

Lőrinczy, G. - Trogmayer, O. 1995: Birituális vatyai temető Csanytelek-Palén (Birituales Gräberfeld der Vatya-Kultur in Csanytelek-Palé). A Móra Ferenc Múzeum Évkönyve - Studia Archaeologica 1, 49-65.

Marosi, A. 1930: A pákozdvári őstelep. Archaeologiai Értesítő 44, 53-73.

Michelaki, K. 2006: Household Ceramic Economies. Production and consumption of household ceramics among the Maros villagers of Bronze Age Hungary. British Archaeological Reports - International Series 1503. Oxford.

MichelAKI, K. 2008: Making pots and potters in the Bronze Age Maros Villages of Kiszombor-Új-Élet and Klárafalva-Hajdova. Cambridge Archaeological fournal 18, 335-380.

NYírI, B. 2013: Domb tetején kicsi ház - egy kora bronzkori házbelső edénykészletének vizsgálata Dunaújváros-Rácdomb tell-telepéről (Little house on the hilltop - analysis of a household ceramic assemblage from the tell settlement of Dunaújváros-Rácdomb). Ösrégészeti Levelek - Prehistoric Newsletter 13, 163-177.

Ortutay, Gy. 1977: Magyar néprajzi lexikon. Első kötet: A - E 1. Budapest.

PalÁtová, H. - SAlaš, M. 2002: Depoty keramických nádob doby bronzové na Morave a v sousedních zemích (Bronzezeitliche Gefässdepotfunde in Mähren und benachbarten Gebieten). Pravek Supplemetum 9. Brno.

Pollock, S. 2015: Between Feasts and Daily Meals. Towards an archaeology of commensal spaces. Berlin Studies of the Ancient World 30. Berlin.

PoroszlaI, I. 1988: Preliminary report about the excavation at Nagykőrös-Földvár (Vatya-culture). Stratigraphical data and settlement structure. Communicationes Archaeologicae Hungariae, 29-39.

Poroszlai, I. 1992: Százhalombatta-Földvár. In: Meier-Arendt, W. (ed.): Bronzezeit in Ungarn. Forschungen in Tell-Siedlungen an Donau und Theiss. Frankfurt am Main, Budapest, 153-155.

PoroszlaI, I. 2000a: Excavation campaigns at the Bronze Age tell site at Százhalombatta-Földvár I. 1989-1991; II. 1991-1993. In: Poroszlai, I. - Vicze, M. (eds.): Százhalombatta Archaeological Expedition - SAX. Annual Report 1 - Field Season 1998. Százhalombatta, 13-74.

Poroszlat, I. 2000b: Die Grabungen in der Tell-Siedlung von Bölcske-Vörösgyürű (Kom. Tolna) (19651967). Acta Archaeologica Academiae Scientiarum Hungaricae 51, 111-145.

Poroszlai, I. - Vicze, M. (eds.) 2004: Százhalombatta története a bronzkortól napjainkig. A Százhalombatta „Matrica” Múzeum állandó kiállításának katalógusa. Százhalombatta.

RepisZky, T. 2004a: Budajenő, Hegyi-szántók. Régészeti Kutatások Magyarországon 2002 (Archaeological Investigation in Hungary 2002). Budapest, 184. 
Repiszky, T. 2004b: Budajenő, Hegyi-szántók. Régészeti Kutatások Magyarországon 2003 (Archaeological Investigation in Hungary 2003). Budapest, 168.

Richards, C. - Thomas, J. 1984: Ritual activity and structured deposition in Later Neolithic Wessex. In: Bradley, R. - Gardiner, J. (eds.): Neolithic Studies: a Review of Some Current Research. British Archaeological Reports - International Series 133, 189-218.

SÁNTA, G. IN PRINT: Rituális (közösségi) cselekvéssorok nyomai Domaszék-Börcsök tanyán, a halomsíros kultúra településén. Manuscript.

Sofaer, J. 2015: Clay in the Age of Bronze. Essays in the Archaeology of Prehistoric Creativity. New York.

SpATzIER, A. 2017: Detecting deliberate fragmentation at a circular enclosure from the late 3rd millenium BC. Calculating fragmentation and refitting analysis of ceramic finds from Pömmelte-Zackmünde, Saxony-Anhalt, Germany. Praehistorische Zeitschrift 92, 370-386.

Stapel, A. 1999: Bronzezeitliche Deponierungen im Siedlungsbereich. Altdorf-Römerfeld und Altheim, Landkreis Landshut. Tübinger Schriften zur Ur- und Frühgeschichtlichen Archäologie 3. New York-München-Berlin.

Stevanović, M. 1997: The age of clay: the social dynamics of house destruction. fournal of Anthropological Archaeology 16, 334-395.

V. SzABó, G. 2004: A tiszacsegei edénydepó. Újabb adatok a Tisza-vidéki késő bronzkori edénydeponálás szokásaihoz (Das Gefässdepot von Tiszacsege. Neue Angaben zur Sitte der spätbronzezeitlichen Gefässdeponierungen in der Theissgegend). A Móra Ferenc Múzeum Évkönyve - Studia Archaeologica 10, 81-113.

SzABó, G. - HAjDu, T. 2011: A mészbetétes edények díszítésének szimbolikája a bonyhádi vegyes rítusú bronzkori temető embertani leleteinek feldolgozása tükrében (Symbolism of the ornaments of encrusted pottery in the light of anthropological finds from the Bronze Age mixed-rite cemetery at Bonyhád). Anthropologiai közlemények 52, 85-108.

SzABó, N. 2018: Budajenő, Hegyi-szántók középső bronzkori településének vizsgálata. MA Thesis. Eötvös Loránd University, Budapest.

SZATHMÁRI, I. 2009: Megjegyzések a bronzkori háztartások edénykészletéről (Ammerkungen zur Gefässensembles bronzezeitlicher Haushalten). Tisicum - A fász-Nagykun-Szolnok megyei múzeumok évkönyve 19, 295-307.

SzEverÉNYI, V. 2013: Bronzkori „háztűznéző”: szándékos házégetés és anyagi metaforák a Kárpát-medence kora és középső bronzkorában (Deliberate house-burning and material metaphors in the Early and Middle Bronze Age of the Carpathian Basin). Ösrégészeti levelek (Prehistoric Newsletter) 13, 215-232.

Szeverényi, V. - Kulcsár, G. 2012: Middle Bronze Age Settlement and Society in Central Hungary. In: Jaeger, M. - Czebreszun, J. - P. Fischl, K. (eds): Enclosed Space - Open Society. Contact and Exchange in the Context of Bronze Age Fortified Settlements in Central Europe. Studien zur Archäologie in Ostmitteleuropa 9. Bonn, 287-351.

Tóтн, K. 1999: Kora bronzkori edénylelet Kecskemét-Csukáséren (Ein frühbronzezeitliches Gefässdepot auf dem Fundort Kecskemét-Csukásér). A Móra Ferenc Múzeum Évkönyve - Studia Archaeologica 5, 27-49.

Tringham, R. 2005: Weaving house life and death into places: a blueprint for a hypermedia narrative. In: Bailey, D. - Whittle, A. - Cummings, V. (eds.): (Un)settling the Neolithic. Oxford, 98-111.

VÁczI, G. 2003: Adatok Velence és Velencefürdő középső bronzkori történetéhez. Ösrégészeti Levelek (Prehistoric Newsletter) 5, 41-51.

VÁczI, G. 2004: Pákozd-Várhegy. Középső bronzkori erődített telep a Velencei-hegységben. MA Thesis. Eötvös Loránd University, Budapest.

Vicze, M. 1992: Baracs-Földvár. In: MeIer-Arendt, W. (ed.) Bronzezeit in Ungarn. Forschungen in Tell Siedlungen an Donau und Theiss. Frankfurt am Main-Budapest, 146-148. 
Vicze, M. 2011: Bronze Age Cemetery at Dunaújváros-Duna-dúlő. Dissertationes Pannonicae 4/1. Budapest.

VICzE, M. 2013a: Százhalombatta-Földvár néhány bronzkori háztartásáról (Some aspects of households at the Bronze Age tell of Százhalombatta-Földvár). Ösrégészeti Levelek - Prehistoric Newsletter $13,178-189$.

Vicze, M. 2013b: Middle Bronze Age Households at Százhalombatta-Földvár. In: Anders, A. - Kul-csár, G. - Kalla, G. - Kiss, V. - V. Szabó, G. (eds.): Moments in Time. Papers Presented to Pál Raczky on His 60th Birthday. Ösrégészeti Tanulmányok - Prehistoric Studies 1. Budapest, 757-770.

Wieszner, B. 2016: A Vatya-kultúra koszideri korú dél-alföldi területi csoportjának temetkezései. BA Thesis. Szeged.

ZALOTAY, E. 1957: Kelebiai bronzkori temető. Régészeti Füzetek 6.

\section{Catalogue - Description of ceramics}

1. Cup (Fig. 18.3)

Its base is flat, the belly is rounded, the neck is slightly narrowing, almost cylindrical. Its rim is straight. The interior surface is uneven as the result of pinching.

Showing signs of moderate and slight secondary burning. On the rim, a 'V'-shaped breakage existed before or generated during the secondary burning, with a vertical crack running from the lower tip of the ' $\mathrm{V}$ ' to the base of the cup, and slightly opened by deformation at its higher part. The fracture at the join of the rim and the upper part of the handle happened after the secondary burning event but before the deposition of the cup (Fig. 39.1). The breakage on the lower part of the handle is recent.

Represents $90 \%$ of the vessel ${ }^{106}$; Potter: Level 3; dB.: $3.8 \mathrm{~cm}$; dR.: $6.2 \mathrm{~cm}$; H.: $6.5 \mathrm{~cm}$; tW.: $3-5$ mm. ${ }^{107}$

\section{Cup (Fig. 18.4)}

Two fragments of a cup. The base has an omphalos, the lower part is rounded. The belly is slightly profiled, angular. The neck is almost cylindrical. The rim diameter is smaller than the belly. The shoulder is decorated with a horizontal, thin, incised line.

Showing signs of moderate secondary burning. The breakages happened after the exposure to heat.

Represents 20\% of the vessel; Potter: Level 5; dB.: $1 \mathrm{~cm}$; $5.4 \mathrm{~cm}$; H.: $6.6 \mathrm{~cm}$; tW.: 3-5 mm.

\section{Mug (Fig. 12.a, Fig. 19.1)}

The base is flat, but convex inside. The lower part of the vessel's body is rounded. The belly is slightly profiled in section, $1 \mathrm{~cm}$ lower at the handle than the opposite side. The shoulder connects with an unbroken curve to the neck. The rim is everted. The handle arches between the shoulder-neck joint and the rim. The rim, right above the handle, is slightly concave, shaped in a manner of ansa lunata. The handle is irregular in shape, slightly curved and placed diagonally on the vessel.

Showing signs of moderate secondary burning.

Represents 70\% of the vessel; Potter: Level 3; dB.: $4.5 \mathrm{~cm}$; dR.: $8.5 \mathrm{~cm}$; H.: $9.3 \mathrm{~cm}$; tW.: 7-5 mm.

\section{4. $M u g$ (Fig. 17.6)}

Omphalos on the base. The belly is emphasised on the biconical body, located below the midline of the body. Shoulder is strongly curved. The shoulder and neck meet in a strongly profiled line. The neck is curved, the rim is strongly everted and thickened. There is a small ornament constructed of triple ' $\mathrm{V}$ 'shaped motifs on the top of the shoulder. The motifs were created by impressions of a pointed tool; a characteristic technique associated with the Transdanubian Encrusted Pottery culture. The shape and proportions of the vessel differ slightly from the typical Vatya form.

106 Estimated values.

107 Abbrevations: dB.: diameter of Base, dR.: diameter of Rim, tW.: thickness of Wall , H.: Height, (r).: reconstructed. 
Showing signs of moderate secondary burning. The breakages happened after being exposed to heat, except two cracks, one running from the rim vertically $2.6 \mathrm{~cm}$ deep, the other over the belly running horizontally, probably due to secondary burning.

Represents $40 \%$ of the vessel; Potter: Level 5; dB.: 4 cm; dR.: 10.7 cm; H.: 9 cm; tW.: 3-5 mm.

\section{5. fug (Fig. 11.b, Fig. 20.1)}

Omphalos on the base. On the lenticular, biconical body, the belly's profile was emphasized by a strong line, slightly below the midline. The shoulder-neck joint is also lightly pronounced. The rim is slightly inwards turning, incomplete. The handle sits on the upper third of the shoulder. Above the line of the belly the vessel is ornamented with a double line of horizontal channelling. In between the channels eight groups of three impressed lenticular dots are placed. There are four garland ornaments on the shoulders, made up of three smoothed lines. Above the peaks of the garlands there are three impressed lenticular dots arranged horizontally. A cluster of three vertical smoothed lines hang from the upper joints of the garlands. It is possible that the lower end of these lines finished in three lenticular dots based on the design of another fragment (Vessel 6). Also below the lowest point of the garlands' curve three impressed lenticular groups of dots can be seen arranged horizontally. The edge of the base is slightly worn.

The exterior shows signs of slight secondary burning, the fractures on the object occurred after its exposure to heat.

Represents 50\% of the vessel; Potter: Level 5; dB.: $4.6 \mathrm{~cm}$; H(r):: $13.8 \mathrm{~cm}$; tW.: 4-6 mm.

\section{Jug (Fig. 20.2, Fig. 39.2)}

The object is essentially the „identical twin” of the former (Vessel 5), although there are a few different details. The lenticular body is slightly more pressed. The belly is almost biconical, the midline runs exactly halfway between the base and the neck. The shoulder-neck joint in this case is not emphasised by line, the transition is smooth. Some elements of the decoration are different: the cluster of three lenticular impressed dots below the garland motifs are not completely horizontal.

The exterior shows signs of slight secondary burning, the fractures on the object occurred after its exposure to heat. On the lower half of the vessel the exterior is scarred in two places due to thermal-shock. The larger scar is $6 \mathrm{cms}$ in diameter, from the belly to the base.

Represents $40 \%$ of the vessel; Potter: Level 5; dB.: 4.7 cm; H.: 9 cm; tW.: 4-6 mm.

\section{Fug (Fig. 11.a, Fig. 21.1)}

Omphalos on the base. The body of the vessel is pressed, the belly is located at the lower third of the body. Neck, rim, and handle are missing. There are four, slightly downward pointing and horizontally stretched, oval knobs on the belly. On the shoulder there are four garland ornaments. The garlands were made by two smoothed lines and their peak is at the midline of the shoulder. Above the peaks, there are downward pointing triangular motifs consisting of lenticular dots. Below the bottom of the garlands' curve, there are three vertical smoothed lines on each side of the four knobs. However, on each side of the knob situated under the handle, there are only two such vertical lines. The shoulder and neck meets in a horizontally smoothed line. The wall thickness and the proportions of this jug revoke the characteristics of the Transdanubian Encrusted Pottery Culture.

The upper part of the body along the neckline is damaged intentionally (Fig. 8.a). The base of the vessel shows signs of wear. The tips of all four knobs are strongly worn (Fig. 7.a).

Represents $50 \%$ of the vessel, but it was already broken by the time of deposition - the estimate considered the whole jug. Potter: Level 5; dB.: $3 \mathrm{~cm} ; \mathrm{H}(\mathrm{r}) .: 7.2 \mathrm{~cm}$; tW.: 2-3 mm.

\section{Fug (?) (Fig. 22.1)}

Omphalos on the base. On the biconical body, the belly is profiled slightly in the line of its upper third. The shoulder-neck joint is emphasized by a horizontally smoothed line. The neck and the rim are missing. 
The exterior shows signs of moderate secondary burning. On the lower half of the vessel the exterior is scarred in several places due to thermal-shock.

Represents $20 \%$ of the vessel; Potter: Level 4 or 5; dB.: 5 cm; H(r).: $4.2 \mathrm{~cm}$; tW.: 3-7 mm.

9. Fug (Fig. 22.2)

Belly and shoulder fragment of a jug. The belly has a slight edge. The shoulder is decorated with a garland consisting of four smoothed lines. Underneath the peak of the garland's curves, there was probably a motif consisting of three impressed lenticular dots, but only one of the dots is partially visible. The lower parts of the garlands are straight, parallel to the belly's line.

Potter: Level 4 or 5 ; tW.: 2-3 mm.

10. Jug (Fig. 19.5)

A big sherd of a jug with handle. The body was slightly profiled in line at the shoulder- neck joint. The belly was probably rounded. The rim is slightly everted. The handle sits on the shoulder and is attached to the rim. The clay is richly tempered with fine mica, which is different from the rest of the finds.

Represents 5\% of the vessel; Potter: Level 3; tW.: 4-5 mm.

\section{1. $M u g$ (Fig. 21.2)}

A sherd of a jug. Based on its reconstructable dimensions, the belly is biconical and rounded, decorated in its upper half with a garland consisting of three smoothed lines. Below the bottom of the garlands' curve, groups of three lenticular impressed dots were arranged horizontally - only partially preserved. The decorations were carelessly executed.

Showing signs of moderate secondary burning.

Represents 5\% of the vessel; Potter: Level 3; tW.: 5-6 mm.

\section{Small jug (Fig. 19.3)}

Its base is flat, the rounded belly is located on the lower third of the body. The neck and the rim is straight. The handle is missing, but it was connected to the rim.

Severely secondarily burnt, distorted object. The jug was in a horizontal position while exposed to heat, as the base of the object slightly warped. Just above the edge of the base, there is a large blister in one place. Its burnished surface is peeling off in places. The neck-rim fragment is strongly folded. Breakages occurred after the exposure to secondary heat, and a deliberate cracking sequence of $4 \mathrm{~cm}$ is detectable near the base.

Represents 30\% of the vessel; Potter: Level 2 or 3; dB.: 5.5 cm; dR.: 9 cm; H.: $10.1 \mathrm{~cm}$; tW.: 5-10 mm.

\section{Jug (Fig. 24.3)}

Fragment of neck-rim of a jug. Its entire exterior surface is uneven.

Showing signs of moderate secondary burning. The fractures occured after the exposure to secondary heat.

Represents $10 \%$ of the vessel; Potter: Level 2; dR.: $10.5 \mathrm{~cm}$; tW.: $5 \mathrm{~mm}$.

14. Fug (Fig. 24.2)

A neck-rim fragment of a jug, with the beginning of an ansa lunata at the edge of the rim.

Showing signs of severe secondary burning. The handle-side became blistered due to exposure to heat, its walls swelled to twice of their original thickness.

Represents 5\% of the vessel; Potter: Level min. 3; dR.:13 cm; tW.: 3-5 mm.

15. Jug (Fig. 24.1)

Fragment of a jug of neck-rim. An ansa lunata design can be observed on the handle where it joins the rim. 
Showing signs of slight secondary burning. The breakages occurred after being exposed to heat. Both of the top corners of the ansa lunata were damaged, but before the secondary burning took place.

Represents 5\% of the vessel; Potter: at least Level 3; dR.: $10 \mathrm{~cm}$; tW.: 3-4 mm.

16. Jug (Fig. 12.b, Fig. 19.4)

The rounded belly is located in the lower third of the body. The shoulder-neck transition is profiled at a slight edge. There are three horizontally stretched knobs on this profiled line. The knobs are notched vertically. One of the three knobs is vis-à-vis with the handle, while the other two are close to the handle, so that the knobs are placed in a 120 degree to each other. An ansa lunata-type handle sits in the shoulder-neck joint. On the interior surface of the belly there is an inprint of a grain.

Almost all of the vessel showed signs of moderate secondary burning. On the left side of the handle, however, it is burnt severely - here, the ceramic structure expanded. The smoothed surface flaked off in several places. Some of the fractures could have been occurred before it was fired originally or during the secondary burning event, but others occurred definitely after being exposed to secondary heat. At the height of the belly, there is a breakage which shows traces left by at least two intentional blows. The breakage suggests that the blows came from the direction of the vessel's interior after the secondary burning event, resulting in a flaked fan-like surface (Fig. 8.b).

Represents 70\% of the vessel; Potter: Level 4; dB.: $10 \mathrm{~cm}$; H(r):: $21.6 \mathrm{~cm}$; tW.: 5-8 mm.

\section{Bowl (Fig. 17.4)}

Fragments of the rim and the belly of a bowl. The outer side of the strongly thickening rim is curved while the upper part has a strongly profiled edge. The shoulder-neck joint is divided by a horizontal line. Right under the line, runs a row of small lenticular dots. Below this further lenticular impressed dots are arranged in downward-facing triangular motifs.

Showing signs of moderate secondary burning. The break-surface, which runs vertically $3.5 \mathrm{~cm}$ down from the rim occurred due to exposure to secondary heat, while the other fractures afterwards.

Represents 20\% of the vessel; Potter: Level 5; dR.: $19.4 \mathrm{~cm}$; tW.: $5 \mathrm{~mm}$.

\section{Bowl (Fig. 17.5)}

Fragment of the rim and belly of a bowl, with a handle. Similar to the previous object. The outer side of the strongly thickening rim is curved while the upper part has a strongly profiled edge. The hourglass-shaped handle is decorated by an ansa lunata motif. Under the handle, there is a wide, horizontal channelled line.

Showing signs of moderate secondary burning. The break-surface, which runs vertically $3.5 \mathrm{~cm}$ down from the rim occurred due to exposure to secondary heat, while the other fractures afterwards.

Represents 5\% of the vessel; Potter: Level 4 or 5; dR.: $19.6 \mathrm{~cm}$; tW.: $5 \mathrm{~mm}$.

\section{Bowl (Fig. 11.c, Fig. 17.3)}

Oval bowl with a flat base, everted wall, and straight rim. The outer side of the rim is decorated with a slightly upward standing, pointed set of three knobs.

The interior surface is moderately worn. The exterior is yellow, with possible traces of secondary burning.

Prepresents 50\% of the vessel; Potter: Level 3; dB.: 9×11 cm; dR.: $13.5 \times 16.5 \mathrm{~cm}$; H.: $4.5 \mathrm{~cm}$; tW.: 5-11 mm.

\section{Bowl (Fig. 17.1)}

Fragment of a conical bowl. Its rim is thickened on the inside. On the outside of the rim there are a pair of knobs. Both surfaces are black, nicely burnished.

Represents $10 \%$ of the vessel; Potter: Level 4; dR.: $27.5 \mathrm{~cm}$; tW.: $8 \mathrm{~mm}$. 


\section{Bowl (Fig. 17.2)}

Oval bowl with a flat base, everted wall, and straight rim. It is characterized mainly by the irregularity of its exterior surface, due to areas left unsmoothened. It is black on the outside with a yellow patch. Possibly slightly secondarily burnt.

Represents $20 \%$ of the vessel; Potter: Level 2; dB.: $4.5 \times 7$ cm; dR.: $10 \times 12.5$ cm; H.: 3 cm; tW.: 5-10 mm.

\section{Bowl (Fig. 38.2)}

Fragment of a conical bowl. The rim has a thickened lip, forming a ' $\mathrm{T}$ ' in cross-section.

Showing traces of moderate secondary burning. The right side of the fragment, which is curved and extends from the rim to the lower horizontal fracture, is strongly worn (abraded?). The left vertical breakage was created after the secondary burning. Its entire surface is strongly worn. The fragment belongs to an Early Bronze Age bowl.

dR.: $27 \mathrm{~cm}$; tW: $5 \mathrm{~mm}$.

\section{Pot? (Fig. 38.3)}

Shoulder fragment of an unidentifiable ceramic vessel with a pair of round double knobs. The righthand vertical breakage is visibly rounded, worn out (abraded?). It originates from an earlier period than the rest of the assemblage, probably associated with the Early Bronze Age.

tW.: 6-8 mm.

\section{Pot (Fig. 33.1)}

The pot has an elongated, ovoid shape, the belly is below the midline of the body. Its rim is strongly thickened, with four large, triangular knobs facing downwards. Its outer surface is untreated.

Shows signs of severe secondary burning, slightly distorted in one place. Its surface is cracked in a web-like pattern at many places. One knob is broken off before the exposure to secondary heat, this fracture surface is rounded, worn (Fig. 7.d). Some of its fractures occurred after the secondary burning, while others during or before the event.

Represents $20 \%$ of the vessel; Potter: Level 4; dR.: $22 \mathrm{~cm}$; tW.: 9-13 mm.

\section{Pot (Fig. 34.1)}

Squat vessel, the belly is slightly below the midline. The rim is thickened, and there is a large, horizontally stretched knob applied to it. (Originally there were four, according to similar vessels of this type.) The outer surface is untreated, moderately rough. In the base on the interior, some kind of a charred organic residue can be detected.

Represents 30\% of the vessel; Potter: Level 4; dB.: $14 \mathrm{~cm}$; dR.: $34 \mathrm{~cm}$; tW.: 8-12 mm.

\section{Pot (Fig. 35.3)}

The pot has an elongated, ovoid shape, the belly is below the midline of the body at the lower third of the pot. Its rim is strongly thickened, with four large triangular knobs facing downwards. Attached to the lower half of the knobs, there are diagonal, downwardly tapering ribs with notched on the neck. Untreated exterior.

Shows signs of severe secondary burning, several sherds were slightly distorted. The vessel surface is cracked in a web-like patterns at some places (Fig. 40.1). Some fractures occurred before or during the secondary burning event, but most of them afterwards. In the middle of the neck, $3.5 \mathrm{~cm}$ below the rim, a blow carried out with a pointed implement on the exterior resulted in a fan-shaped chip on the interior. The tip of one of the knobs was slightly chipped, and its damaged surface was worn before its secondary exposure to heat.

Represents 30\% of the vessel; Potter: Level 4; dB.: 11 cm; dR.: 21.5 cm; H.: 32.5 cm; tW.: 6-8 mm. 


\section{Large pot (Fig. 37.1)}

The rim fragment of an unusually large pot. The rim is thick and strongly profiled. On the lower edge of the rim there is a downward facing triangular knob. The interior surface of the rim is faceted.

Many of its sherds show signs of severe secondary burning and are distorted, vitrified or slag-like.

Represents 10\% of the vessel; Potter: Level 5; dB.: 15 cm; dR.: 39 cm; tW.: 7-15 mm.

\section{Large pot (Fig. 35.2)}

Rim fragment of a very large pot. At the lower edge of the thickened, profiled rim, a slightly protruding knob sits. Under that, a short rib placed left of the knob, is arranged diagonally and decorated with finger-impressions.

Showing signs of severe secondary burning (Fig. 13.b). On the left edge of the fragment the clay began to blister due to exposure to secondary heat. The two vertical fractures occurred before or during the secondary burning event, but the lower breakage, parallel to the rim happened later.

Represents 5\% of the vessel; Potter: Level 4; dR.: $32 \mathrm{~cm}$; Fv.: 10-15 mm.

\section{Large pot (?) (Fig. 32.3)}

Slightly everted rim fragment of a large pot.

Shows signs of moderate secondary burning, which can be observed on all fracture surfaces. None of the breakages occurred after the secondary burning event.

Represents 5\% of the vessel; Potter: Level 4; dB.: $34 \mathrm{~cm}$; tW.: 14-15 mm.

\section{Pot (Fig. 35.1)}

Rim and shoulder fragment of a pot. The neck is almost cylindrical. The neck and shoulder transition is not shaped like an ' $\mathrm{S}$ ' form as usual to similar types of vessels, but instead it forms an angle. The rim is slightly everted, with a wide, vertically notched rib running beneath it.

Showing signs of severe secondary burning. At top right side of the fragment, the clay began to blister, turned into a vitrified, slag-like consistency with swollen vessel-walls (Fig. 13.c).

Represents 5\% of the vessel; Potter: Level 4; dR.: $22 \mathrm{~cm}$; tW.: 5-6 mm.

\section{Pot (Fig. 35.4)}

Rim and shoulder fragment of a pot. The neck and shoulder transition is not shaped like an ' $\mathrm{S}$ ' form as usual to similar types of vessels, but instead it forms an angle. The rim is slightly everted, funnelled. The neck is almost cylindrical. The rim is profiled and a very wide knob sits on it.

Shows signs of severe secondary burning. All fracture surfaces came about as a result of the exposure to secondary heat.

Represents 5\% of the vessel; Potter: Level 3; dR.: $15 \mathrm{~cm}$; tW.: 7-9 mm.

\section{Pot (Fig. 35.5)}

Base fragment of a pot with vertical traces of smoothing.

Showing signs of severe secondary burning, distorted, partially covered by web-like cracks. The fractures occurred both before and after the exposure to secondary heat.

Represents $10 \%$ of the vessel; Potter: Level 3; dB.: $10 \mathrm{~cm}$; tW.: 7-9 mm.

\section{Large, deep bowl (Fig. 29.2)}

The belly-line is in the upper third of the body. The neck is connected to the shoulder by a curved transition. The rim is slightly thickened. The two handles sit on the shoulder and join the rim from below. There are six large, round but pointed knobs on the shoulder. Two are perpendicular to the handles' axis, the other four are close to the handles. The exterior surface is left untreated under the belly, slightly coarse. Above the belly it is smoothed, burnished. At the height of the shoulder-neck 
junction, it is profiled inside with a slight edge.

Showing signs of slight/moderate secondary burning. Its fractures occurred after the exposure to secondary heat. The tip of the middle knob is worn. On the interior between in a $10 \mathrm{~cm}$ wide band from the base the surface is eroded.

Represents 60\% of the vessel; Potter: Level 4; dB.: $12 \mathrm{~cm}$; dR.: 39 cm; H.:33 cm; tW.: 8-10 mm.

\section{Large, deep bowl. (Fig. 29.1, Fig. 40.2)}

The belly-line is in the upper third of the body. The neck is connected to the shoulder by a curved transition. The rim is slightly thickened. Originally, two handles rest on the shoulder-neck joint and join the rim from below. There are six large, round but pointed pairs of knobs on the shoulder. Two pairs in the position perpendicular to the handles' axis and four pairs close to the handles. The exterior surface is left untreated under the belly, slightly coarse. Above the belly it is smoothed, burnished.

Shows signs of moderate secondary burning. The handle was broken off before the exposure to secondary heat. The break-surfaces of the restored part of the bowl were also burnt secondarily. Other breakage lines occurred after the secondary burning event. The handles were attached to the vessel body with the dowel-joint technique at both ends.

Represents 20\% of the vessel; Potter: Level 4; dR.: $41 \mathrm{~cm}$; tW.: 8-10 mm.

\section{Deep bowl (Fig. 30.2, Fig 39.3)}

The belly-line is in the upper third of the body. The neck is connected to the shoulder by a curved transition. The rim is thickened and profiled. Originally, two handles rested on the shoulder and joined the rim from below. At the belly-shoulder joint an edge was formed by it being horizontally smoothened. The exterior of the object under this line is left untreated, slightly rough, above it is smooth and burnished. A row of small lenticular dots are running right below the shoulder-belly joint. Criss-crossing combed bundles of lines motifs cover the lower third of the body made by a four-toothed comb-like implement.

Showing signs of moderate secondary burning. The fractures occurred before and during the exposure to secondary heat. The handle and a larger fragment during this event were separated from the rest of the object, thus these oxidized in different ways, resulting in different colours of matching sherds. The interior surface peeled off in a scale-like manner, probably as the result of an interaction with some kind of acidic material. This eroded surface later became worn at some parts.

Represents 30\% of the vessel; Potter: Level 5; dR.: $33 \mathrm{~cm}$; tW.: 6-8 mm.

\section{Deep bowllos (Fig. 13.a, Fig. 31.1)}

The belly-line is in the upper third of the body. Compared to the other deep bowls, it is slightly more profiled. The rim is slightly thickened and profiled. Two handles rest on the shoulder-neck joint and join the rim from below. At the belly-shoulder joint an edge was formed by a horizontally smoothed line. The exterior surface under this line is left untreated, slightly rough, with marks of smoothening applied during the shaping of the vessel. Above that edge, the neck and the rim is smoothed and burnished on the interior as well. On the shoulder, under the smoothed line, a horizontally elongated, oval-shaped knob sits perpendicular to the axis of the handles. On the opposite side of the object, however there are two knobs close to each other instead of one. Between the handles and the knobs, right under the smoothed edge, horizontal line bundles decorate the shoulder created by a three-toothed comb-like implement. Besides the handles and the knobs, the bundles of lines turn in a 90 degree angle, before running all the way down to the base. In this way the bundles of lines form a 'frame' between the knobs within which located two more vertical line bundles.

The entire object show signs of severe secondary burning and is strongly deformed. It is strongly warped in some parts while opened along the cracks in others. The interior surface from the base up to the height of $8 \mathrm{cms}$ is strongly eroded, which is particularly visible in the area of the base where

108 The drawn shape of the vessel is a reconstruction, based on an undestorted part of the cross-section. 
a layer of 1-2 mms had been eroded away. Up to the neck, the interior surface peeled off in a scalelike pattern in patches. On the rim, a large chipped area existed prior to the secondary heat exposure, other fractures mostly happened after it, except for the cracks. The eroded surface on the interior also occurred before the secondary burning event; all cases described here related to use-wear.

Represents $60 \%$ of the vessel; Potter: Level 4; dB.: 10-10.5 cm; dR.: 33 cm; H.: $26.5 \mathrm{~cm}$; tW.: 6-10 mm.

\section{Deep bowl (Fig. 31.2)}

A slightly elongated vessel with the belly-line in the upper third section. The rim is thickened and profiled strongly. Two handles rest on the shoulder and connect to the rim from below. At the shoulder-neck joint it is divided by a horizontally smoothed edge. Underneath this line the surface of the object is slightly rough, but close to the base, smoothed to a height of $5 \mathrm{cms}$. Above the smoothed edge the surface is smoothened and burnished. On the shoulder, under that smoothened line, a horizontally elongated, oval-shaped knob sits perpendicular to the axis of the handles. Small lenticular impressed dots are running right under the smoothed edge on the shoulder between the handles and the knobs. The vessel shows signs of moderate secondary burning, which is more severe on the handle and belly. At these places the clay body began to blister, turned into a vitrified, slag-like texture and with swollen vessel-walls. Its fractures occurred before, during and after the fire. Marks of several blows can be noticed on the object. One in the lower section of the vessel, where the object was clearly hit from the outside with considerable force.

Represents 20\% of the vessel; Potter: Level 5; dB.: $10.3 \mathrm{~cm}$; dR.: $31 \mathrm{~cm}$; H.: $30 \mathrm{~cm}$; tW.: 7-10 mm.

\section{Large deep bowl (Fig. 36.2)}

The neck is slightly elongated. The rim is thickened and profiled. Originally, two handles rested on the shoulder-neck joint and were attached to the rim from below. At the shoulder-neck joint the vessel is divided horizontally by a smoothed edge. A series of large impressed, lenticular dots are placed exactly on the edge of the smoothed line.

Shows signs of moderate secondary burning, one small fragment is severely burnt. The large segment of the vessel - now consisting of several pieces, including the handle - came into contact with the fire in this form, suggested by the oxidized outer breakage surfaces. Other fractures, including the inner breakages of that large fragment, occurred after the secondary burning event.

Represents $10 \%$ of the vessel; Potter: Level 4; dR.: $41 \mathrm{~cm}$; tW.: 8-10 mm.

\section{Deep bowl (Fig. 30.1)}

Spherical bowl. It has a rounded, slightly profiled belly, with a mid-line about half way up the object. The neck is connected to the shoulder by a curved transition. The rim is thickened and profiled. Originally two handles rested on the shoulder-neck joint and were attached to the rim from below. At the neck-shoulder joint the vessel is divided horizontally by a smoothed edge. On this edge sits a horizontally elongated, oval-shaped but upwards pointing knob. Based on the existing fragments, the bowl could originally have had four such knobs, their position was 90 degrees relative to each other, but with the handles they sat in a 45 degree angle. A series of large impressed lenticular dots are running right under the smoothened edge, between the knobs and the handles. The surface of the vessel under the belly is left untreated, slightly coarse, but smoothed above the belly.

Showing signs of moderate secondary burning. Next to the handle, around the midline of the neck there is a trace of a blow that impacted the vessel from the outside. The vertical break-surface on the left, from the rim to the base was exposed to secondary heat (a large piece glued together from several fragments), but other fractures occurred after the secondary burning event, including the blow at the neck on the right of the handle.

Represents $40 \%$ of the vessel; Potter: Level 4; dR.: $33 \mathrm{~cm}$; tW.: 5-7 mm.

\section{Deep bowl (Fig. 32.1)}

The belly-line is in the upper third of the object. The vessel is strongly profiled including the shoulder. The rim is thickened slightly. Originally two handles rested on the shoulder and were attached to the 
rim from below. At the shoulder-belly joint, an upwardly protruding horizontally elongated, oval knob sits next to the handle. There were probably six such knobs on the object, two of them could have been perpendicular to the handles' axis, and another four close to the handles. Between the knobs and the handles, the shoulder is decorated with a row of short vertically positioned lines. The exterior surface is left untreated under the belly, with a slightly rough surface but it is smoothed above the belly.

Showing signs of severe secondary burning, distorted and blistered in a large area. $10 \mathrm{cms}$ of its vertical edge became vitrified, the walls swelled to two or three times of their original thickness. Other fractures occurred after secondary burning.

Represents $10 \%$ of the vessel; Potter: Level 3; dR.: $24.4 \mathrm{~cm}$; tW.: 5-8 mm.

\section{Large deep bowl (Fig. 32.2)}

Fragment of neck, rim and handle. The rim is slightly thickened and profiled. Originally, two handles rested on the shoulder and were attached to the rim from below.

dR.: $40 \mathrm{~cm}$; tW.: 8-10 mm.

\section{Storage vessel (Fig. 18.1, Fig. 41)}

Biconical body, the rounded belly is located in the midline of the body. The neck is funnelled, the rim is everted, thickened and profiled. At the shoulder-belly joint, a horizontal, $4 \mathrm{~mm}$ wide smoothed line can be found. Under the line, the surface is left untreated, slightly coarse, with traces of energetic curved smoothing left during the building process. Above the line the surface is smoothened and burnished. Directly below the line, a series of lenticular impressed dots were placed. Below the dots, incised triangular motifs with their tips pointing downwards from which vertical lines run towards the base. By looking at the patterns closely it becomes obvious that the right-hand side of the triangles were made by a shorter line with a shorter movement. The vertical lines (which form the left side of the triangle) were created by a single continuous motion. The upper third of the shoulder had four knobs, now all missing. Their broken surfaces were intentionally filed down, two of them were surely in an already abraded condition before the secondarily burning took place. The knobs are set at a 90 degree angle to each other, but with the handle the angle between the two closest knobs is 45 degrees. The knobs and the handle are connected together by five garland ornaments, which are made of three smoothed lines. On the shoulder below the knobs, a bundle of three short vertically incised lines hang, each finishing in an impressed lenticular dot. The shoulder-neck transition is emphasised by a smoothened horizontal edge. Below and alongside this edge, two horizontally smoothened lines can be seen. Below these lines, horizontally arranged, triple lenticular dots were placed between the knobs. However, a more sophisticated ornament is placed at the same height, opposite the handle. Here, a similar ornament is placed under the knobs, made from three smoothed, short, vertical lines each finishing in an impressed lenticular dot, with an additional two dots placed on each side of the meeting point of horizontal and vertical incised lines.

Shows signs of moderate secondary burning, the fractures occurring after the exposure to secondary heat. A rim/neck sherd has an imprint of a piece of grain embedded in its exterior, at the height of its centre line. $90 \%$ of the grain was pressed in to the vessel wall.

Represents $80 \%$ of the vessel; Potter: Level 4; dB.: $10 \mathrm{~cm}$; dR.: $24 \mathrm{~cm}$; H.: $37 \mathrm{~cm}$; tW.: 6-12 mm.

\section{Storage vessel (Fig. 19.2)}

The „identical twin” of Vessel 42. The only distinguishing detail is its slightly more angular body and the three horizontal lines that run under the profiled line on the neck. Unfortunately, due to most of the shoulder missing, the rich decoration can only be partially reconstructed. Only the end of the garland ornament, which runs from the base of the handle and the group of three horizontal, lenticular dots are preserved. The other decorations on the belly and below are exactly the same as on the previous vessel.

Shows signs of moderate secondary burning. The fractures occurred after the secondary burning event. Close to the base, imprints of the edge of a flat (smoothing) tool could be observed.

Represents $40 \%$ of the vessel; Potter: Level 4; dR.: $24 \mathrm{~cm}$; tW.: 5-10 mm. 


\section{Storage vessel (Fig. 26.4)}

On its elongated, ovoid body, the curved, flat belly is located in the upper third of the body. The shoulder meets the neck at a slight angle. The neck is slightly curved, almost cylindrical. The handle sits on the shoulder and joins the middle of the neck. The surface was smoothened only in the leather-dry stage, carelessly worked. Its wall thickness is quite thin considering the size of the object. Its handle is thick but at the top, from the side-view it appears thinner. The shape of the vessel is atypical.

Showing signs of moderate secondary burning. The neck is burnished, but the shine mostly rubbed off. Represents 70\% of the vessel; Potter: Level 3; dB.: $11.5 \mathrm{~cm}$; H(r).: $24.5 \mathrm{~cm}$; tW.: 4-8 mm.

\section{Small storage vessel (Fig. 18.2)}

Its belly is located at the lower third of the body. The shoulder-neck transition is profiled at a slight edge. The neck is funnelled. The rim is strongly thickened, profiled and everted. The handle rests on the shoulder and connects to the upper third of the neck. A horizontal band of combed decoration is placed on the shoulder-belly joint. From the lower edge of this band, the same combed decorations hang downwards, almost to the base of the vessel. Below the horizontal band, the surface is left untreated, slightly coarse, but smoothened and burnished above it. At the angle of the shoulder-neck joint, there are groups of three impressed lenticular dots arranged horizontally. One group of dots is opposite of the handle, one on each side of the perpendicular axis and one group is located next to the handle. Above the latter, a few centimetres higher the same design is repeated again.

Showing signs of severe secondary burning, distorted at several places. Underneath the belly, an oval area of $4 \times 5 \mathrm{~cm}$ peeled off (exploded) in a typical oval-shaped pattern, caused by thermal-shock on the exterior surface. The base of the vessel is cracked in a web-like pattern due to the secondariy exposure to heat. Some of the fractures, occurred during the secondary burning event, while others after. There is also a large chip on the edge of the rim, which was caused by a blow impacting it from a vertical direction. This typical use-wear damage occurred before the secondary burning event.

Represents 50\% of the vessel; Potter: Level 4; Fa.: 8.8 cm; dR.: 17 cm; H.: 25.8 cm; tW.: 2-10 mm.

\section{Storage vessel (Fig. 20.3)}

The belly located in the upper third of the elongated, ovoid body. The neck is funnelled. The rim is moderately everted. The handle rests on the upper part of the shoulder, and connects to the upper third of the neck. On the top of the shoulder, there are three round, middle-sized knobs, positioned in an angle of 90 degrees to each other and with the handle. At the transition between the belly and the shoulder, two horizontal incised lines are visible. Under these lines, the surface is left untreated, slightly rough, exhibiting traces of energetic movements of smoothing. Above the horizontal lines, the shoulder is smoothened and the neck is burnished vertically. Below the horizontal double line, the design is created by the combination of three lines. The lines in the centre are vertical, while the ones on the side are the sidelines of the ornaments form a 'V'-shape opening towards the base. The three lines join together and hang from the horizontal double lines.

Showing signs of slight secondary burning. The rim and the neck cracked vertically (in a length of 11 $\mathrm{cm}$ at two places, $5.5 \mathrm{~cm}$ apart from each other) due to the secondary heat exposure. These fracture surfaces were oxidized. Another part of the rim, there are two traces of very strong blows next to each other, which impacted the edge at a depth of $1.5 \mathrm{cms}$ and a width of $5 \mathrm{cms}$. Both blows came from a vertical direction from above. The patterns of these cracks suggest, that the tool causing the damage was flat and sharp. These damages occurred after the secondary burning event but before the deposition of the pot. Based on the photograph taken during the excavation, this object was one of the relatively intact pieces at the top of the pit.

Represents 90\% of the vessel; Potter: Level 4; dB.: 9.5 cm; dR.: 22 cm; H.: 42 cm; tW.: 6-10 mm.

\section{Storage vessel (Fig. 21.3)}

Biconical vessel, with pressed body. The belly is at the height of the midline of the body. The neck is funnelled. The rim is everted and thickens increasingly. The handle rests on the upper part of the shoul- 
der, and connects to the upper third of the neck. The neck and shoulder meet in a slight rib-like edge. At the shoulder-belly joint, there were four horizontally elongated, oval, large, flat knobs, but due to the fragmentation of the object, the only one that still remains is below the handle which was decorated with vertical, short lines. Another knob, applied 90 degrees from the previous, flaked off, a typical injury caused by thermal-shock. The knobs are connected horizontally with a double line. Under the lines, the surface is left untreated but relatively smooth. Above the double line, the shoulder, neck, rim, and the interior surface are well burnished. The lower part of the vessel is decorated with a web-like pattern.

Shows signs of slight secondary burning. Half of the neck and rim were broken before it came into contact with secondary heat. The vertical fracture surfaces of the remaining parts were oxidized. However, other fractures occurred after the secondarily burning event. Underneath the belly, the exterior surface broke off in oval-shaped patches at several areas, typically caused by thermal-shock. A chip on the edge of the rim could may be due to use, but another, above the handle certainly occured after the secondary heat exposure. At the height of the belly, a trace of a major blow can be detected, carried out by great force, resulting in a scale-like fracture pattern (with a diameter of $5 \mathrm{cms}$ ). The blow happened after the secondary burning event. A small vertically-sketched line visible under the broken knob, is a mark by the potter, to indicate the position of the knob before it was attached. Based on the photograph taken during the excavation, this object was one of the relatively complete pieces at the top of the pit.

Represents 40\% of the vessel; Potter: Level 5; dR.: 26 cm; tW.: 8-14 mm.

\section{Storage vessel (Fig. 22.3)}

Its belly is located on the upper third of the elongated body. The neck is funnelled. The rim is strongly everted, thickened and profiled. The interior surface of the rim is channelled right under the edge. On the upper part of the shoulder there are two triangular handles, their tips channelled creating an ansa lunata-like effect. The neck and shoulder join in a slight rib-like edge. At the shoulder-belly transition a horizontal, $4 \mathrm{~mm}$ wide, deep smoothed line can be found, which is strongly wavy at some places. The surface below the line is left untreated, but above it the vessel is burnished. The lower part of the vessel is decorated in a web-like pattern, which has been created by bundles of lines each containing three incised strands. The line bundles are similar to a combed ornament, but instead of a comb, the lines are made individually by a pointed implement.

Showing signs of moderate secondary burning. Most of the fractures occured after the secondary burning event.

Represents $40 \%$ of the vessel; Potter: Level 5; dR.: 25 cm; tW.: 6-10 mm.

\section{Storage vessel (Fig. 24.4)}

Slightly pressed, spherical vessel. The curved belly is located at the midline of the body. Neck is funnelled, the rim is slightly everted. Its handle and the upper part of the shoulder are missing. There is a horizontally incised line at the shoulder-belly transition. The surface below the line is left untreated, but smoothened above it. Underneath the line, there are open, baseless triangles, carelessly incised. The largest triangle is twice as big as the smallest, and the position of their angles are irregular. The decorator had a lower level of skill than the potter of the vessel.

Showing signs of moderate secondary burning. At the edge of the rim, it is chipped in three places. These damaged surfaces were later worn, but occurred prior to the secondary exposure to heat. The majority of other fractures were caused by the secondary burning event. Near to the base, an imprint of a piece of textile can be seen on the exterior surface in an area of $3 \times 3 \mathrm{cms}$ (Fig. 9.). The composition of the ceramic paste of the vessel differs from the other vessels of this assemblage.

Represents 30\% of the vessel; Potter: Level 4 (Level 2 for decoration); dB.: $11 \mathrm{~cm}$; dR.: $22.6 \mathrm{~cm}$; tW.: $7-10 \mathrm{~mm}$.

\section{Storage vessel (Fig. 23.2)}

The vessel has a slightly elongated, biconical body. Its rounded belly is located in the upper third of the body. There is a wide, deeply smoothened, horizontal line at the transition between the belly and the shoulder. The surface below the line is left untreated, but the vessel is burnished above it. Below 
the line, the vessel is decorated with vertical bundles of lines which are created by a six-toothed comb. Between the line bundles, under the horizontal line, the tip of the comb was pressed into the clay to create an ornament consisting of six dots.

Showing signs of slight-moderate secondary burning. Some of the fracture surfaces were exposed to secondary heat, but most of them occurred after the fire. Under the belly, a horizontal joint surface can be observed at a length of $4 \mathrm{cms}$, evidence for the slab-building technique.

Represents 20\% of the vessel; Potter: Level 4; dB.: $10.5 \mathrm{~cm}$; H(r):: $27.4 \mathrm{~cm}$; tW.: 7-13 mm.

\section{Storage vessel (Fig. 27.2)}

Belly-shoulder fragments of a biconical vessel with a slightly pressed body. At the transition between the belly and the shoulder, a horizontal, incised line is visible. The surface below this line is left untreated, but the vessel is burnished above it. Below the line, large ' $\mathrm{X}$ ' motifs are decorating the belly.

Showing signs of moderate secondary burning. The majority of fractures occurred after the secondary burning event. Under the belly, a horizontal joint surface can be observed.

Represents10\% of the vessel; Potter: Level 5; tW.: 7-10 mm.

\section{Storage vessel (Fig. 27.3)}

Belly-shoulder fragments of a biconical vessel. There is a large, round knob at the transition between the belly and the shoulder. Originally there could have been four of them, based on well-known parallels. The knobs are connected with a horizontal incised line. Below this line the surface is left untreated, but the vessel is burnished above it. Below the line is a web-like pattern, created by single lines.

Represents 5\% of the vessel; Potter: Level 4; tW.: 6-11 mm.

\section{Storage vessel (?) (Fig. 28.6)}

A large fragment either of a storage vessel's or a deep bowl's lower section. The external surface is decorated with a web-like pattern carried out by a three-toothed comb. Its interior surface is corroded in tiny dots, but the burnished surface is still visible.

tW.: $8 \mathrm{~mm}$.

\section{Storage vessel (Fig. 23.1)}

A shoulder-neck-rim fragment of a storage vessel. The neck is slightly funnelled and the rim thickened. The handle rests on the upper part of the shoulder and attached to the upper third part of the neck. At the shoulder-neck joint, a slight edge is created. At the height of the shoulder centerline, the shoulder's curve is unusually broken, decorated with a horizontal, line bundle created by a comb-like implement. On the shoulder, one of these combed bundles is running downwards. The wall and the handle of the object are uneven, irregular.

Showing signs of severe secondary burning, a bit distorted, its surface is crackled in a few places. The majority of fractures occurred after the secondary burning event.

Represents $10 \%$ of the vessel; Potter: Level 3; dR.: $22 \mathrm{~cm}$; tW.: 5-13 mm.

\section{Storage vessel (Fig. 25.1)}

A shoulder-neck-rim fragment of a storage vessel. The neck is slightly funnelled but almost cylindrical. The profiled rim is thickened. The handle rests on the upper part of the shoulder and attached to the upper third of the neck.

Shows signs of moderate secondary burning. At the centre of the neck, a horizontal joint surface is visible in a length of $4 \mathrm{cms}$. The wall thickness is uneven and the surface is irregular.

Represents 5\% of the vessel; Potter: Level 3; dR.: $18.5 \mathrm{~cm}$; tW.: 5-10 mm.

56. Storage vessel (Fig. 25.4)

A shoulder-neck-rim fragment of a storage vessel. The neck is funnelled, the rim is everted and slightly 
thickened. The upper part of the handle is attached to the upper third of the neck similar to the dowel-joint technique. At the shoulder-neck joint, a slight edge is created.

Showing signs of severe secondary burning. Above the handle, the edge of the rim is chipped in a $4 \mathrm{~cm}$ wide and $1.8 \mathrm{~cm}$ deep area in a scale-like pattern. The edges of this scar are rounded and worn prior to the secondary exposure to heat.

Represents $20 \%$ of the vessel; Potter: Level 4; dR.: $19 \mathrm{~cm}$; tW.: 7-10 mm.

\section{Storage vessel (Fig. 25.2)}

A shoulder-neck-rim fragment of a storage vessel. The neck is funnelled, the rim is everted and thickened. The handle rests on the upper part of the shoulder and attached to the centre of the neck. The shoulder and neck meet at a slight edge.

Showing signs of moderate secondary burning. The base of the handle and the break-surfaces around it are strongly rounded. These surfaces have also been oxidized, indicating intentional abrasion, prior to the secondary heat exposure (Fig. 7.b).

Represents 10\% of the vessel; Potter: Level 4; dR.: $26 \mathrm{~cm}$; tW.: $8-12 \mathrm{~mm}$.

\section{Storage vessel (Fig. 26.1)}

A shoulder-neck-rim fragment of a storage vessel with two handles. The neck is funnelled, the rim is strongly everted and thickened. The handles rest on the upper part of the shoulder and attached to the centre of the neck. The shoulder-neck joint is profiled with a slight edge. The profiled edge is accompanied by two distinctly incised lines from below, under these, a row of dots are visible, carried out by a vertically pressed tip of a blunt tool.

Showing signs of moderate secondary burning. The fracture surfaces on the right of the intact handle are strongly abraded in a length of $5 \mathrm{cms}$ into a spherical shape. These surfaces have also been oxidized, i.e., they were worn before the exposure to secondary heat. The fracture surfaces of the triangular scars on the rim were formed after the secondary burning event.

Represents $10 \%$ of the vessel; Potter: Level 3; dR.: $26 \mathrm{~cm}$; tW.: 6-10 mm.

\section{Storage vessel (Fig. 26.3)}

Neck-rim fragment of a storage vessel. The neck is slightly funnelled, the rim is slightly everted. Represents 5\% of the vessel; Potter: Level 4; dR.: $18.4 \mathrm{~cm}$; tW.: 5-7 mm.

\section{Storage vessel (Fig. 25.3)}

Shoulder-neck fragment of a storage vessel with handle. The neck is funnel-shaped. The handle rests on the upper part of the shoulder and attached to the upper third of the neck. At the shoulder-neck joint, the surface is profiled creating a strong edge. In the middle of the hourglass-shaped handle runs a slight edge, making it appear in cross-section as a triangle with rounded corners.

Its internal surface is slightly eroded. It probably represents the previous chronological phase than the rest of the assemblage.

tW.: 4-9 mm.

\section{Storage vessel (Fig. 28.1)}

Shoulder and neck fragment. The shoulder and neck joint at a strong edge. On the shoulder, there are garland ornaments, which are created by three smoothed line bundles. The ornaments are not entirely regular. One garland has a smaller curve than the others and the adjacent garland does not meet at the peak, but joins at its side. Probably this part represents the area right next to the handle. Above the peaks of the garlands, there were three large impressed lenticular dots, arranged horizontally, just below the profiled edge. There are a group of a further three impressed lenticular dots arranged horizontally below and above the lowest part of the garlands' curves (in one case four such dots form a group). Below the meeting point of the garlands vertically smoothed three short bundles of lines were placed, finishing in a horizontally arranged, group of three lenticular dots. 
Showing signs of moderate secondary burning. The majority of fractures occurred during or before the secondary burning event, but two breakages happened after the exposure to secondary heat.

Represents $10 \%$ of the vessel; Potter: Level 3; tW.: 6-9 mm.

62. Storage vessel (Fig. 28.3)

A shoulder fragment of a storage vessel, with two pieces of garland ornaments created by three smoothened lines. Below the point where the two garland meet, horizontally arranged, three impressed lenticular dots are placed.

Shows signs of severe secondary burning. It became strongly blistered at one part of the surface.

tW.: 6-7 mm.

\section{Storage vessel (Fig. 28.2)}

A shoulder fragment of a storage vessel. The shoulder and neck join in a sharply profiled edge. Immediately below that line, there are two large impressed lenticular dots (there were originally probably three).

Showing signs of moderate secondary burning. The fractures of the lower part occurred after the secondary burning event. The upper, horizontal fracture surface is slightly worn, and burnt secondarily.

tW.: 6-8 mm.

\section{Storage vessel (Fig. 27.1)}

A neck-rim fragment of a storage vessel. The neck is funnel-shaped, the rim is strongly everted and strongly thickened, with a rounded profile.

Showing signs of severe secondary burning. The fragment began to melt and it is vitrified in one place. The left vertical break-surface occurred after the secondary burning event while the right vertical breakage happened before or during the exposure to secondary heat.

Represents 5\% of the vessel; Potter: Level 5; dR.: $28 \mathrm{~cm}$; tW.: 7-10 mm.

\section{Storage vessel (Fig. 26.2)}

A rim fragment of a storage vessel. The neck is funnel-shaped, the rim is strongly everted, slightly thickened and profiled.

dR.: $23 \mathrm{~cm}$; tW.: 7-10 mm.

\section{Storage vessel (Fig. 28.5)}

A shoulder fragment of a storage vessel. On the transition between the belly and the shoulder, a rib runs horizontally, its top side flattened, decorated with dense lenticular dots.

Showing signs of serere secondary burning. Two fracture surfaces occurred before, two after the exposure to secondary heat.

tW.: 8-9 mm.

\section{Storage vessel (Fig. 32.4)}

Fragment of belly and shoulder of a storage vessel. At the transition between the belly and the shoulder, a wide, smoothed line runs horizontally. Below this line, the surface is left untreated, but the vessel is smoothened above it. Below the line there are traces of a decoration carried out by a three-toothed comb.

Slightly secondarily burnt in small patches. The sherd was already in this fragmented state when it came in contact with the fire. Its internal surface is strongly eroded and strongly worn. It represents an earlier phase than the rest of the assemblage.

tW.: $8 \mathrm{~mm}$. 


\section{Storage vessel (Fig. 33.2)}

A belly fragment of a storage vessel. A little bit above the widest circumference of the belly, is horizontal rib decorated with finger-impressions.

tW.: $10-11 \mathrm{~mm}$.

\section{Storage vessel (Fig. 34.2)}

A belly fragment of a storage vessel. A little bit above the widest circumference of the belly, is horizontal rib decorated with finger-impressions.

tW.: 11-12 mm.

\section{Storage vessel (Fig. 36.1)}

Large biconical storage vessel. The belly is strongly profiled and its midline located at the upper part of the body. The funnel-shaped neck is wide and short. The rim is slightly thickened, everted and profiled. At the shoulder-neck joint, a wide, deeply smoothened line emphasize this angle. Slightly above the belly, a rib runs horizontally, densely decorated with diagonal impressions created by an edge of a tool. The surface under the rib is left untreated, but the vessel is smoothened and burnished above it. Considering the size of the object, the wall is surprisingly thin. The unique design features, proportions and the wall thickness may indicate the ceramic tradition of Transdanubian Encrusted Pottery Culture.

Fragments of the lower part show signs of severe secondary burning, sherds are distorted and blistered on their surface (Fig.13.d). Shoulder-to-neck sherds showed traces of moderate secondary burning. The vessel broke before or during the exposure to secondary heat but most of the breakages occurred afterwards. There are eight chips at the edge of the existing rim, all of which occurred before the secondary burning event (Fig. 7.c). Some of the chips were relatively old, with rounded corners (Fig. 7.c, on the right), but some of them occurred relatively closer in time to the secondary burning event (Fig. 7.c, on the left).

Represents $10 \%$ of the vessel; Potter: Level 5; dR.: $46 \mathrm{~cm}$; tW.: 5-8 mm.

\section{Fermenting vessel (?) (Fig. 28.4)}

Fragment of a shoulder. On the upper part of the shoulder has a large flattened rib running horizontally, with dual or triangular, tool-impressed decorations. There are curved bundles of lines created by a comb-like implement under the rib. Although the sherd has no clear attributes, such as a hole on the shoulder, it is most likely belongs to the class of fermenting vessels, based on our observation. According to our experience, large ribs on the top of the shoulder and combed decorations on the shoulder occurring together are typical characteristics of fermenting vessels and only a few other exceptions are known.

Shows signs of moderate secondary burning. All break-surfaces occurred after the exposure to secondary heat. tW.: 8-10 mm.

\section{Fermenting vessel (Fig. 38.1)}

Slightly pressed, spherical vessel with a rounded belly with a midline at the centre of the body. The neck is funnel-shaped, the rim is strongly thickened. The inner side of the rim has a convex profiled part. Robust handles rest on the upper part of the shoulder and connect to the centre of the neck. (Even though only one handle of the object remained, the well-known examples of this type all have two handles.) At the transition between the belly and the shoulder, a rib runs horizontally, decorated with finger-impressions. Under the rib, the surface is left untreated, but the vessel is smoothened above it. At the shoulder-neck joint, an other rib runs horizontally, also decorated with finger-impressions and connecting to the bases of the handles. Underneath the handles and perpendicular to their axes, mustache-shaped ornaments were formed by finger-impressed plastic ribs. Immediately below the ornament the wall is perforated with a hole $(1 \mathrm{~cm}$ in diameter). Below the mustache-ornaments three bundles of lines (consisting of three thin, finely combed lines) hang in a triangular form. The bundle 
in the middle is straight, vertical, while the two lateral, are curved and slightly diagonal. The belly is decorated with vertical line bundles, which are also made with a comb, but not with the same tool as the one used on the shoulder. There are several large, round, pointed knobs on the interior of the base. Based on the existing fragments, there were at least four knobs originally. The pattern of their arrangement is unknown because only one of them fitted together with other fragments. The base of the vessel is missing, but it was most likely rounded, given the well known examples.

Showing signs of severe secondary burning, its surface cracked in a web-like pattern at several places. Above the handle, a $14 \mathrm{~cm}$ wide, $6 \mathrm{~cm}$ long fragment broke out of the rim. This occurred before the vessel came into contact with secondary heat as the break-surface is fully oxidized. Some fractures occurred during the secondary burning event, with slightly oxidized break-surfaces. However, most of the fractures occurred after the exposure to secondary heat, they are not oxidized at all. On the outside of the neck, below its centreline, on the right of the handle, an impression of a grain is visible (about $90 \%$ of the grain was pressed into the clay), while there is another grain-impression located somewhere below the belly.

Represents $40 \%$ of the vessel; Potter: Level 5; dR.: 29 cm, tW.: 8-17 mm. 

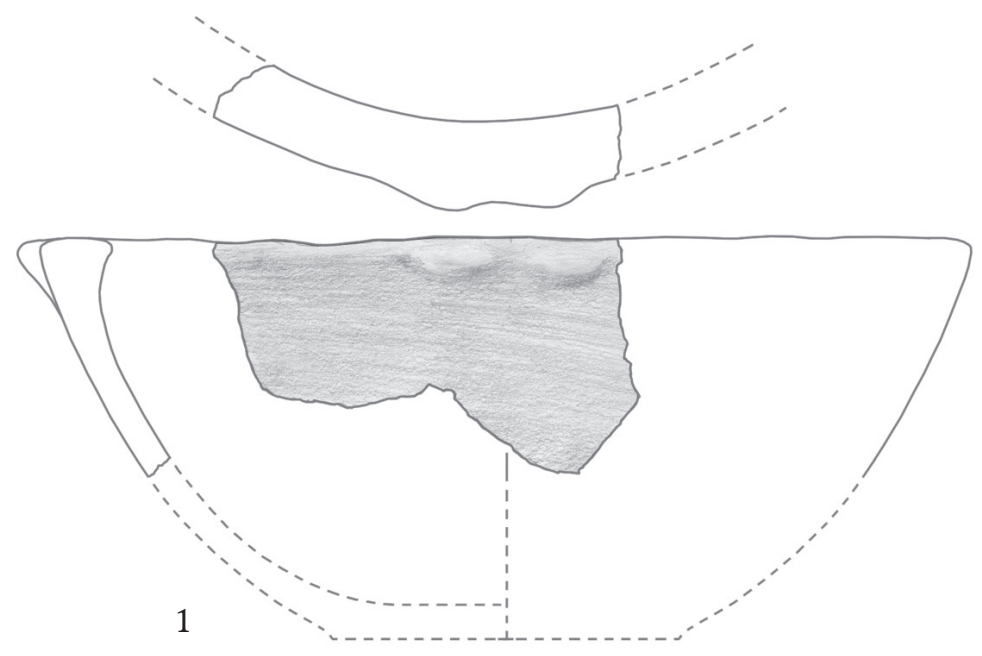

2

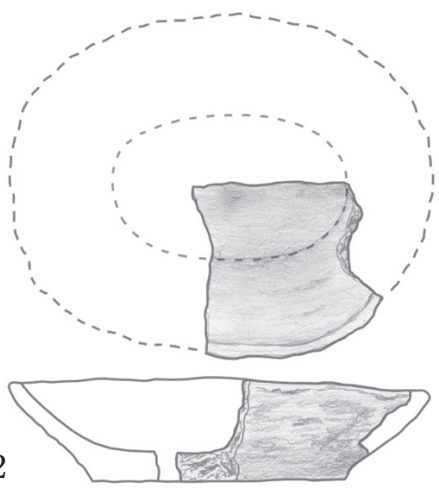

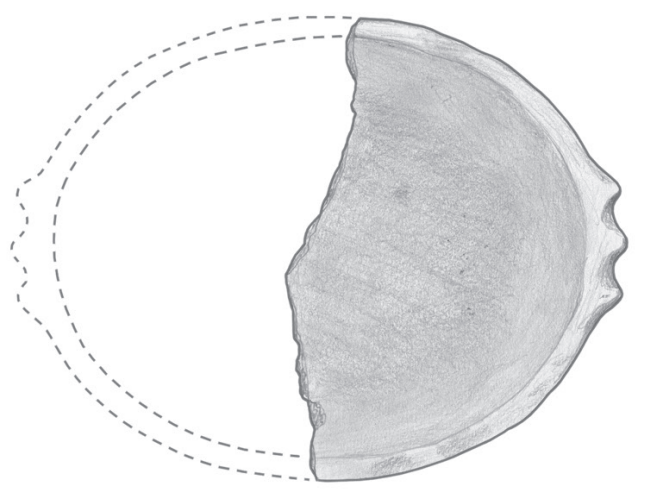
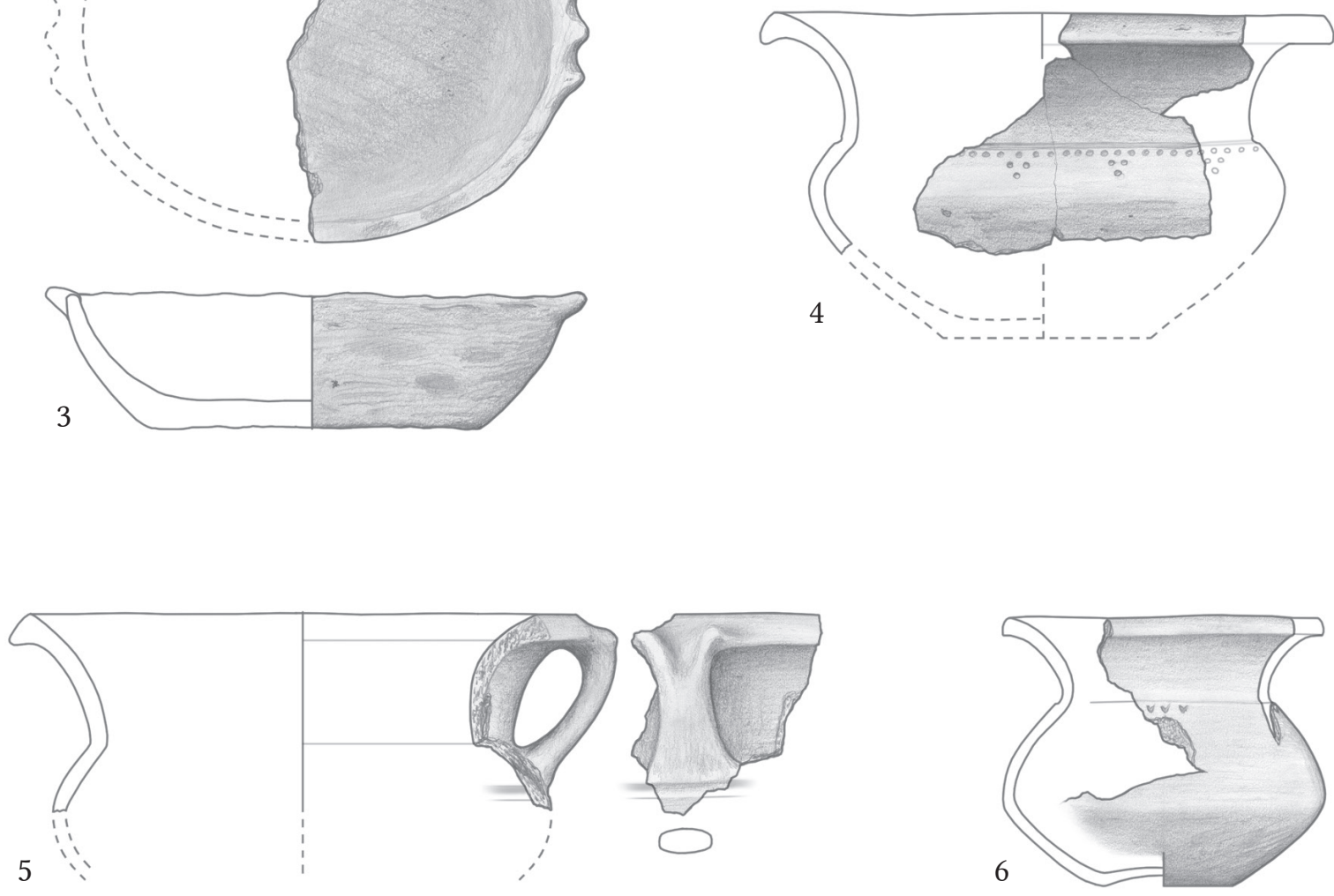

$10 \mathrm{~cm}$

Fig. 17. Vessels from Feature 80. 1 - Vessel 20, 2 - Vessel 21, 3 - Vessel 19, 4 - Vessel 17, 5 - Vessel 18, 6 - Vessel 4 (Drawings: László Gucsi). 


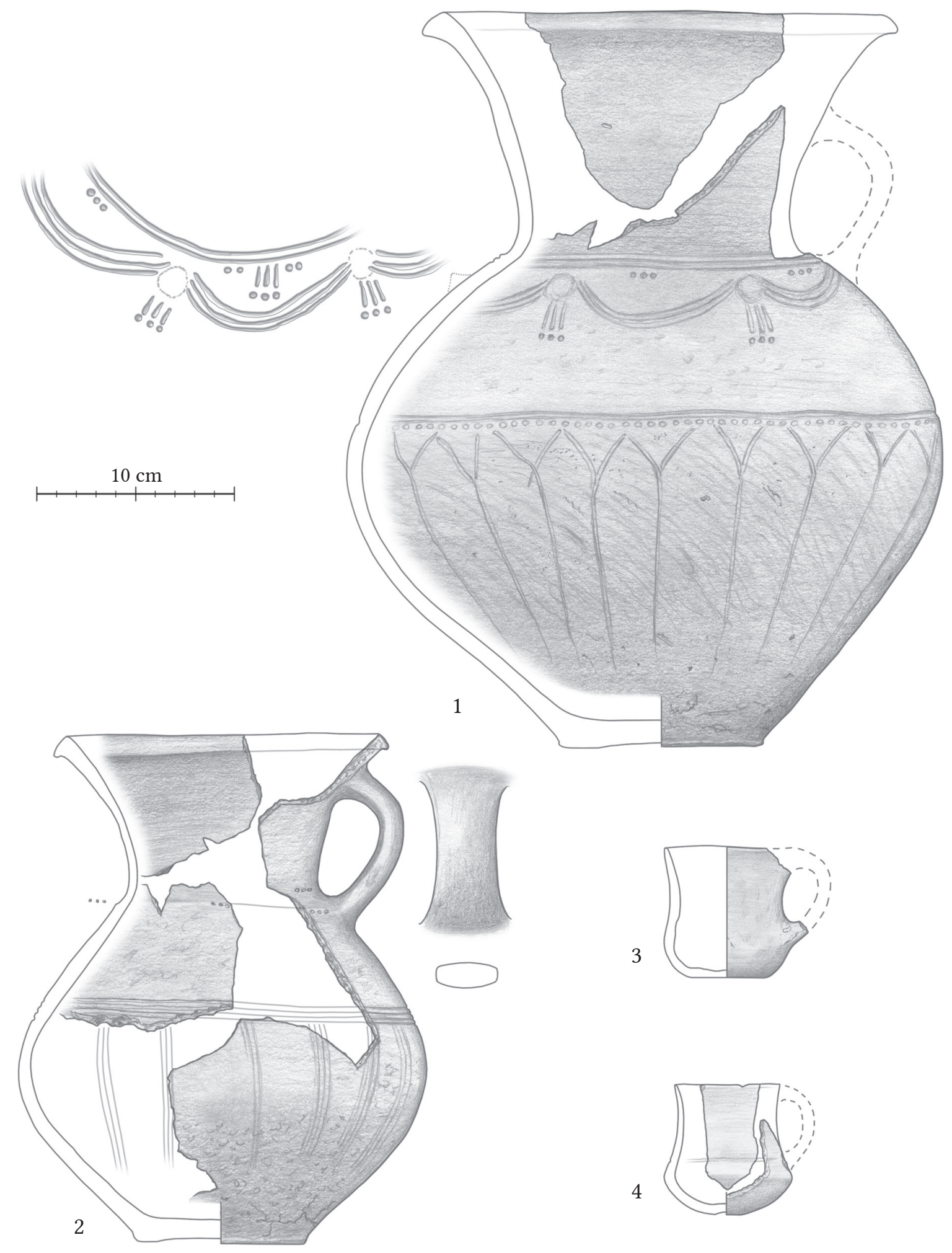

Fig. 18. Vessels from Feature 80. 1 - Vessel 42, 2 - Vessel 45, 3 - Vessel 1, 4 - Vessel 2 (Drawings: László Gucsi). 


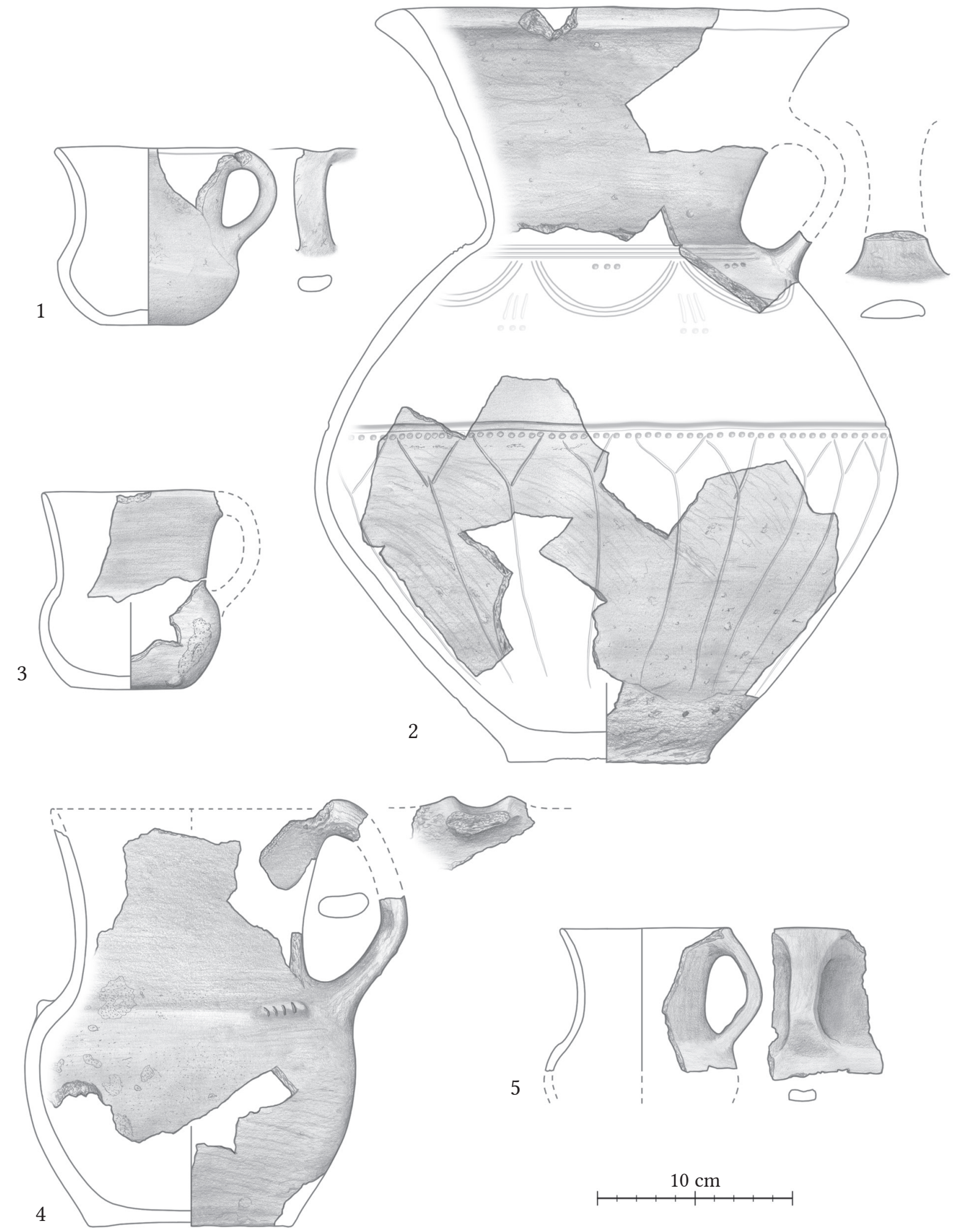

Fig. 19. Vessels from Feature 80. 1 - Vessel 3, 2 - Vessel 43, 3 - Vessel 12, 4 - Vessel 16, 5 - Vessel 10 (Drawings: László Gucsi). 

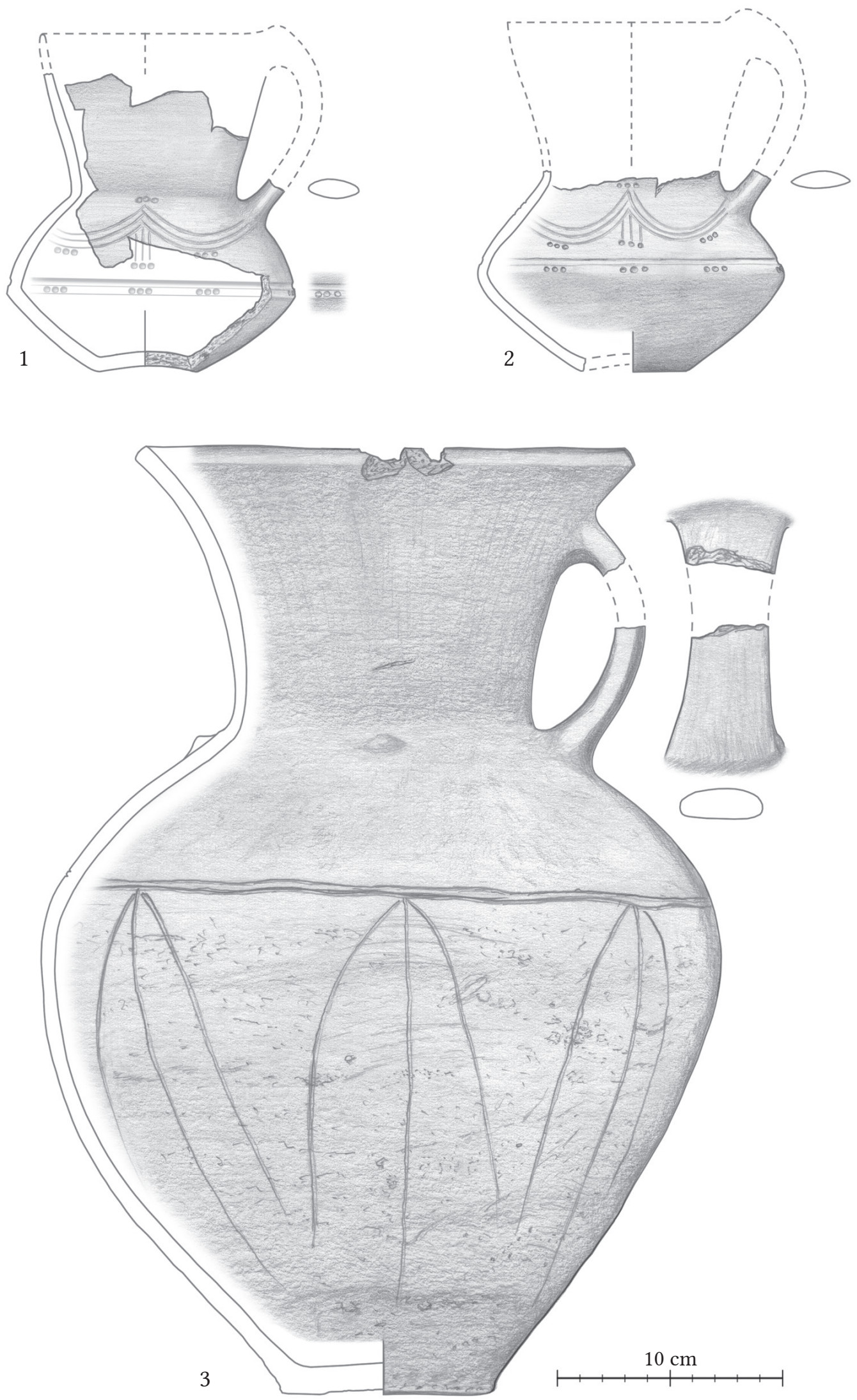

Fig. 20. Vessels from Feature 80. 1 - Vessel 5, 2 - Vessel 6, 3 - Vessel 46 (Drawings: László Gucsi). 
1

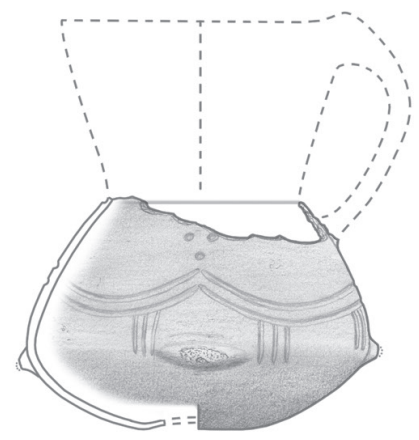

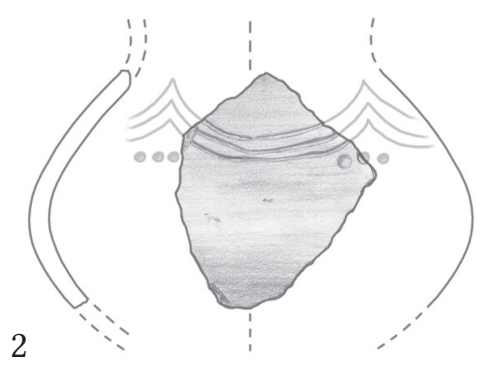

2

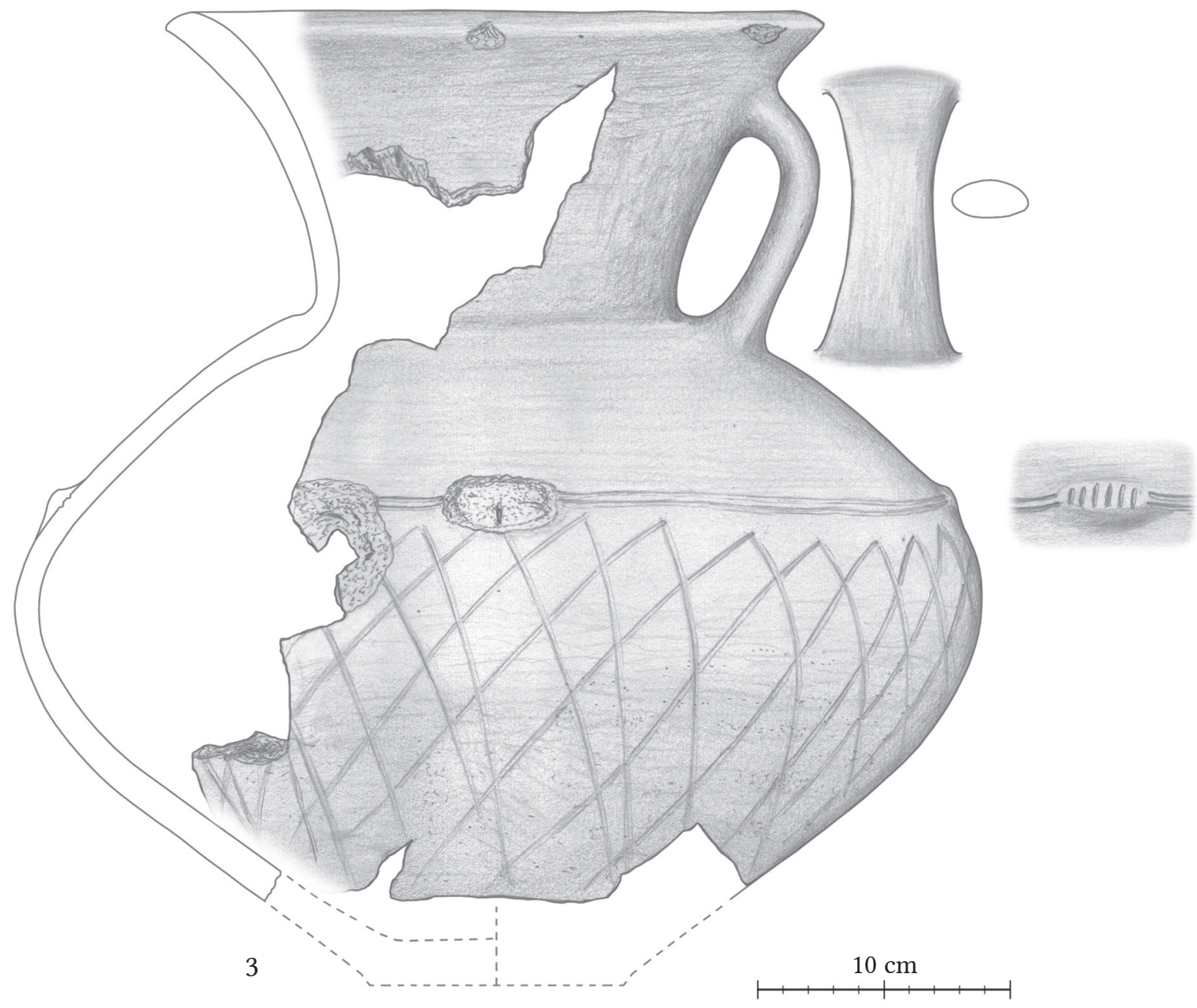

Fig. 21. Vessels from Feature 80. 1 - Vessel 7, 2 - Vessel 11, 3 - Vessel 47 (Drawings: László Gucsi). 

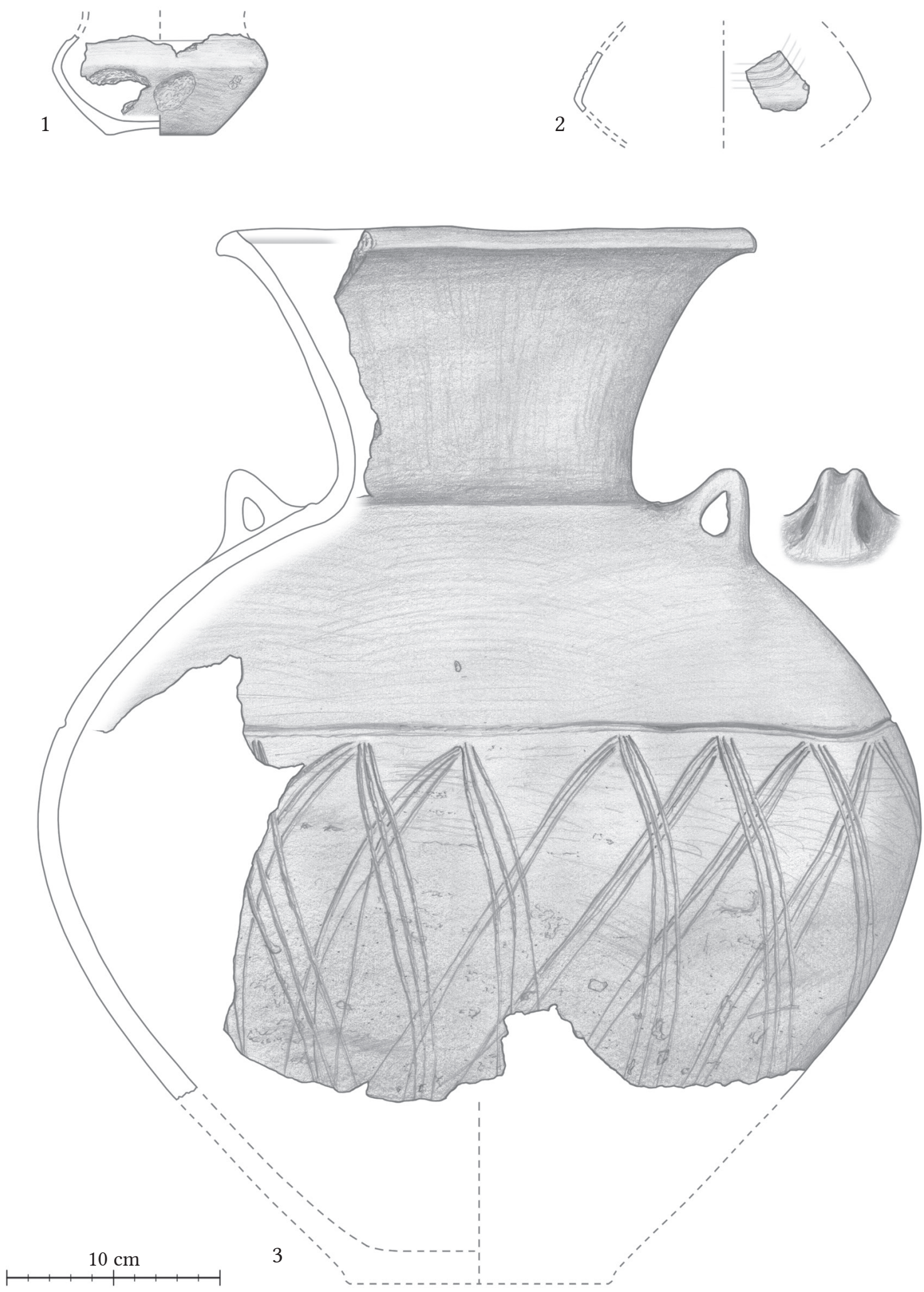

Fig. 22. Vessels from Feature 80. 1 - Vessel 8, 2 - Vessel 9, 3 - Vessel 48 (Drawings: László Gucsi). 

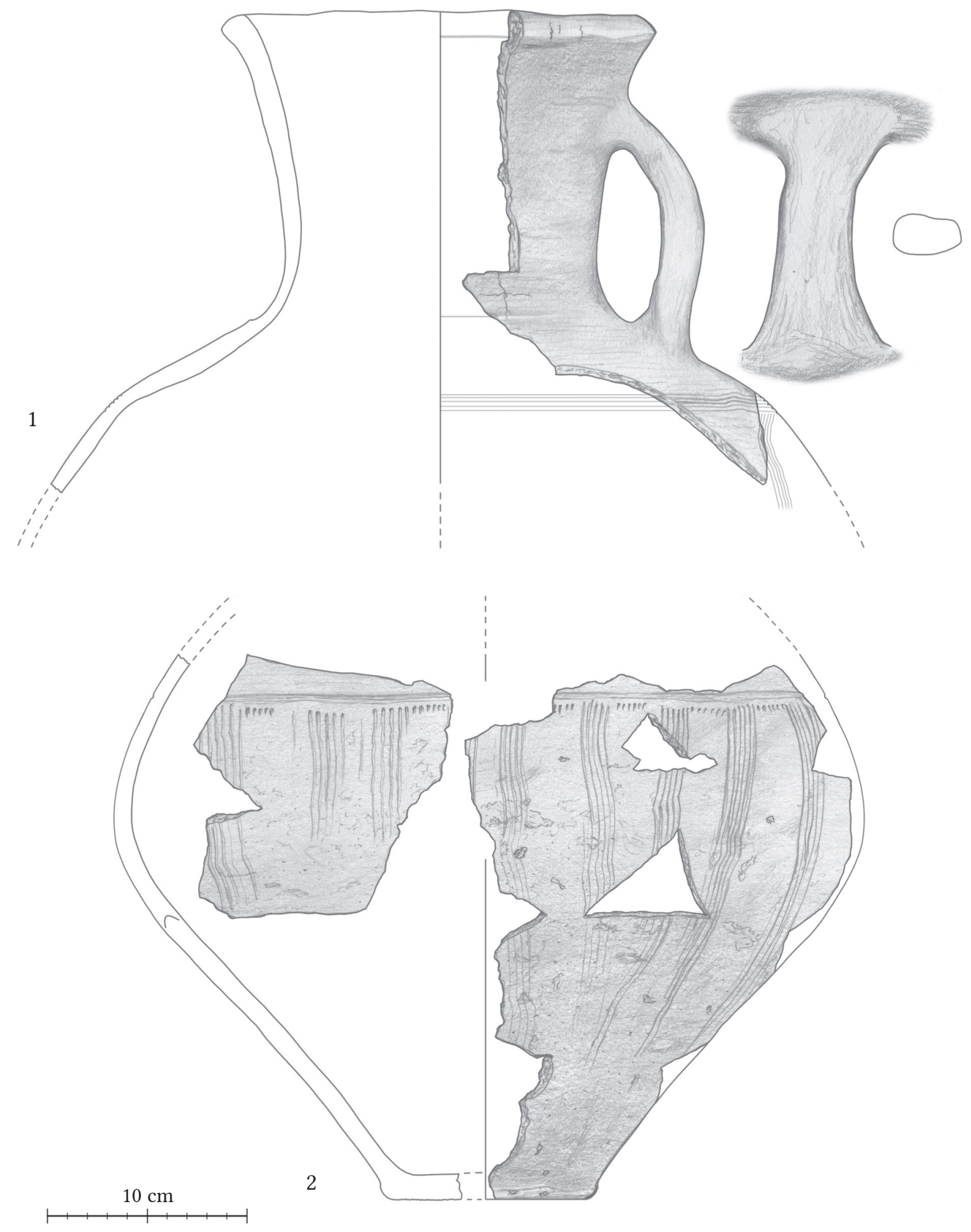

Fig. 23. Vessels from Feature 80. 1 - Vessel 54, 2 - Vessel 50 (Drawings: László Gucsi). 


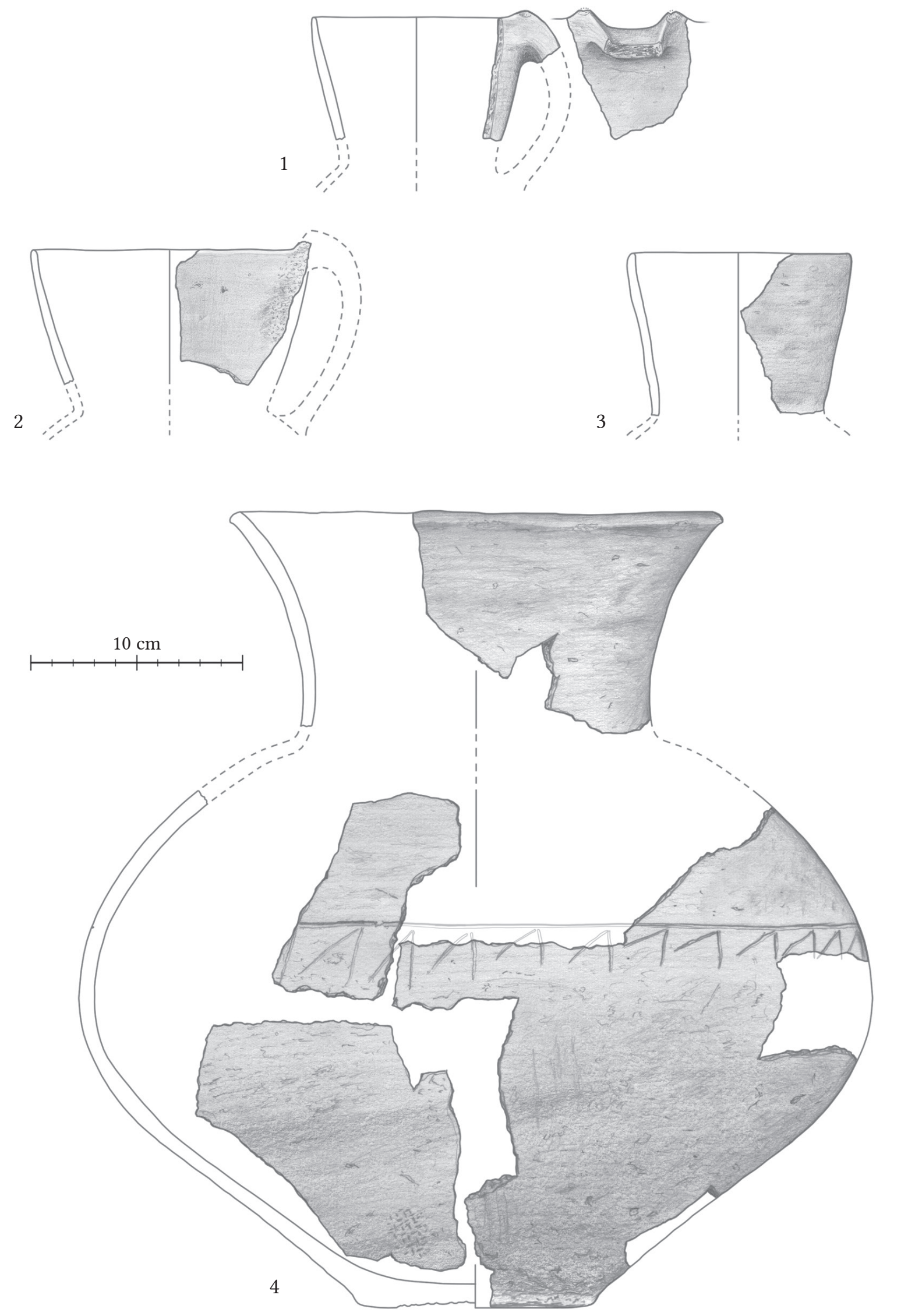

Fig. 24. Vessels from Feature 80. 1 - Vessel 15, 2 - Vessel 14, 3 - Vessel 13, 4 - Vessel 49 (Drawings: László Gucsi). 

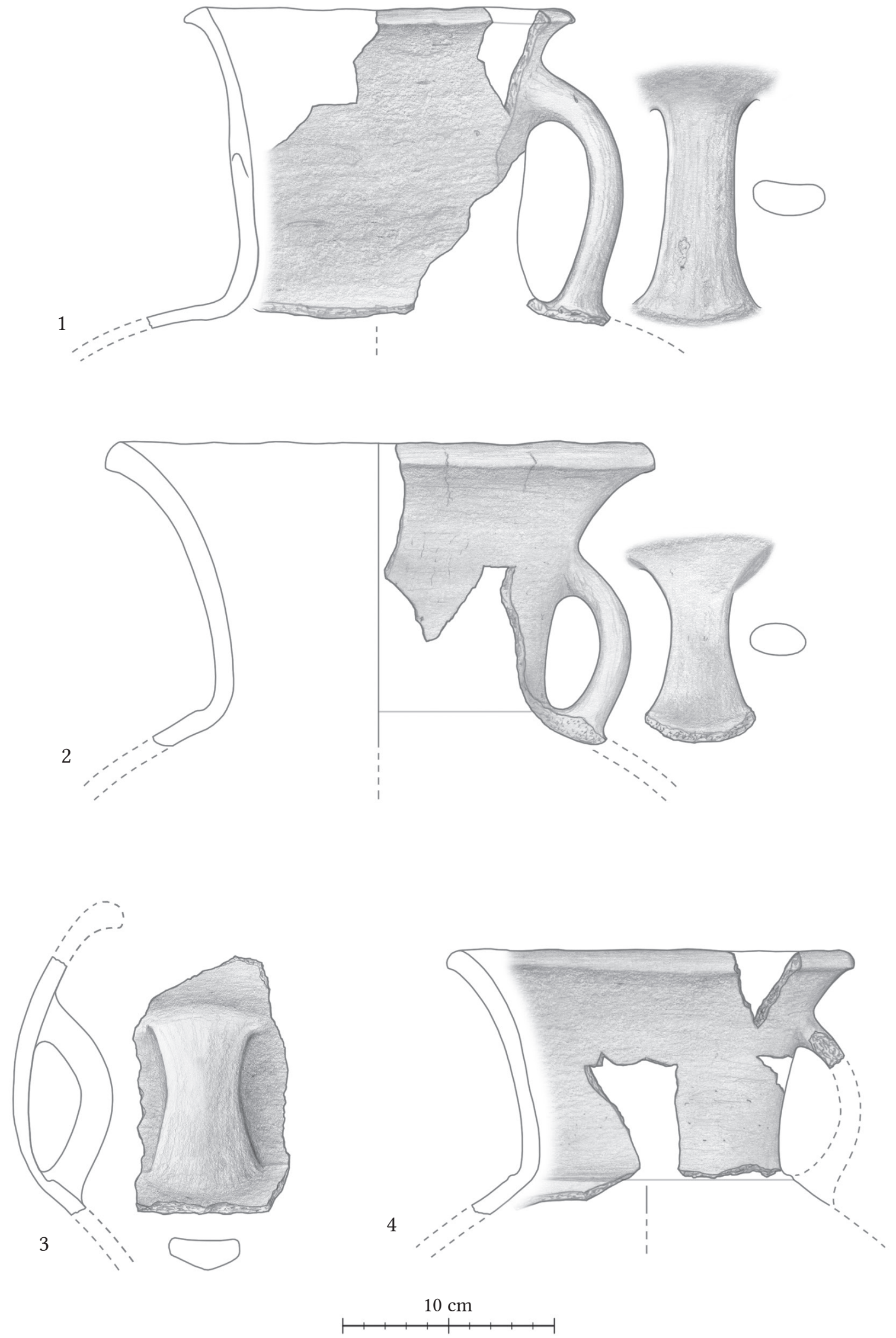

Fig. 25. Vessels from Feature 80. 1 - Vessel 55, 2 - Vessel 57, 3 - Vessel 60, 4 - Vessel 56 (Drawings: László Gucsi). 

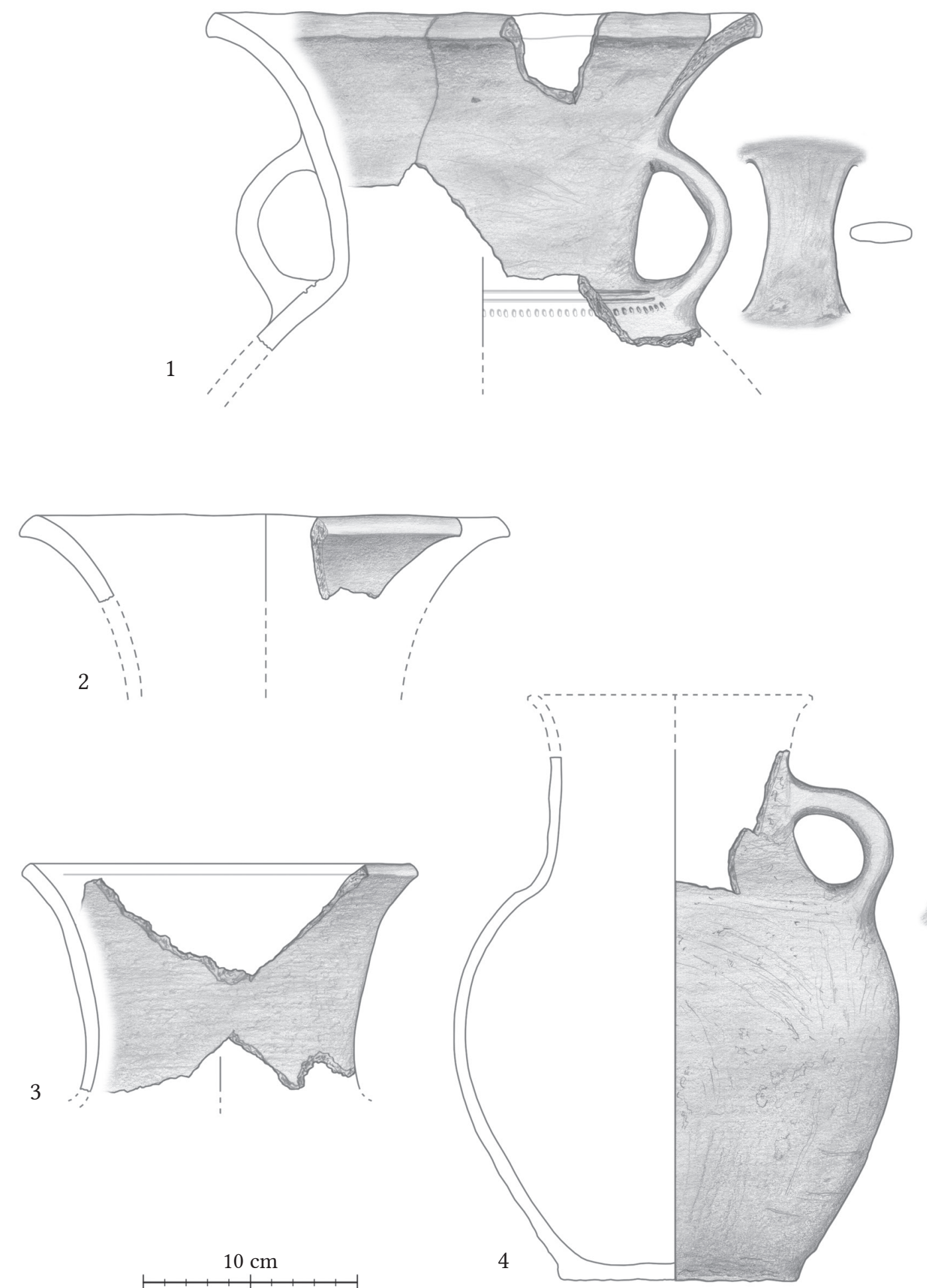

Fig. 26. Vessels from Feature 80. 1 - Vessel 58, 2 - Vessel 65, 3 - Vessel 59, 4 - Vessel 44 (Drawings: László Gucsi). 

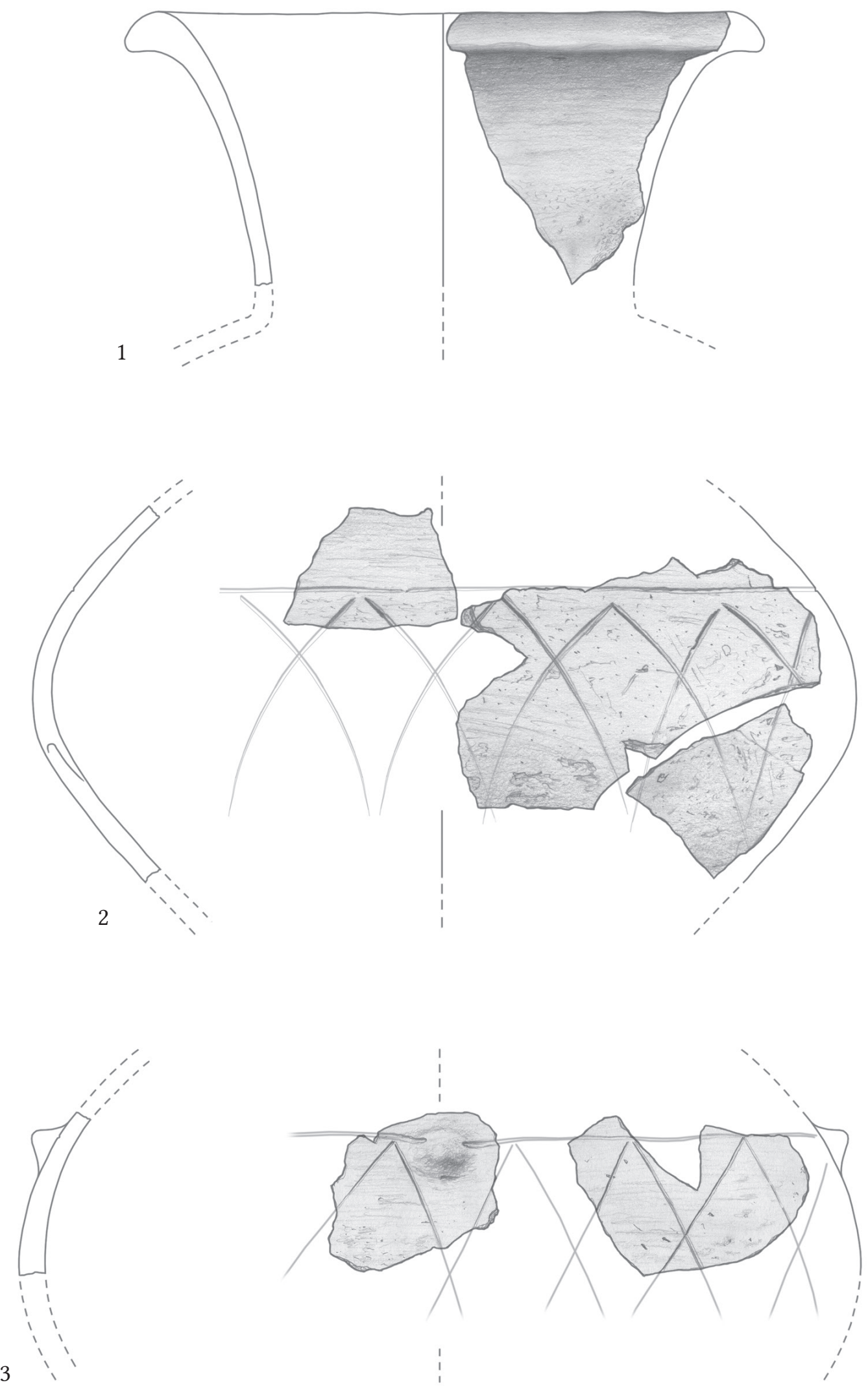

$10 \mathrm{~cm}$

Fig. 27. Vessels from Feature 80. 1 - Vessel 64, 2 - Vessel 51, 3 - Vessel 52 (Drawings: László Gucsi). 

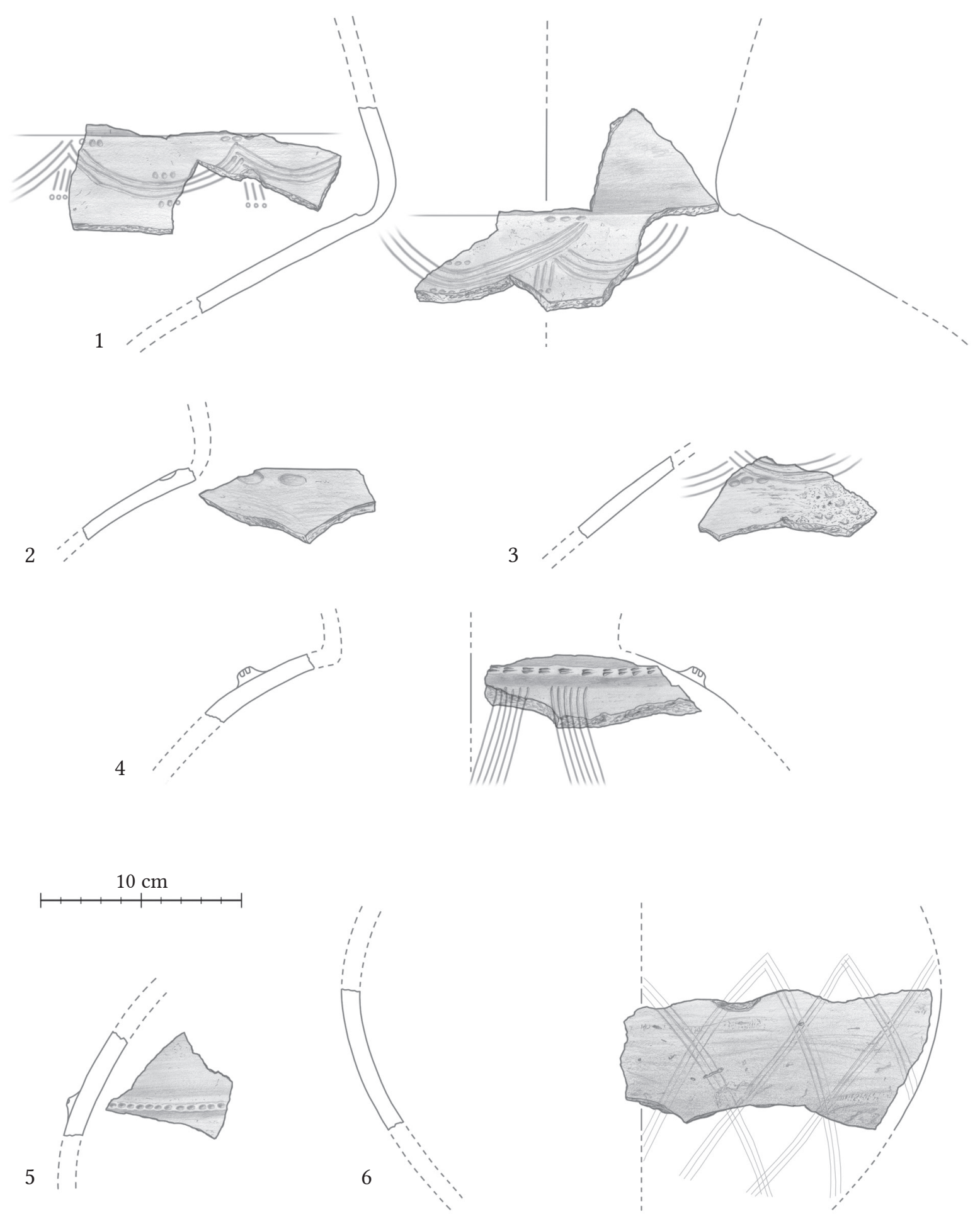

Fig. 28. Vessels from Feature 80. 1 - Vessel 61, 2 - Vessel 63, 3 - Vessel 62, 4 - Vessel 71, 5 - Vessel 66, 6 - Vessel 53 (Drawings: László Gucsi). 

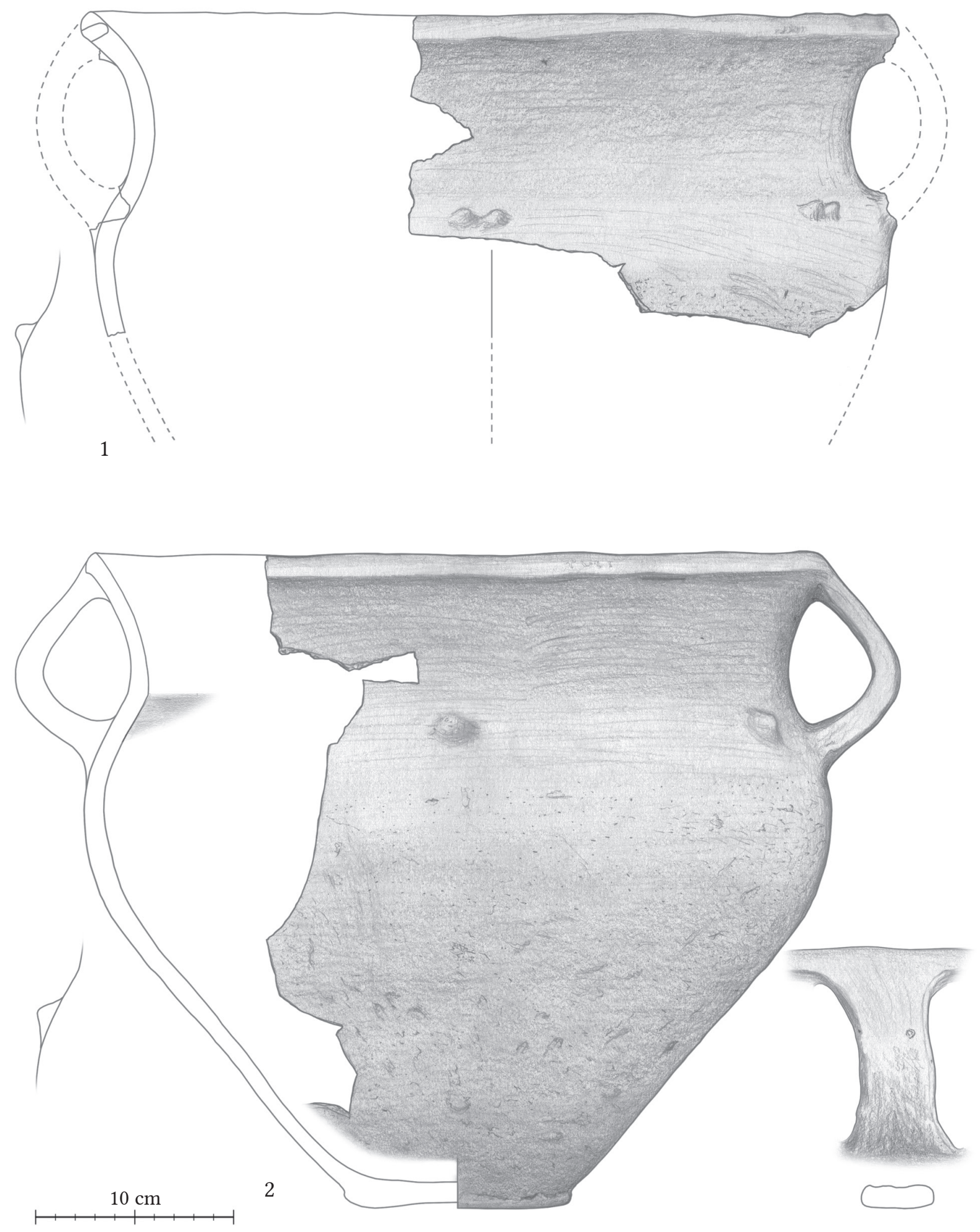

Fig. 29. Vessels from Feature 80. 1 - Vessel 34, 2 - Vessel 33 (Drawings: László Gucsi). 

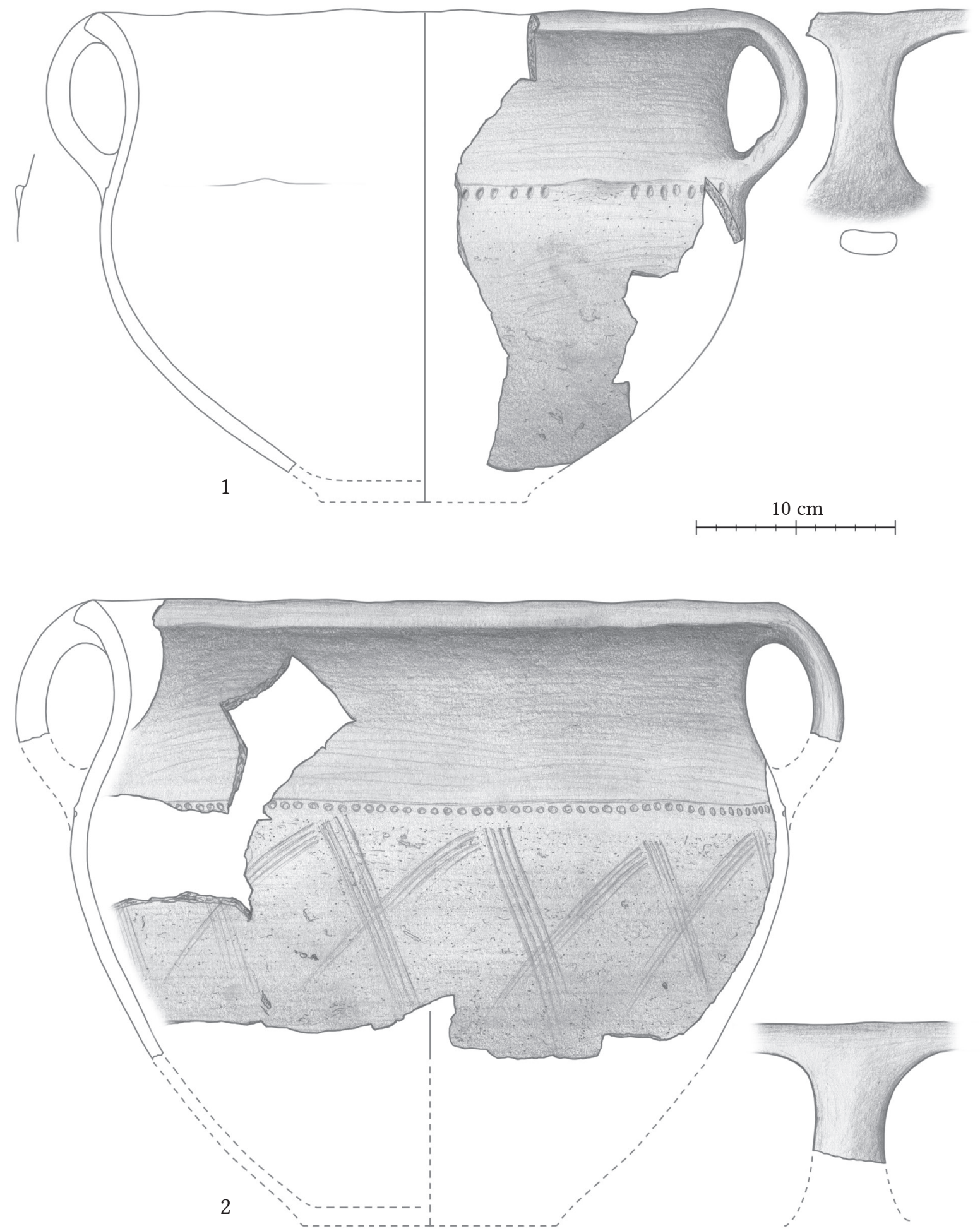

Fig. 30. Vessels from Feature 80. 1 - Vessel 39, 2 - Vessel 35 (Drawings: László Gucsi). 

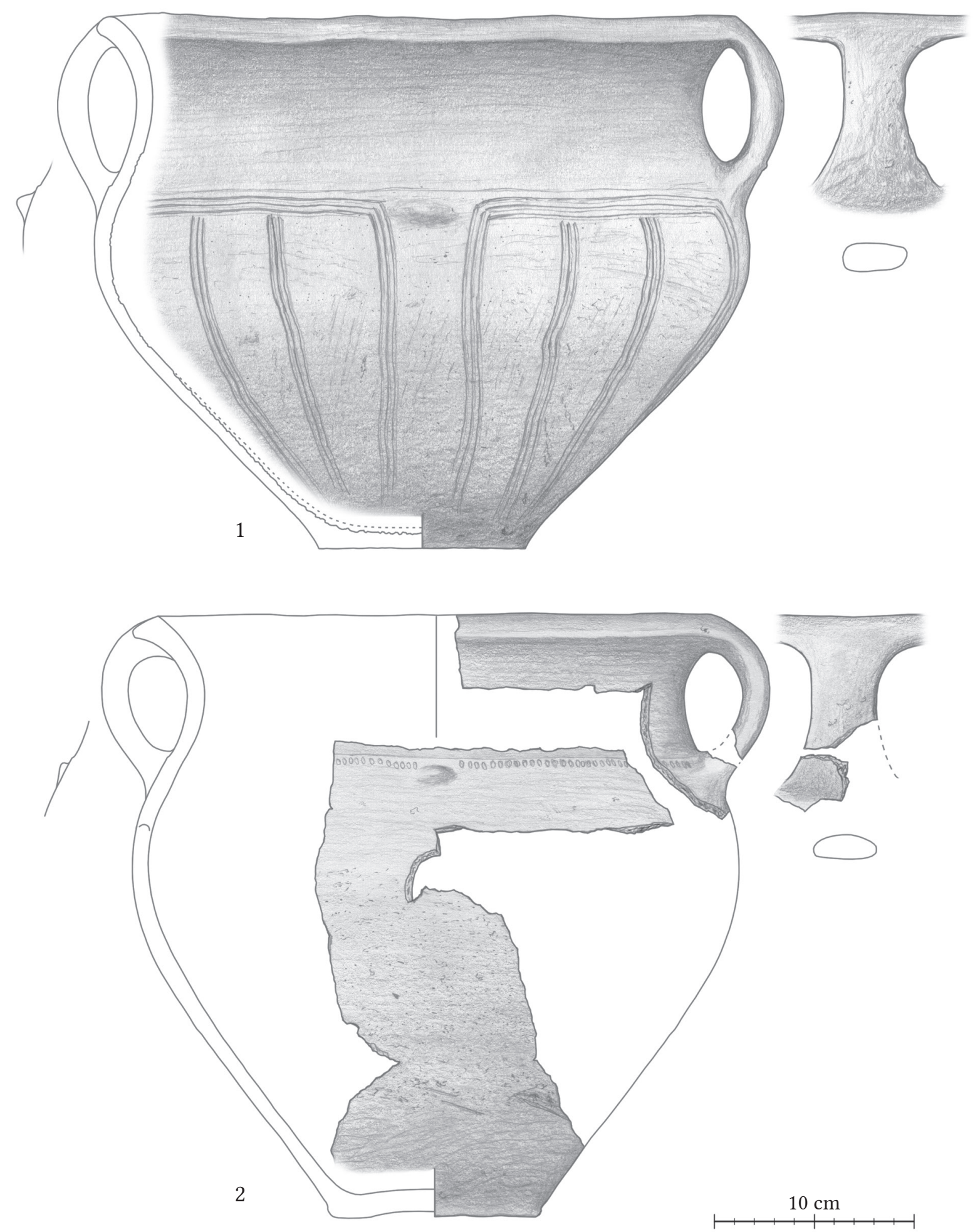

Fig. 31. Vessels from Feature 80. 1 - Vessel 36, 2 - Vessel 37 (Drawings: László Gucsi). 

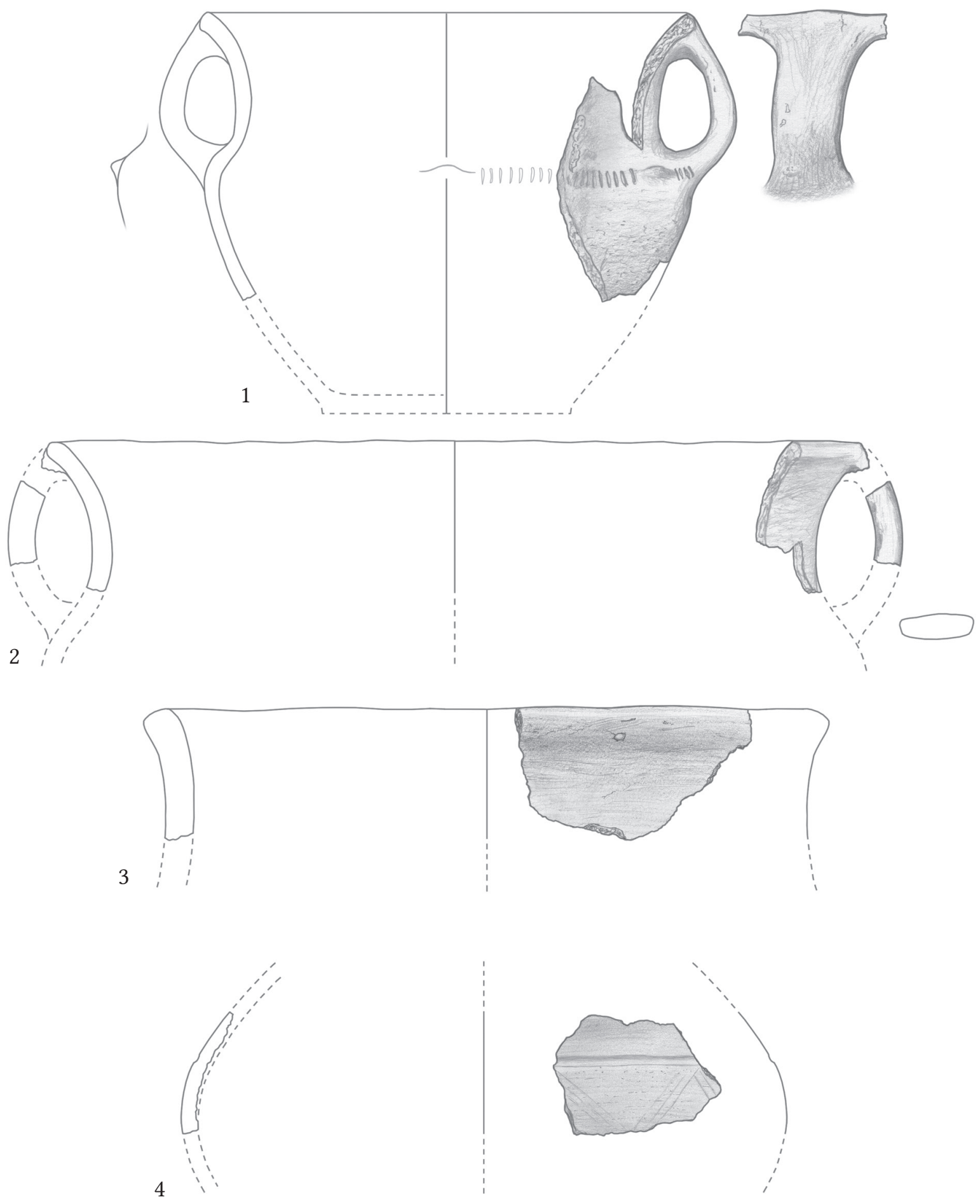

$10 \mathrm{~cm}$

Fig. 32. Vessels from Feature 80. 1 - Vessel 40, 2 - Vessel 41, 3 - Vessel 29, 4 - Vessel 67 (Drawings: László Gucsi). 

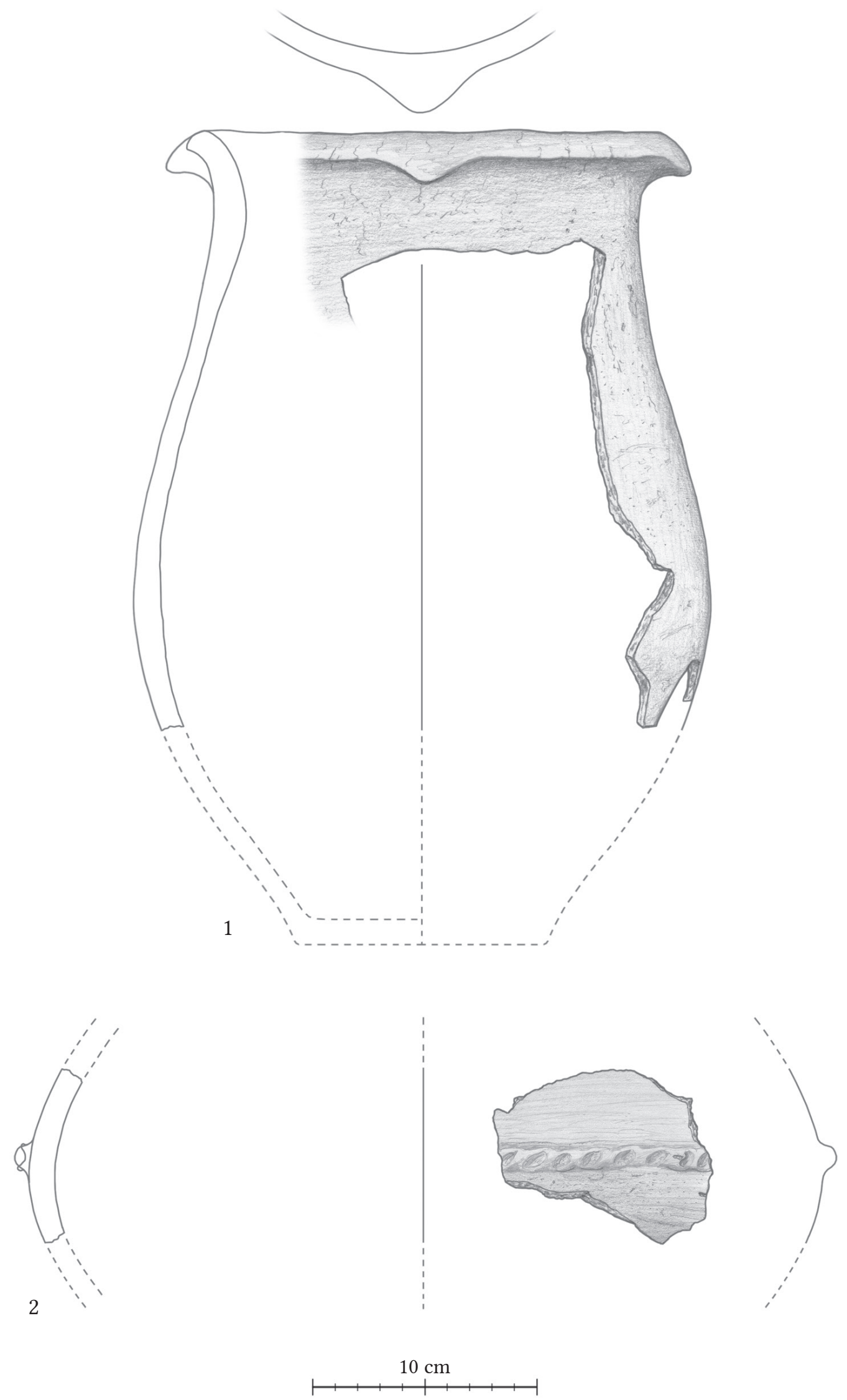

Fig. 33. Vessels from Feature 80. 1 - Vessel 24, 2 - Vessel 68 (Drawings: László Gucsi). 

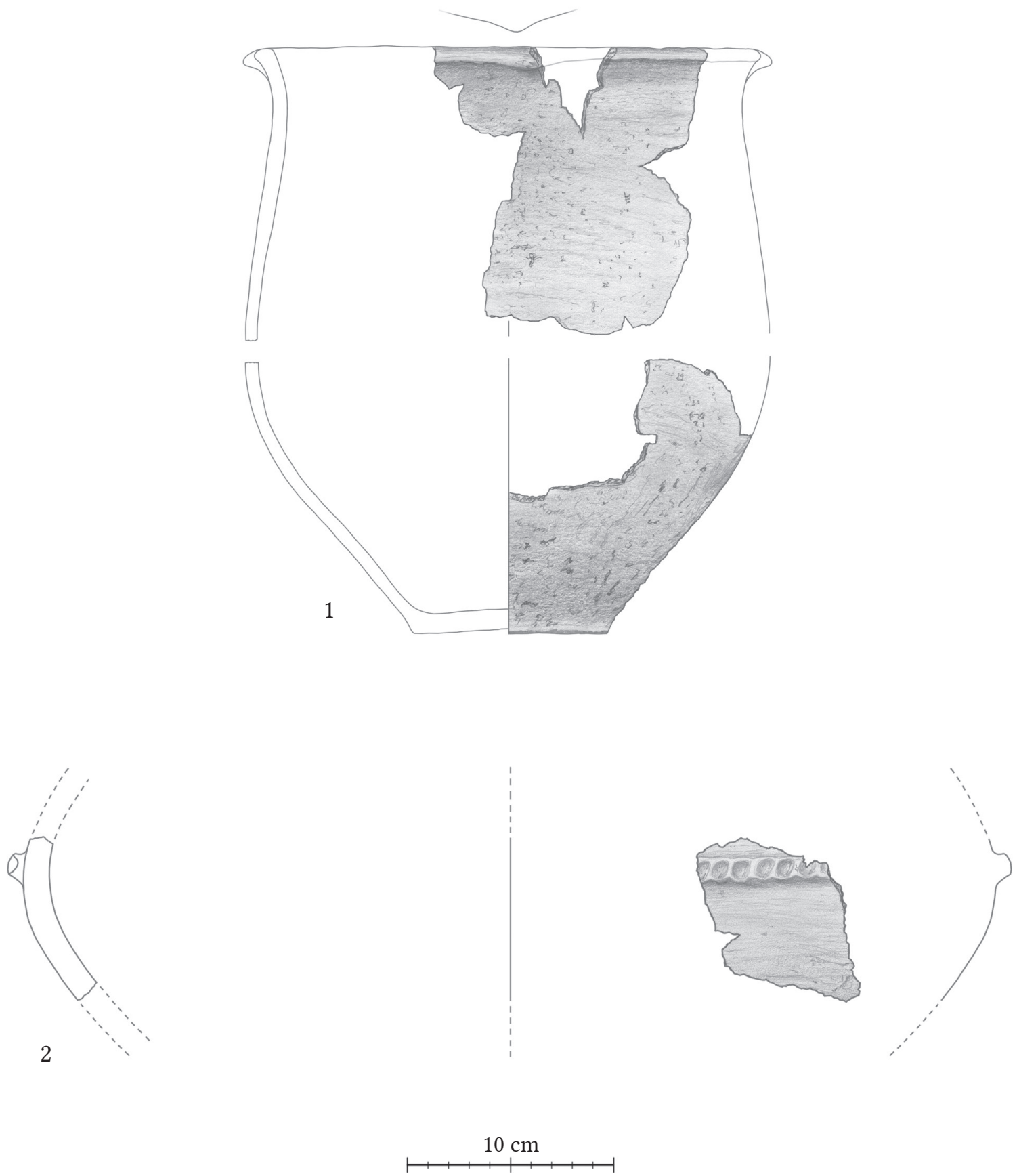

Fig. 34. Vessels from Feature 80. 1 - Vessel 25, 2 - Vessel 69 (Drawings: László Gucsi). 

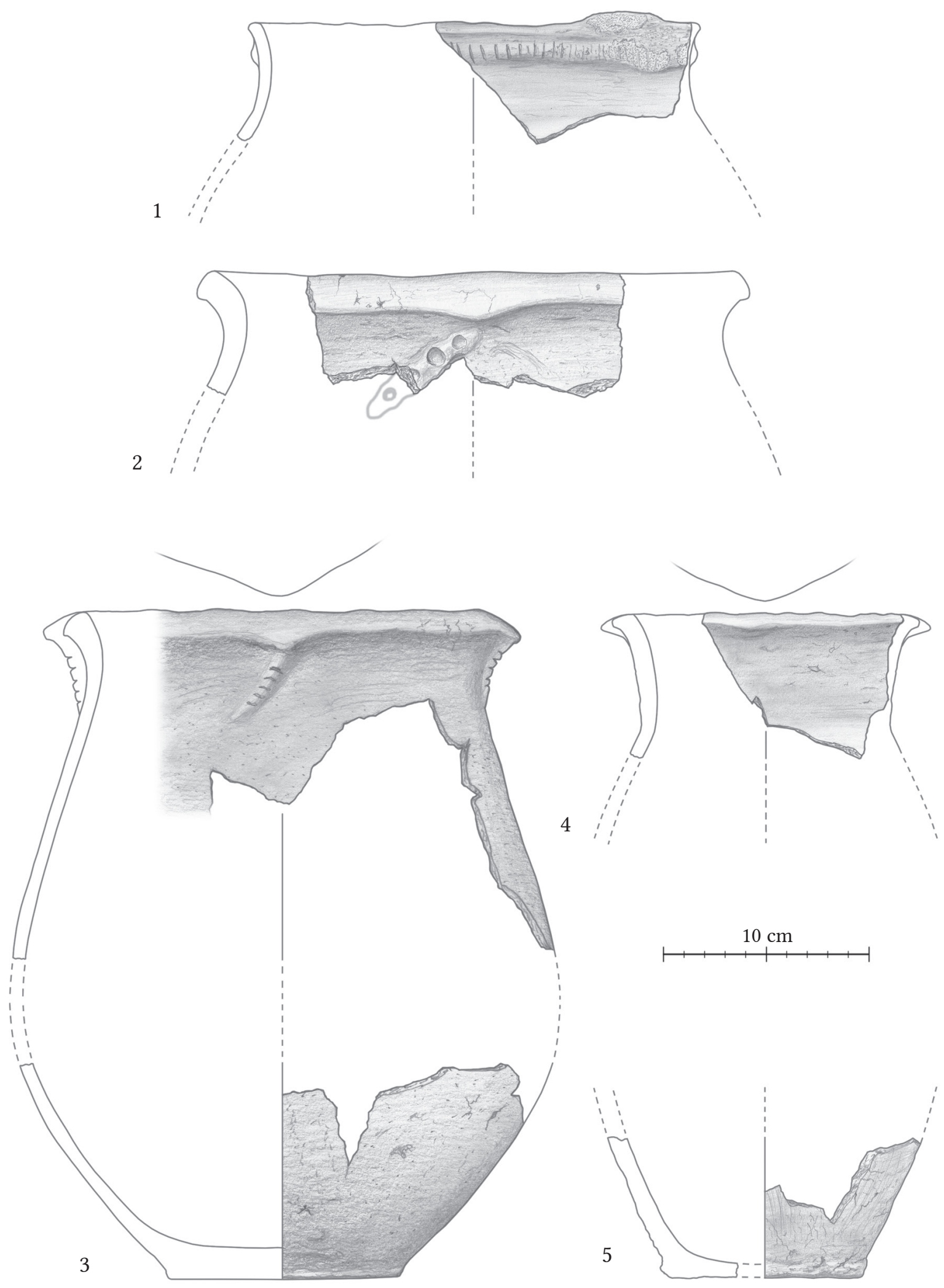

Fig. 35. Vessels from Feature 80. 1 - Vessel 30, 2 - Vessel 28, 3 - Vessel 26, 4 - Vessel 31, 5 - Vessel 32 (Drawings: László Gucsi). 

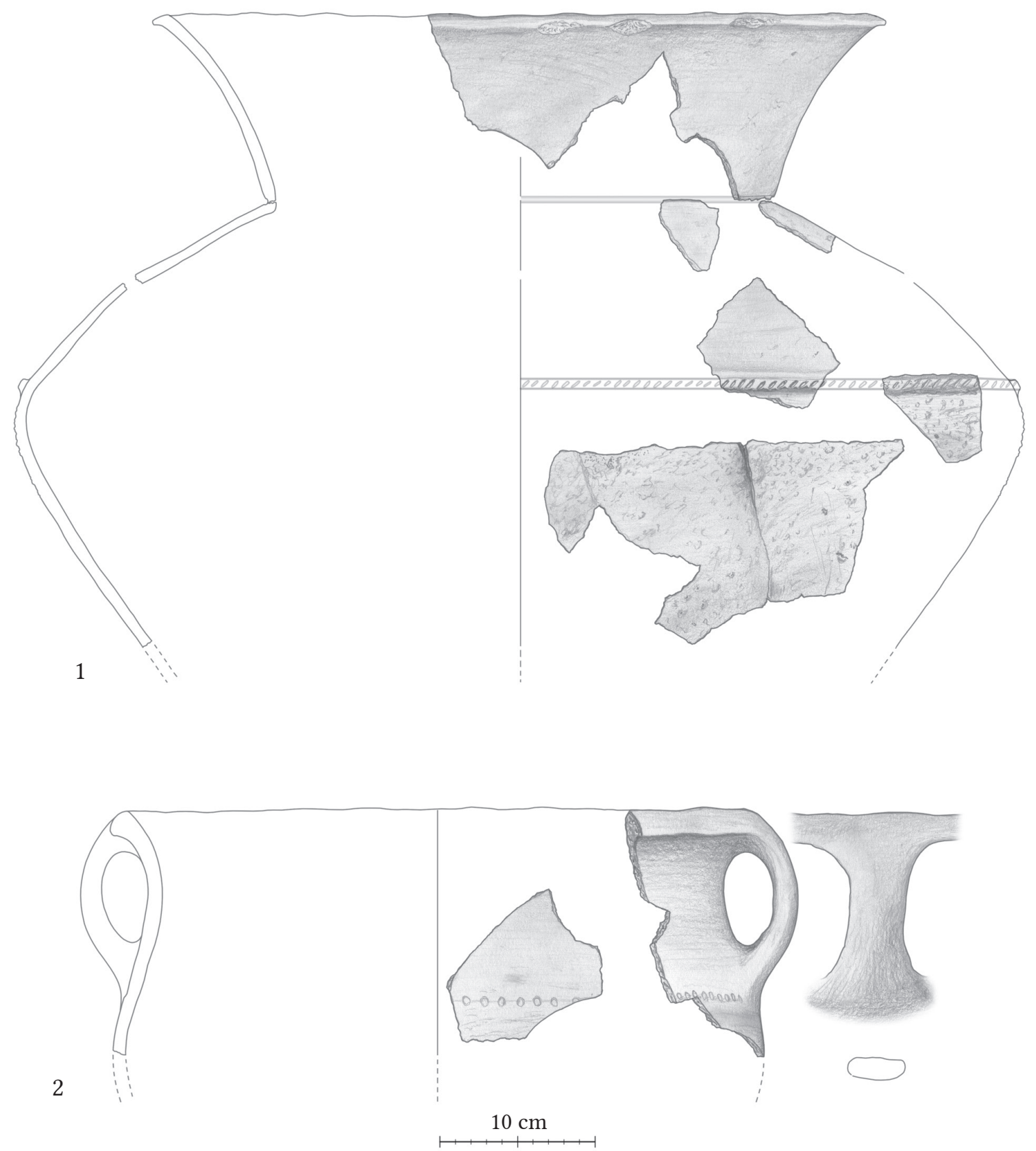

Fig. 36. Vessels from Feature 80. 1 - Vessel 70, 2 - Vessel 38 (Drawings: László Gucsi). 


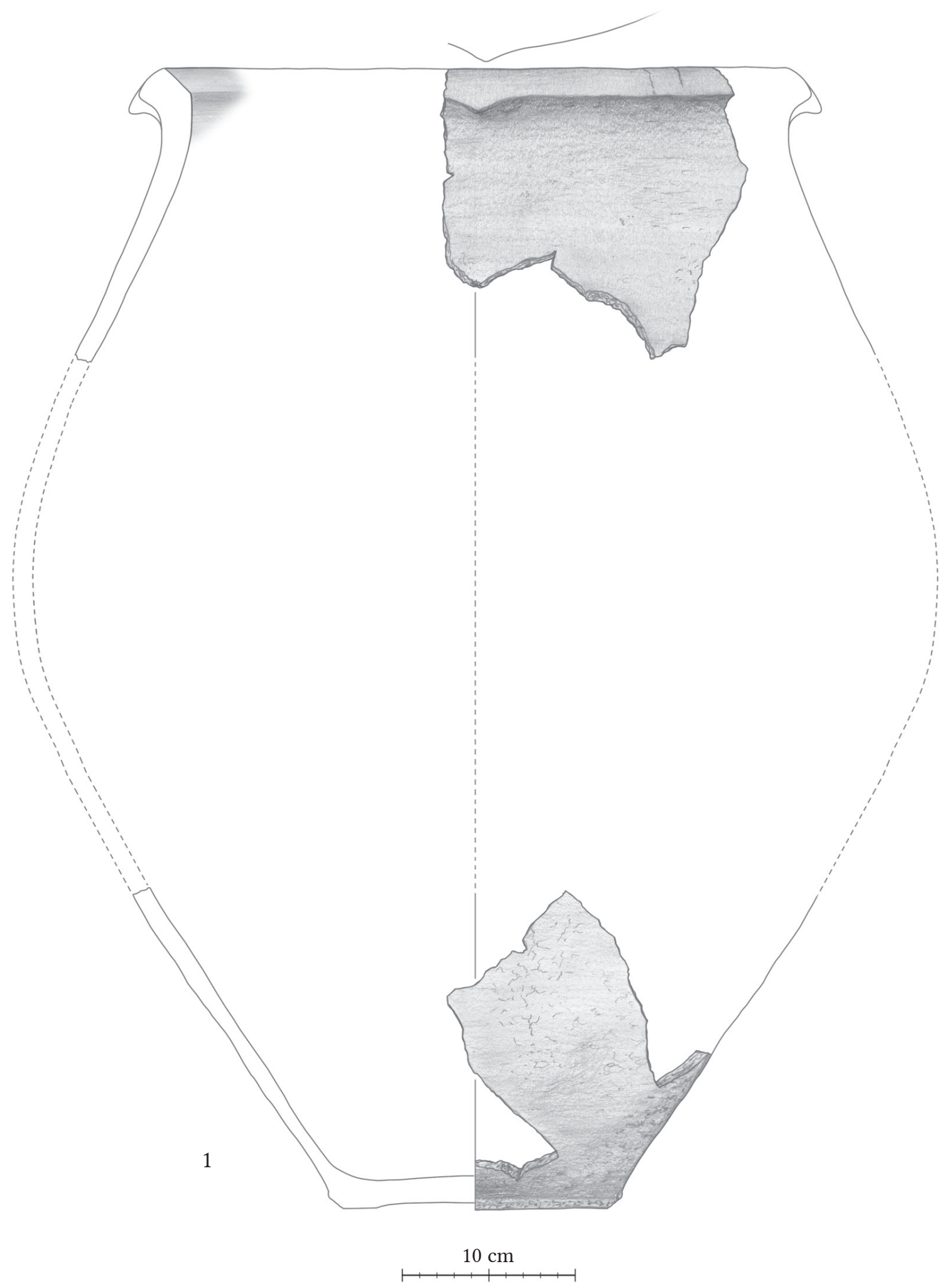

Fig. 37. Vessels from Feature 80. 1 - Vessel 27 (Drawings: László Gucsi). 


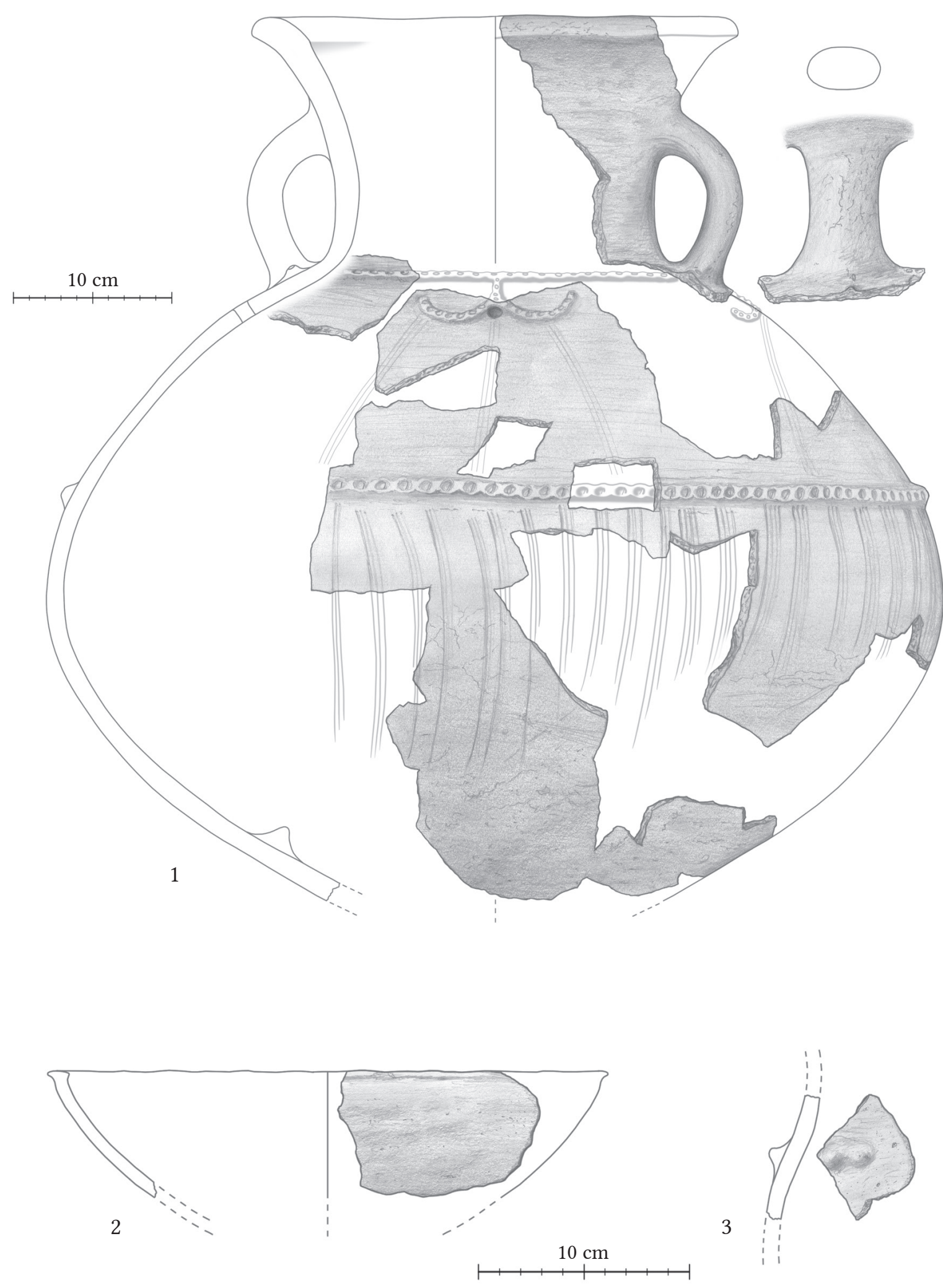

Fig. 38. Vessels from Feature 80. 1 - Vessel 72, 2 - Vessel 22, 3 - Vessel 23 (Drawings: László Gucsi). 

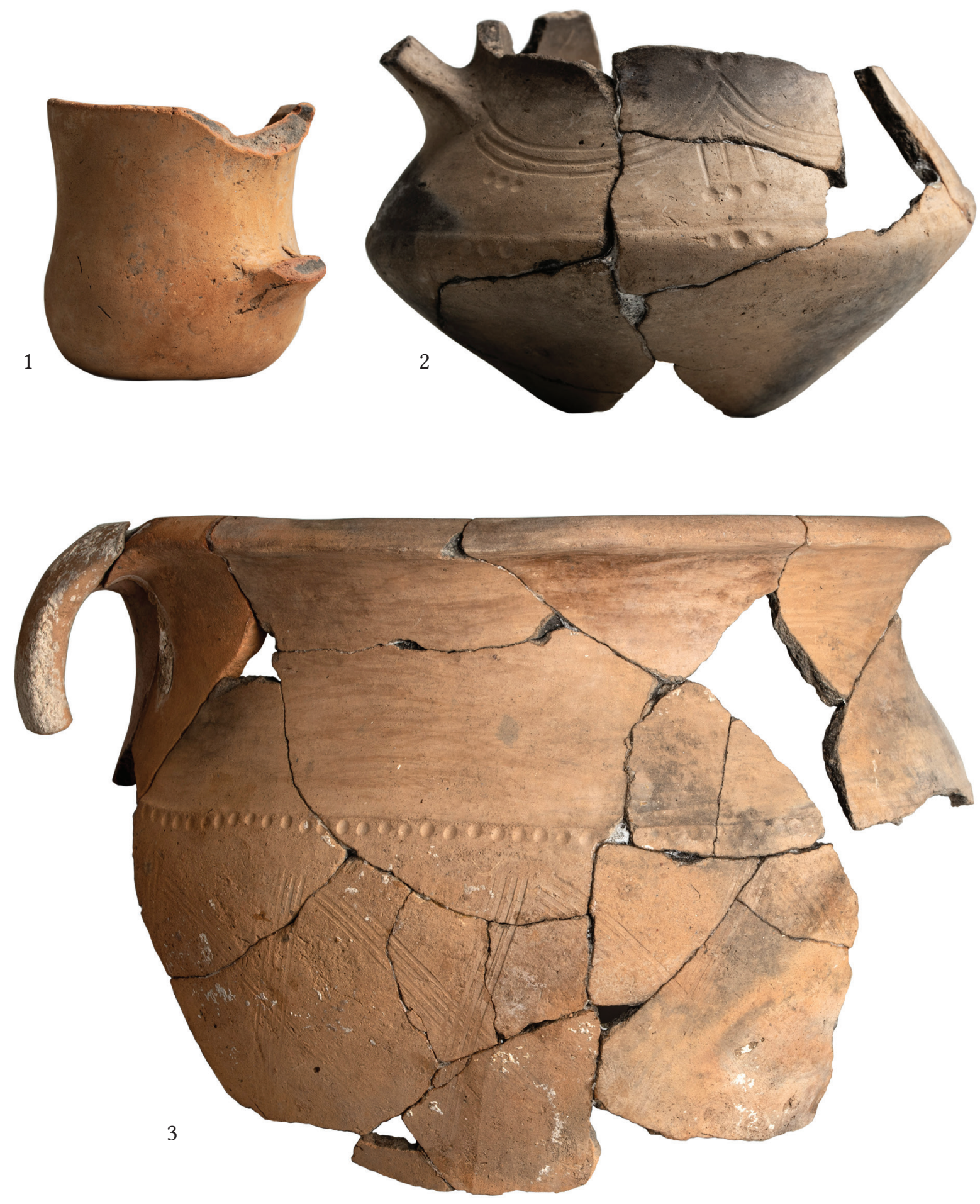

Fig. 39. Vessels from Feature 80. 1 - Vessel 1, 2 - Vessel 6, 3 - Vessel 35 (Photos: Nóra Szilágyi). 

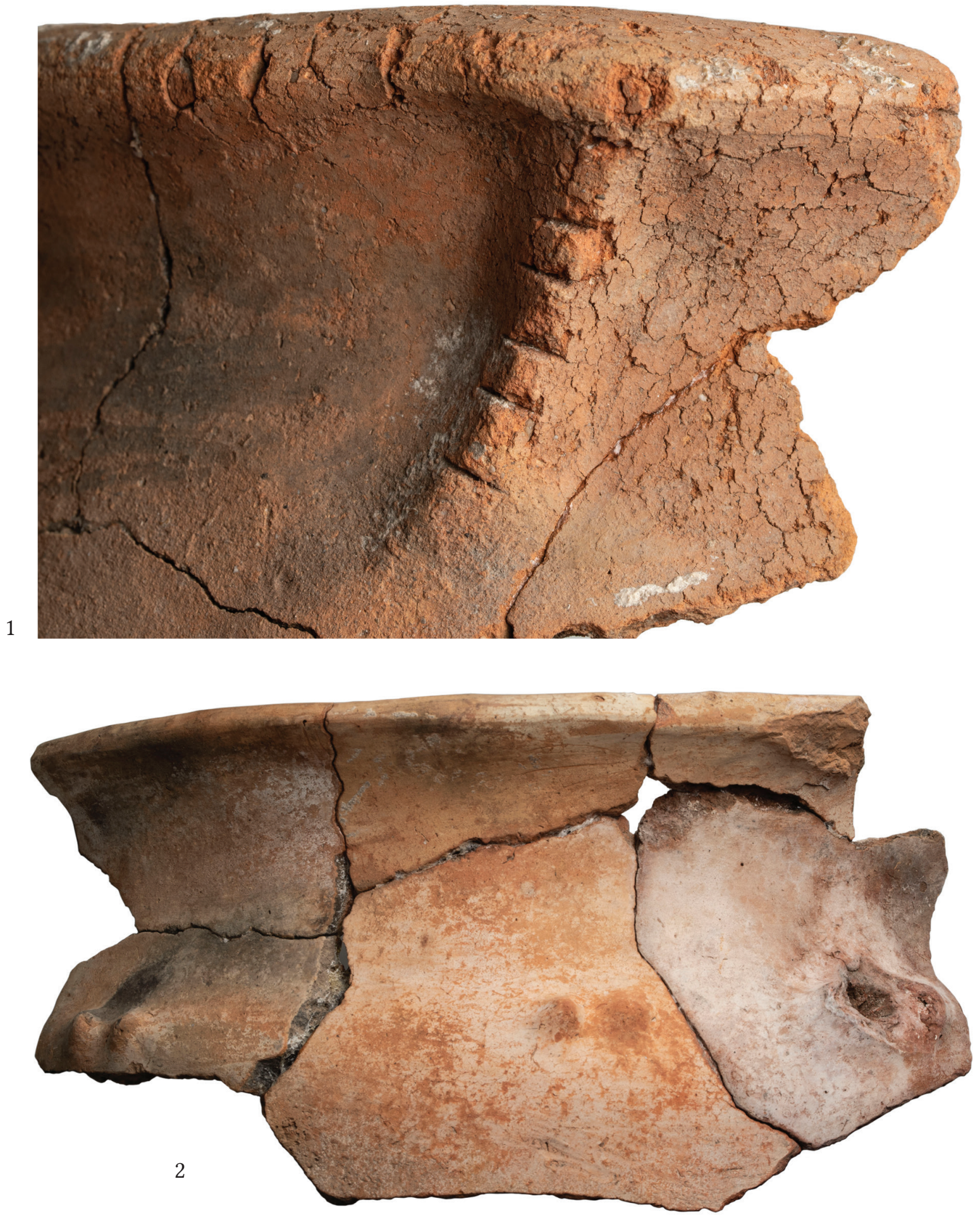

Fig. 40. Vessels from Feature 80. 1 - Vessel 26, 2 - Vessel 34 (Photos: Nóra Szilágyi). 

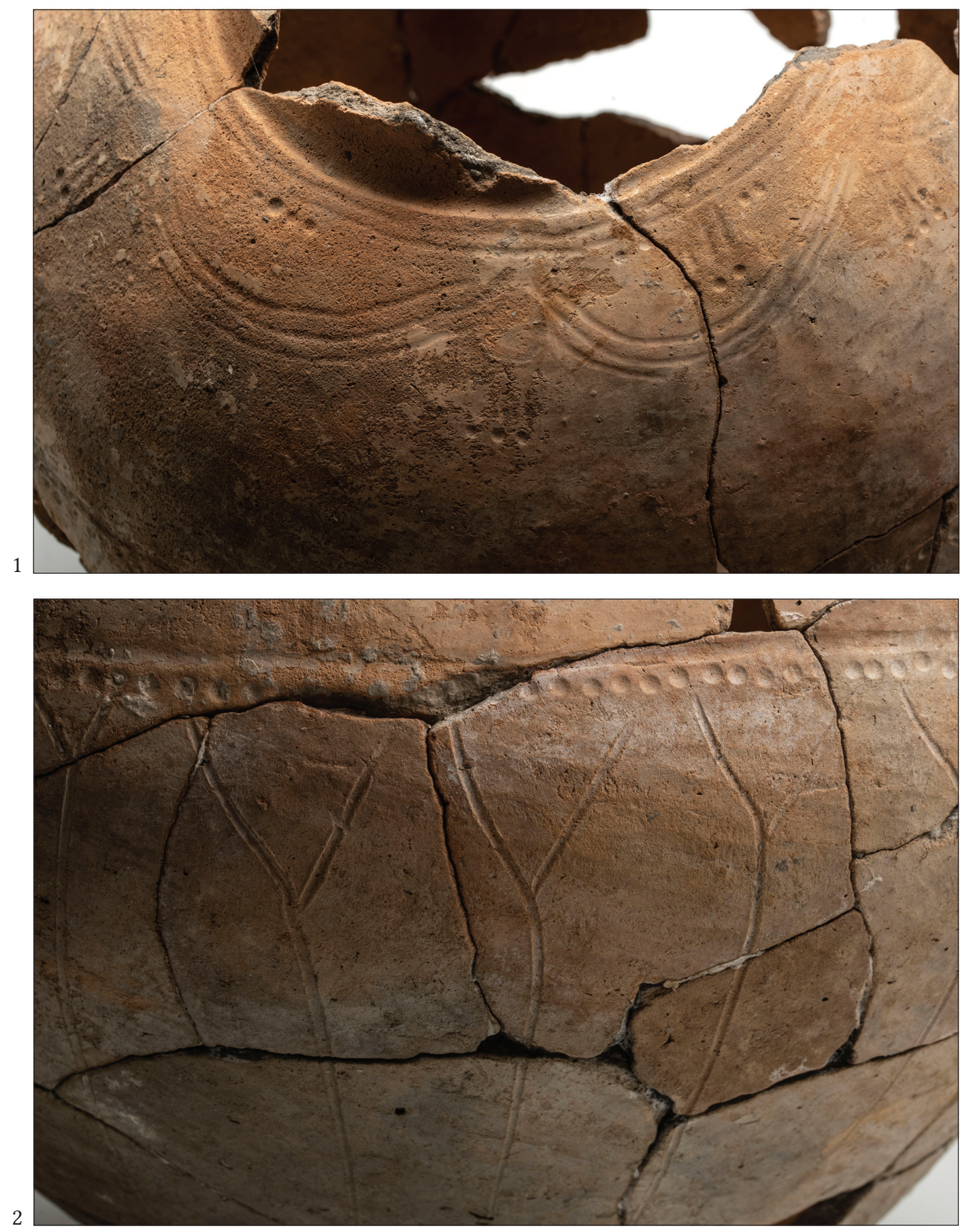

Fig. 41. 1-2 - Details of Vessel 42 from Feature 80 (Photos: Nóra Szilágyi). 
